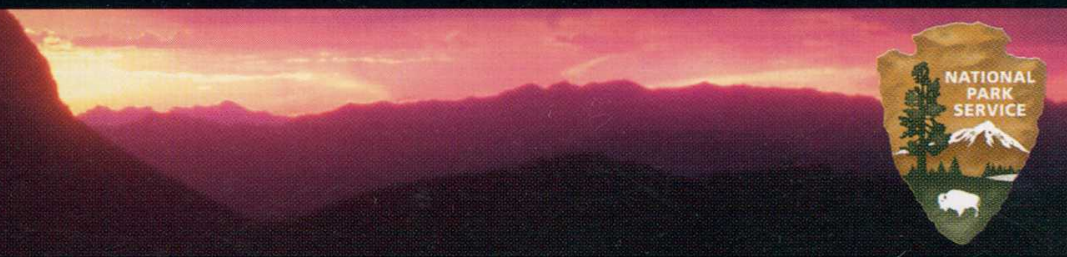

In Cooperation with the University of Arizona, School of Natural Resources

\title{
Vascular Plant and Vertebrate Inventory of Fort Bowie National Historic Site
}

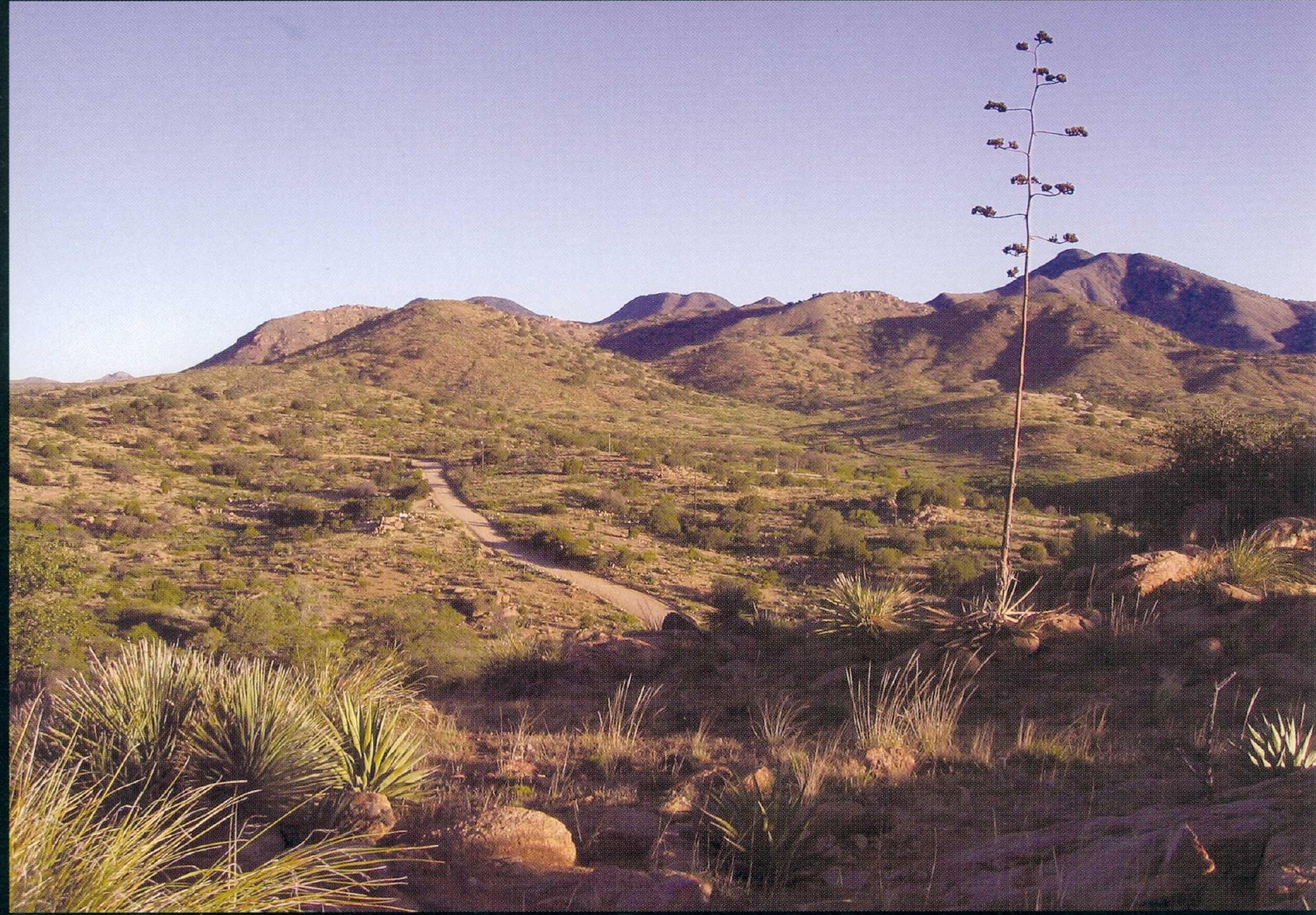

Southwest Biological Science Center

Open-File Report 2005-1167

February 2007

U.S: Department of the Interior

U.S. Geological Survey

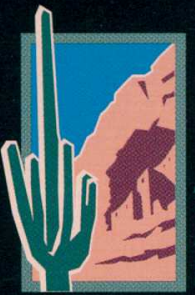

National Park Service 
? 


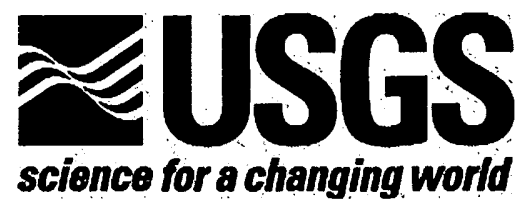

In cooperation with the University of Arizona, School of Natural Resources

\section{Vascular Plant and Vertebrate Inventory of Fort Bowie National Historic Site}

By Brian F. Powell, Cecilia A. Schmidt, and William L. Halvorson

Open-File Report 2005-1167

December 2006

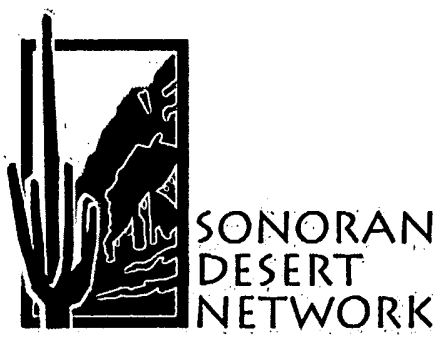

Inventory and Monitoring Program

U.S. Department of the Interior

U.S. Geological Survey

National Park Service
USGS Southwest Biological Science Center Sonoran Desert Research Station University of Arizona School of Natural Resources 125 Biological Sciences East Tucson, Arizona 85721 


\section{U.S. Department of the Interior \\ DIRK KEMPTHORNE, Secretary}

\section{U.S. Geological Survey}

Mark Myers, Director

U.S. Geological Survey, Reston, Virginia: 2006

For product and ordering information:

World Wide Web: http://www.usgs.gov/pubprod

Telephone: 1-888-ASK-USGS

For more information on the USGS-the Federal source for science about the Earth, its natural and living resources, natural hazards, and the environment:

World Wide Web:http://www.usgs.gov

Telephone: 1-888-ASK-USGS

\section{Suggested Citation}

Powell, B. F, C. A. Schmidt, and W. L. Halvorson. 2006. Vascular Plant and Vertebrate Inventory of Fort Bowie National Historic Site. USGS Open-File Report 2005-1167. U.S. Geological Survey, Southwest Biological Science Center, Sonoran Desert Research Station, University of Arizona, Tucson, AZ.

Cover photo: Ruins of the original military fort, Fort Bowie National Historic Site, Arizona. Photograph by Brian Powell.

Any use of trade, product, or firm names is for descriptive purposes only and does not imply endorsement by the U.S. Government. 


\section{Authors}

Brian F. Powell \& Cecilia Schmidt

School of Natural Resources

125 Biological Sciences East, Building 43

The University of Arizona

Tucson, AZ 85721

William L. Halvorson

USGS SBSC Sonoran Desert Research Station

125 Biological Sciences East, Building 43

The University of Arizona

Tucson, AZ 85721

\section{U.S. Geological Survey SBSC Sonoran Desert Research Station Personnel}

Charles van Riper III, Station Leader

William L. Halvorson, Research Ecologist

Cecil R. Schwalbe, Ecologist

Michael R. Kunzmann, Ecologist (Emeritus)

Kathryn Thomas, Ecologist

Pamela Nagler, Physical Scientist

Phil Rosen, Ecologist

\section{Program and Expertise Areas of USGS and UA Personnel}

Administration \& Outreach

Cori Dolan

Jennifer Meador

Wendy Parrish

Emily Sherbrooke

Charles van Riper III

Avian Ecology

Claire Crow

Glenn Johnson

Chris O'Brien

Brian Powell

Charles van Riper III

Data Management

Brent Sigafus

Ecology of Amphibians \& Reptiles

Kevin Baker

Cristina Jones

Dave Prival

Phil Rosen

Cecil Schwalbe

Brent Sigafus

\author{
Fire Management \\ Dennis Suhre \\ Cori Dolan \\ James Feldmann \\ Bill Halvorson \\ Invasive Species Research \\ Patricia Guertin \\ Jim Malusa \\ Phil Rosen \\ Cecil Schwalbe \\ Brent Sigafus \\ Dennis Suhre \\ Kathryn Thomas \\ Inventory \& Monitoring \\ Patricia Guertin \\ Bill Halvorson \\ Pamela Nagler \\ Brian Powell \\ Cecilia Schmidt \\ Vegetation Mapping \& Ecology \\ Patricia Guertin \\ Bill Halvorson \\ Jim Malusa \\ Kathryn Thomas
}

USGS Southwest Biological Science Center http://sbsc.wr.usgs.gov

USGS Southwest Biological Science Center, Sonoran Desert Research Station http://sbsc.wr.usgs.gov/sdrs 

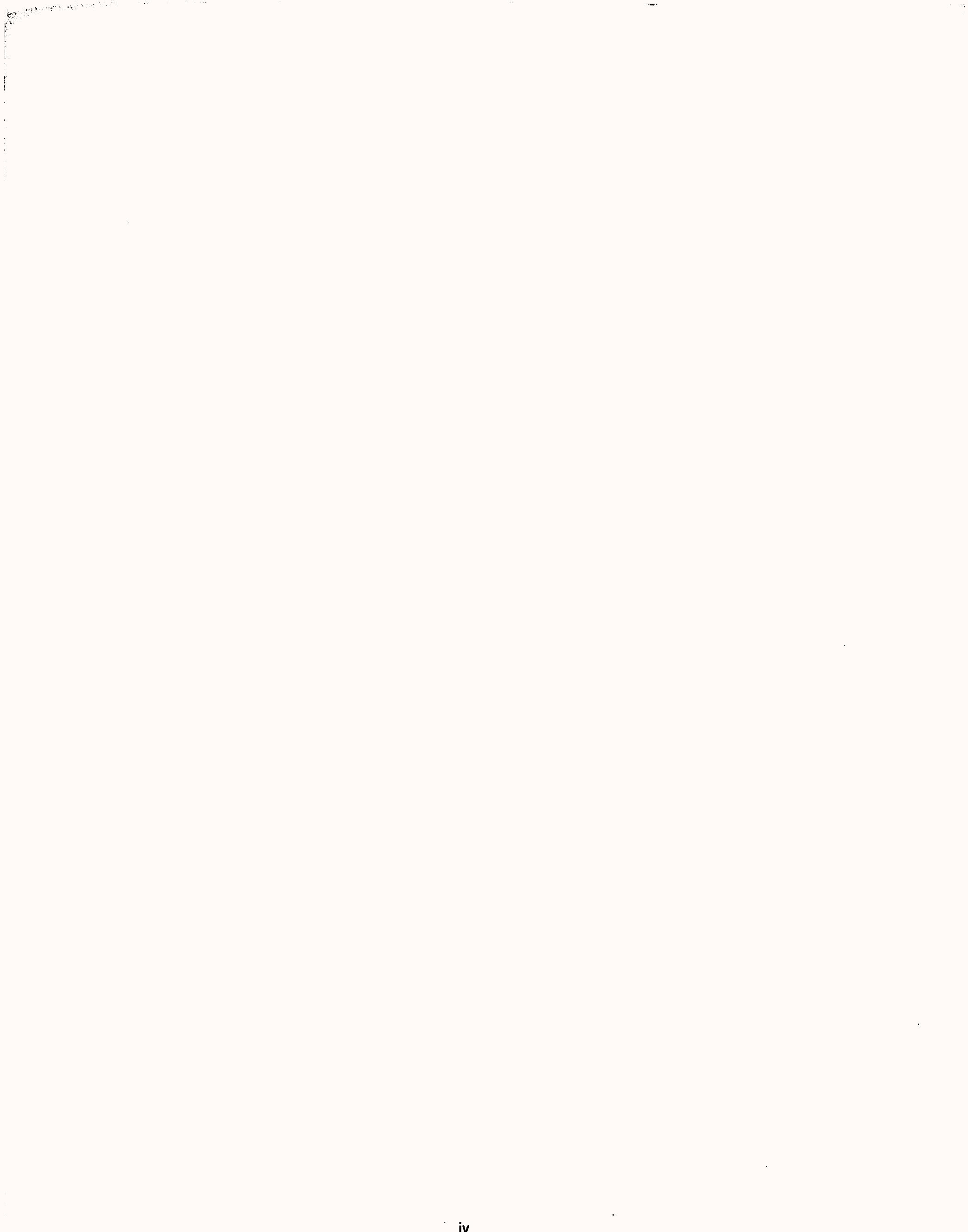

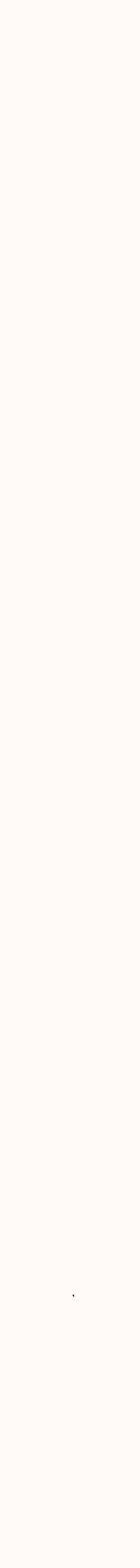




\section{Table of Contents}

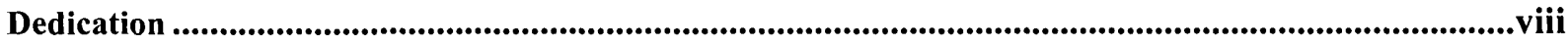

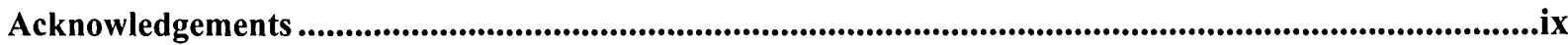

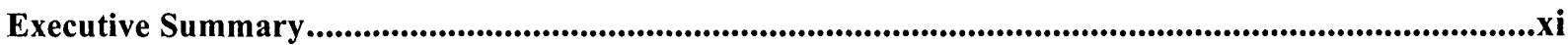

Chapter 1: Introduction to the Biological Inventories....................................................................................1

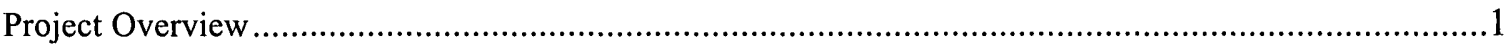

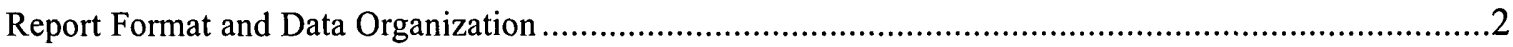

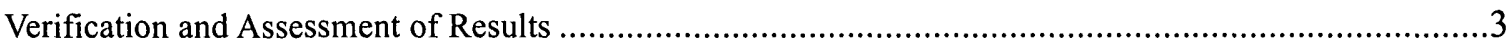

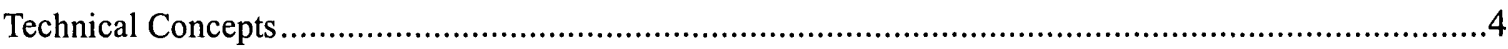

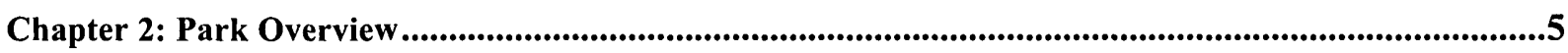

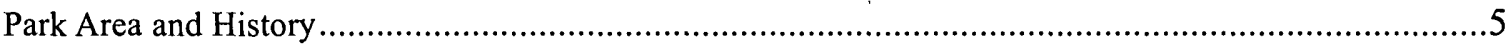

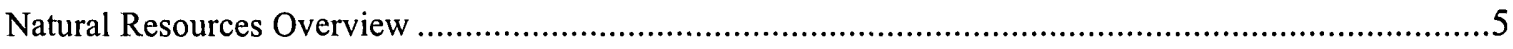

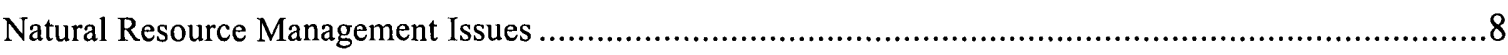

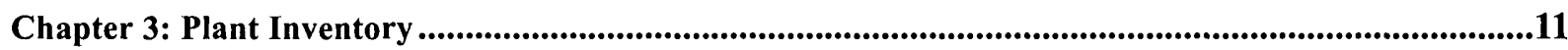

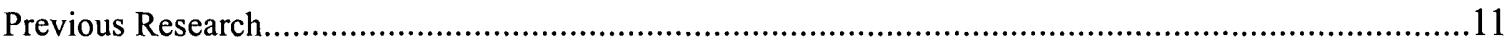

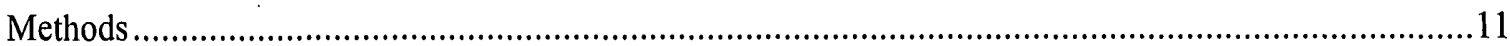

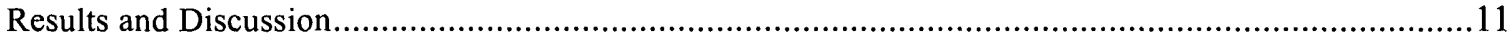

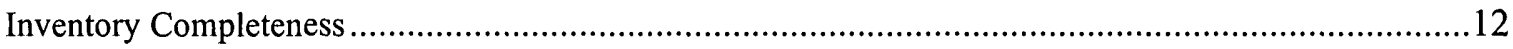

Chapter 4: Bird Inventory

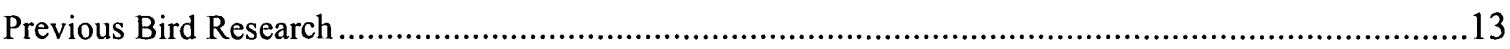

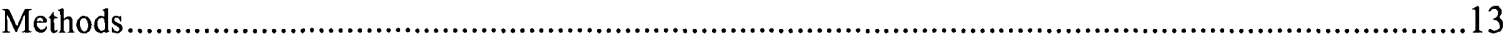

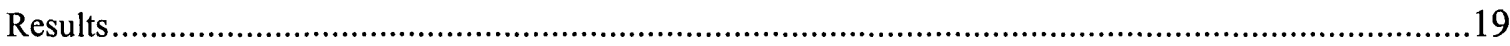

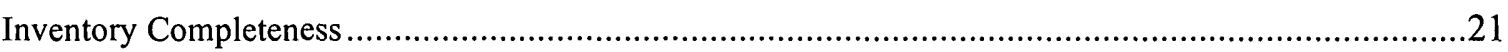

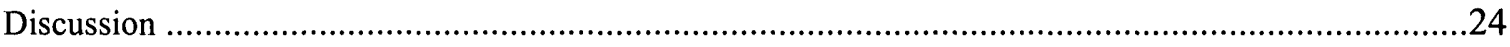

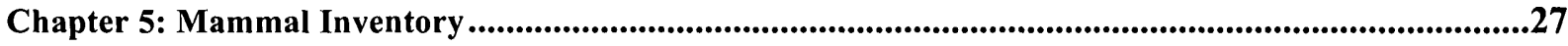

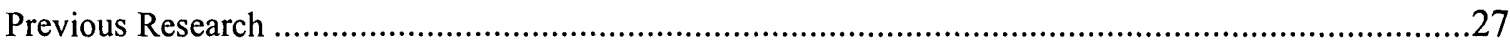

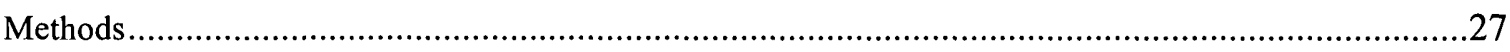

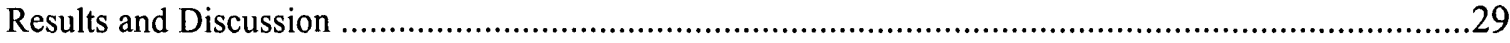

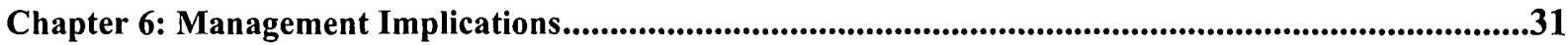

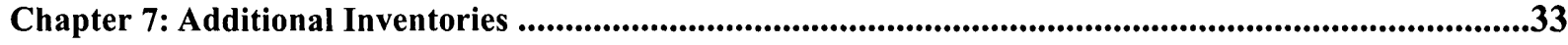

Chapter 8: Literature Cited ..............................................................................................................................35 


\section{List of Tables}

Table 1. Summary results of plant and vertebrate inventories at Fort Bowie NHS, 2002 to 2004..................

Table 1.1. Museums that were queried in 1998 for vertebrate voucher specimens with "Arizona" and "Fort Bowie National Historic Site" in the collection location. .............................................

Table 2.1. Average monthly climate data for Bowie, Arizona, 1899-2004. .........................................5

Table 4.1. Mean density (ha) of the most common tree species at each station along the two VCP

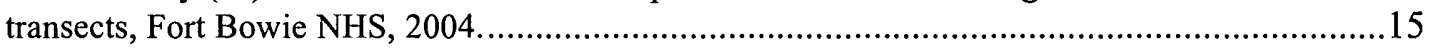

Table 4.2. Summary of bird survey effort, Fort Bowie NHS, 2002-2004..............................................15

Table 4.3. Total number of observations (Total obs.) and relative abundance (mean $\pm \mathrm{SE}$ ) of birds during VCP surveys, Siphon Canyon transect, Fort Bowie NHS, 2003 and 2004........................20

Table 4.4. Total number of observations (Total obs.) and relative abundance (mean $\pm \mathrm{SE}$ ) of birds during VCP surveys, Butterfield transect, Fort Bowie NHS, 2004.

Table 4.5. Relative abundance of birds observed during line-transect surveys, Fort Bowie NHS, 2002 and 2003

Table 4.6. Number of observations by breeding behavior for birds, Fort Bowie NHS, 2003 and 2004.

Table 5.1. Summary of Trailmaster camera effort, Fort Bowie NHS, 2002 and 2003.

Table 5.2. Number of photographs of animals, by Trailmaster camera site, Fort Bowie NHS, 2002 and 2003

\section{List of Figures}

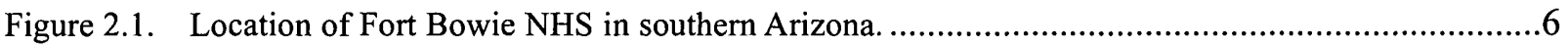

Figure 2.2. Aerial photograph of Fort Bowie NHS showing some of the major features..............................7

Figure 2.3. Comparison of monthly weather data during the time of the inventory (2002-2004) compared to the long-term mean (1899-2004), Bowie, Arizona. ................................................

Figure 4.1. Photographs taken from bird survey stations, Fort Bowie NHS. .........................................14

Figure 4.2. Locations of bird surveys, Fort Bowie NHS, 2002-2004...................................................16

Figure 4.3. Species accumulation curves, by survey type, for the UA inventory effort, Fort

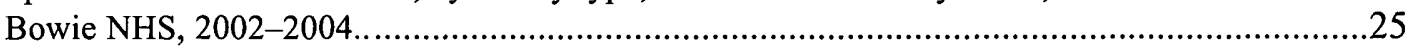

Figure 5.1. Location of Trailmaster camera sites, Fort Bowie NHS, 2002-2003....................................27

Figure 5.2. Diagram of infrared-triggered camera (Trailmaster) set-up. .................................................28 


\section{List of Appendices}

Appendix A. Plant species that were observed or collected at Fort Bowie NHS by the University of Arizona inventory personnel (UA; 2002 and 2003) and other studies:

Appendix B. Amphibians and reptiles observed or documented at Fort Bowie NHS by University of Arizona (UA) personnel, Swann et al. (2001; Swann), and Lowe and Johnson (1976; L\&J) and from voucher specimens reported in Appendix E (AE).

Appendix C. Number of observations of bird species, by detection type, at Fort Bowie NHS by University of Arizona (UA) inventory personnel, 2002-2004.

Appendix D. Mammals recorded at Fort Bowie NHS by University of Arizona inventory personnel (UA) and/or documented/observed by other researchers or located in the UA mammal collection

Appendix E. List of voucher specimens collected from Fort Bowie NHS

Appendix F. Summary of vegetation characteristics measured at bird survey stations, Fort Bowie NHS, 2004.

Appendix G. Most abundant bird species at each transect and season based on data published in Russell and Johnson (1976) and the UA inventory. .78

Appendix H. Number of Trailmaster photos and total number of individuals of each species. . .80

Appendix I. Photographic vouchers taken by University of Arizona inventory personnel, Fort Bowie NHS 2002-2004. 


\section{Dedication}

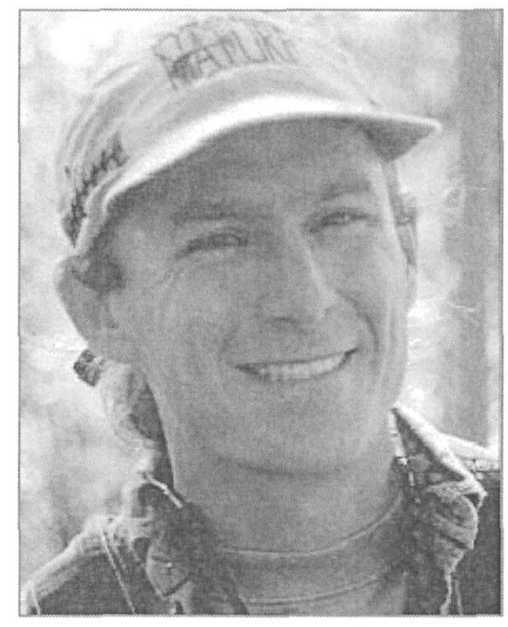

\section{Eric Wells Albrecht}

1970-2004

This report, as others in this series, is dedicated to Eric's life and work; he was an extraordinary ecologist, community member, father, and partner. Eric was co-coordinator of the University of Arizona (UA) biological inventory and monitoring program from 2002 until his sudden and unexpected death on September 20, 2004. Eric was near completion of his MS degree in Wildlife Conservation from the UA, which was awarded posthumously in November 2004. In his last year, Eric spearheaded projects to investigate the efficiency of current monitoring programs; he was passionate about using the best available information to guide vertebrate monitoring efforts in the region. He is survived by his partner, Kathy Moore, and their two young children, Elizabeth and Zachary. We hope that the lives of his children will be enriched by Eric's hard work on behalf of the national parks in the Sonoran Desert Network. 


\section{Acknowledgements}

Thanks to Fort Bowie NHS staff members Larry Ludwig and Barbara Herman-Reese for their on-site support and Superintendent Alan Whalon, Chief of Resources Carrie Dennett, Biological Technician Ruth Olsen, and all the staff at Chiricahua National Monument for their administrative support of our program. This project resulted from the collaboration of many people at the U.S. Geological Survey (USGS), University of Arizona (UA) and the National Park Service (NPS), and was facilitated by the Desert Southwest and Colorado Plateau Cooperative Ecosystem Studies Units (CESUs). The project was funded by the National Park Service Natural Resource Challenge Program. The Southern Arizona Office of NPS facilitated development of the original study plan that led directly to initiation of this project. Andy Hubbard, Network Coordinator of the Sonoran Desert Network (SDN) Inventory and Monitoring (I\&M) program, has been a strong and convincing advocate for continuing the role of the USGS/UA Inventory program in the I\&M program. Kathy Davis at Tuzigoot and Montezuma Castle national monuments played an instrumental role in this project by providing important early initiative. Larry Norris at the Desert Southwest CESU has provided strong support for our program and spent considerable time and effort providing clear and timely administrative assistance. Matt Goode, Don Swann, and Dale Turner provided much of the early planning for this project; we are indebted to their vision. Special thanks to Lisa Carder and Kathleen Docherty for their years of hard work on all aspects of the project. Eric Albrecht, to whom this report is dedicated, was an outstanding spokesperson and leader of the program; he was an invaluable member of the team and his contributions are sorely missed.

We thank a core group of dedicated field biologists who collected a wealth of data at Fort Bowie NHS: James MacAdam, and Meg Quinn (plants); Eric Albrecht, Gabe Martinez, and Janine McCabe (birds); and Patina Thompson (mammals). Barbara Herman-Reese provided Trailmaster data. We are appreciative of the following people, whose work in the office made the field effort more successful: Debbie Angell, Jennifer Brodsky, Brian Cornelius, Taylor Edwards, Carianne Funicelli, Marina Hernandez, Colleen McClain, Heather McClaren, Lindsay Norpel, Ryan Reese, Jill Rubio, Brent Sigafus, Taffy Sterpka, Jenny Treiber, and Alesha Williams.

Additional administrative support was provided by Valery Catt at the USGS Sonoran Desert Research Station and Terri Rice, Andy Honaman, Jenny Ferry, and especially Cecily Westphal of the School of Natural Resources at the UA. Technical support was graciously given by the following experts: Dan Austin, Michael Chamberland, Phil Jenkins, and Charlotte and John Reeder at the UA Herbarium; Tom Huels of the UA ornithology collection. Thanks to Sharon Megdal and Peter Wierenga, the current and former directors, respectively, of the UA Water Resources Research Center, and all their staff.

We received helpful reviews of an earlier version of this report by: Carrie Dennett, Dennis Fenn, Michele Girard, Andy Hubbard, Larry Laing, Theresa Mau-Crimmons, Larry Norris, Ruth Olsen, and Alan Whalon. All mistakes or omissions are the responsibility of the authors. 


\section{Executive Summary}

This report summarizes results of an inventory of plants, birds, and mammals of Fort Bowie National Historic Site (NHS) in southeastern Arizona. Surveys at the park were part of a larger effort to inventory vascular plants and vertebrates in eight National Park Service (NPS) units in Arizona and New Mexico. Our inventory efforts build on past research for the park; included in this report is the most comprehensive synthesis of species lists from past studies of plants and vertebrates. Though we did not survey specifically for them, we also include a species lists of amphibians and reptiles that have been observed or documented at the park.

For a park of its size (405 ha), Fort Bowie NHS has extraordinary species richness, especially for plants (638 species) and mammals (57 species). This diversity results from its geographic location at the junction of three biogeographical provinces, its diverse geology, and the presence of year-round water from an active spring.
We found 45 new plant and vertebrate species for the park (Table 1) including:

- Plants: two species representing new families and nine species representing new genera, including one new genus (Euphorbia) represented by three species; - Birds: zone-tailed hawk and common ground dove;

- Mammals: domestic dog and hooded skunk.

Based on a review of past studies and our own work, we consider the inventories of plants and vertebrates to be $90 \%$ complete. With baseline inventories at Fort Bowie NHS among the most complete of the 11 parks in the Sonoran Desert Network, park staff are now in an excellent position to monitor changes in these resources.

Table 1. Summary results of plant and vertebrate inventories at Fort Bowie NHS, 2002 to 2004.

\begin{tabular}{lcccc}
\hline & \multicolumn{4}{c}{ UA Effort } \\
\cline { 2 - 5 } Taxonomic group & $\begin{array}{c}\text { Number of } \\
\text { species recorded }\end{array}$ & $\begin{array}{c}\text { Number of } \\
\text { non-native species }\end{array}$ & $\begin{array}{c}\text { Number of new species } \\
\text { added to park lista }\end{array}$ & $\begin{array}{c}\text { Total number of } \\
\text { species on park listb }\end{array}$ \\
\hline Plants & 193 & 13 & 33 & 638 \\
\hline Amphibians and Reptiles & 8 & 0 & 0 & 40 \\
\hline Birds & 109 & 0 & 6 & 189 \\
\hline Mammals & 14 & 1 & 2 & 59 \\
\hline Totals & 324 & 14 & 41 & 926 \\
\hline
\end{tabular}

${ }^{a}$ Species that had not been observed or documented by previous studies.

${ }^{b}$ From all sources (see Appendices A-D for complete lists). 


\section{Chapter 1: Introduction to the Biological Inventories}

\section{Project Overview}

\section{Inventory: A point-in-time effort to document the resources present in an area.}

In the early 1990 s, responding to criticism that it lacked basic knowledge of natural resources within parks, the National Park Service (NPS) initiated the Inventory and Monitoring Program (NPS 1992). The purpose of the program is to increase scientific research in NPS units and to detect long-term changes in biological resources (NPS 1992). At the time of the program's inception, basic biological information, including lists of plants and animals, were absent or incomplete for many parks (Stohlgren et al. 1995).

Species inventories have both direct and indirect value for management of the park. Species lists facilitate resource interpretation and visitor appreciation of natural resources.

Knowledge of which species are present, particularly sensitive species, and where they occur is critical for making management decisions (e.g., locating new facilities). Inventories are also a cornerstone of long-term monitoring. Thorough biological inventories provide a basis for choosing parameters to monitor and can provide initial data (i.e., a baseline) for monitoring ecological populations and communities. Inventories can also test sampling strategies, field methods, data collection protocols, and provide estimates of variation that are essential in prospective power analysis.

\section{Goals}

The purpose of this study was to complete basic inventories for vascular plants, birds, and mammals at Fort Bowie National Historic Site (NHS). This effort was part of a larger biological inventory of eight NPS units in southern Arizona and southwestern New Mexico (Davis and Halvorson 2000, Powell et al. 2003, 2004, 2005a). The results presented in this report supersede those reported by Powell et al. (2003, 2004, and 2005b).
The goals of our biological inventory of

Fort Bowie NHS were to:

1. Conduct field surveys to bring the current species lists for vascular plants, birds, and mammals to at least $90 \%$ of the species expected to occur at the park.

2. Use repeatable sampling designs and survey methods (when appropriate) that allow estimation of parameters of interest with associated estimates of precision.

3. Compile historic occurrence data for plants and vertebrates (including amphibians and reptiles) from three sources: museum records (specimen vouchers), previous studies, and park records.

4. Create resources useful to park managers, including detailed species lists, maps of study sites, and high-quality digital images for use in resource interpretation and education.

The bulk of our effort addressed goals number 1 and 2. To maximize efficiency (i.e., the number of species recorded by effort) we used field techniques designed to detect multiple species. We did not undertake single-species surveys for threatened or endangered species.

\section{Administrative History}

The original study plan for this project was developed, and an inventory of one Sonoran Desert Network (SDN) park (Tumacácori National Historical Park) was completed, through a cooperative agreement between NPS, UA, and the USGS. This project comprises biological inventories for seven additional parks and was funded through Task Agreements UAZ-03, -05, -06, and -07 (under Colorado Plateau CESU cooperative agreement number 1200-99-009). The National Park Service thereafter obligated additional funds for administration, management, and technical oversight of the biological inventories through the Colorado Plateau CESU (UAZ-07) and the Desert Southwest CESU (cooperative agreement number CA 1248-00002 , reference UAZ39, $-77,-87,-97$, and 128). 


\section{Report Format and Data Organization}

This report includes summaries and analyses of data related to vascular plants, birds, and mammals collected from 2002 to 2004 at Fort Bowie NHS. This report is intended to be useful in internal planning processes and outreach and education, and as such we strive to make it relevant, easy to read, and well organized. We report only common names (listed in phylogenetic sequence) unless the species is not listed later in an appendix; in this case we present both common and scientific names. For each taxonomic group we include an appendix of all species that we recorded at the park (Appendices A, C, and D). Although we did not survey specifically for amphibians and reptiles, we made a few incidental observations and we include a list of species observed or documented by others (Appendix B). Species lists are in phylogenetic sequence and include taxonomic order, family, genus, species, subspecies or varieties (if applicable) and common name. Scientific and common names used throughout this document are current according to accepted authorities for each group: Integrated Taxonomic Information System (ITIS 2004) and the PLANTS database (USDA 2004; including designation of plants as "non-native") for plants; Stebbins (2003) for amphibians and reptiles; American Ornithologist Union (AOU 1998, 2003) for birds; and Baker et al. (2003) for mammals. To maintain consistency throughout the document, we do not capitalize the first letter of common names unless they are proper names. In this document we use the International System of Units for measurements.

\section{Previous Amphibian and Reptile Inventories}

We did not survey for amphibians and reptiles because there have been two thorough inventories for them: the first by Lowe and Johnson (1976) and more recently by Swann et al. (2001). In addition to re-surveying Lowe and Johnson's linetransects, Swann et al. set up long-term monitoring plots, surveyed road transects, and produced an annotated species list. In total, these studies found one non-native species (American bullfrog), and 31 reptile species (16 lizards, one turtle, and 14 snakes) including Texas horned lizard, a federally listed species of concern. The most notable species is now-extirpated Chiricahua leopard frog (a federally threatened species; HDMS 2004). In this report, we list the species found by these studies and species that our crews found while conducting surveys for other taxa (Appendix B). We also summarize specimens located in the University of Arizona herpetology collection (Appendix E), and a few photographic vouchers that we took during our course of other field research (Appendix I).

\section{Spatial Data}

Most spatial data are geographically referenced to facilitate mapping of study plots and locations of plants or animals. Coordinate storage is the Universal Transverse Mercator (UTM) projection, using North American datum 1983 (NAD 83), Zone 12. We recorded UTM coordinates using hand-held Garmin eMap ${ }^{\circledR}$ Global Positioning System (GPS) units (Garmin International Incorporated, Olathe, $\mathrm{KS}$; horizontal accuracy is about $10-30 \mathrm{~m}$ ). For each taxon-specific chapter of this document we mapped the location of all plots or stations overlaid on Digital Orthophoto Quarter Quads (DOQQ; produced by the U.S. Geological Survey). All studysite coordinates are stored at the same locations as for data archiving (below).

\section{Species Conservation Designations}

We indicate species conservation designations by the following agencies: U.S. Fish and Wildlife Service (responsible for administering the Endangered Species Act), Bureau of Land Management, U.S.D.A. Forest Service, Arizona Game and Fish Department, and Partners in Flight (a partnership of federal, state and local governments, non-governmental organizations, and private industry).

\section{Databases and Data Archiving}

We entered field data into taxon-specific databases (Microsoft Access version 97) and checked all data for transcription errors. From these databases we reproduced copies of the original field datasheets using the "Report" function in Access. The output looks similar to the original datasheets but data are easier to read. The databases, printouts, and other data such as digital photographs and GIS layers will be distributed to the park and to the University of Arizona, Special Collections (Main Library, Tucson). Original copies of all datasheets will be given to the NPS SDN I\&M program office in 
Tucson and may be archived at another location (most likely Western Archaeological Conservation Center, Tucson; Andy Hubbard, pers. comm.). This redundancy in data archiving is to ensure that these valuable data are never lost. Along with the archived data we will include copies of the original datasheets and a guide to filling them out. This information, in conjunction with the text of this report, should enable future researchers to repeat our work.

\section{Verification and Assessment of Results}

\section{Photographic Vouchers}

Whenever possible we documented vertebrate species with analog color photographs. Many of these photos show detail on coloration or other characteristics of visual appearance, and they may serve as educational tools for the park staff and visitors. Photographs will be archived with other data as described above.

\section{Specimen Vouchers}

With proper documentation, specimen vouchers are the most indisputable form of evidence of species occurrence. For plants, we searched the University of Arizona Herbarium for existing specimens from Fort Bowie NHS (see Appendix A for results), but we collected herbarium specimens whenever flowers or fruit were present on plants in the field (Appendix A). All specimens that we collected were accessioned into the University of Arizona Herbarium. Although we did not collect specimen vouchers for vertebrates, we searched for existing vouchers from Fort Bowie NHS in records from 23 natural history museums (Table 1.1 see Appendix E for results).

\section{Assessing Inventory Completeness}

We evaluated inventory completeness by (1) examining the rate at which new species were recorded in successive surveys (i.e., species accumulation curves; Hayek and Buzas 1997) and (2) by comparing the list of species we recorded with a list of species likely to be present based on previous research and/or expert opinion. For all species accumulation curves, we randomized the order of the sampling periods to break up clusters of new detections that resulted from temporal conditions (e.g., monsoon initiation) independent of cumulative effort. We used the computer program Species Richness and Diversity III (Pisces Conservation Ltd., IRC House, Pennington, Lymington, UK) to calculate species accumulation curves where the order of samples was shuffled $>10$ times and the average is plotted, thereby smoothing the curve.

Table 1.1. Museums that were queried in 1998 for vertebrate specimen vouchers with "Arizona" and "Fort Bowie National Historic Site" in the collection location. Collections in bold-faced type had specimens from Fort Bowie NHS. See Appendix E for results.

\begin{tabular}{ll}
\hline Collection & Collection cont. \\
\hline Chicago Academy of Sciences & Peabody Museum, Yale University \\
\hline Cincinnati Museum of Natural History \& Science & Saguaro National Park \\
\hline Cornell Vertebrate Collections, Cornell University & Strecker Museum, Baylor University, Waco \\
\hline George Mason University (Fairfax, VA) & Texas Cooperative Wildlife Collection \\
\hline Marjorie Barrick Museum, University of Nevada-Las Vegas & University of Arizona \\
\hline Michigan State University Museum (East Lansing) & University of Texas, Arlington \\
\hline Milwaukee Public Museum & University of Illinois, Champaign-Urbana \\
\hline Museum of Texas Tech University & University of Colorado Museum \\
\hline Museum of Vertebrate Zoology, University of California, Berkeley & Walnut Canyon National Monument, Arizona \\
\hline Museum of Life Sciences, Louisiana State University, Shreveport & Western Archaeological and Conservation Center, Tucson \\
\hline North Carolina State Museum of Natural Sciences & Wupatki National Monument, Arizona \\
\hline Oklahoma Museum of Natural History, Norman & \\
\hline
\end{tabular}




\section{Technical Concepts}

\section{Sampling Design}

Sampling design is the process of selecting sample units from a population or area of interest (for a review, see Thompson [1992]). Random samples allow inference to the larger population from which those samples were drawn, and estimate the true value of a parameter. Nonrandom samples are less likely to be representative of the entire population, because the sample may (intentionally or not) be biased toward a particular characteristic, perhaps of interest or convenience.

We briefly address sampling design in each chapter. Our surveys were not randomly located because we were more interested in detecting the maximum number of species than in providing inference to a larger area. Thus, abundance estimates (relative abundance, useful as an index to true abundance) detailed in this report may be biased because we surveyed in areas likely to have high species richness; however, the nature or extent of that bias is difficult to characterize or quantify. If population estimates were a higher priority, avoiding this potential bias would have greater importance.

\section{Estimates of Abundance}

Estimating population size is a common goal of biologists, generally motivated by the desire to reduce (e.g., pest species), increase (e.g., endangered species), maintain (e.g., game species) or monitor (e.g., indicator species) population size. Our surveys at Fort Bowie NHS were generally focused on detecting species rather than estimating population size. In many cases, however, we present estimates of "relative abundance" by species, which is an index to population size; we calculate it as the number of individuals of a species recorded, scaled by survey effort. Some researchers (particularly plant, marine, and invertebrate ecologists) prefer to scale such frequency counts by the number of observations of other species, which provides a measure of community dominance; abundance relative to other species present. If we completed multiple surveys in comparable areas (e.g., anywhere within Fort Bowie NHS), we included a measure of precision (usually standard error) with the mean of those survey results.

Indices of abundance are presumed to correlate with true population size but do not typically attempt to account for variation in detectability among different species or groups of species under different conditions. Metrics (rather than indices) of abundance do consider variation in detection probability, and these include density (number of individuals per unit area; e.g., two black-throated sparrow per hectare of semi-desert grassland), and absolute abundance (population size; e.g., 28 black-throated sparrow at Fort Bowie NHS). These latter techniques are beyond the scope of our research. While it is true that indices to abundance have often been criticized (and with good reason, c.f. Anderson 2001), the abundance information that we present in this report is used to characterize the commonness of different species rather than to quantify changes in abundance through space (e.g., habitat-use studies) or time (e.g., monitoring). As such, relative abundance estimates are more useful than (1) detectability-adjusted estimates of density for only a few species or (2) raw count data for all species without scaling counts by search effort. For a review of methods used to estimate abundance, see Lancia et al. (1996). 


\section{Chapter 2: Park Overview}

\section{Park Area and History}

Fort Bowie National Historic Site (NHS) is located in southeastern Arizona approximately $22 \mathrm{~km}$ south of the town of Bowie, Arizona (Fig. 2.1). The park lies in Apache Pass between the Chiricahua Mountains to the south and the Dos Cabezas Mountains to the north.

Fort Bowie NHS was established in 1964

to preserve the historic dwellings of Fort Bowie, a 19th century U.S. military outpost, prehistoric structures associated with Apache Spring, and a portion of the Butterfield Overland Trail and Station (NPS 2001). The park also commemorates the fort's soldiers, the Chiricahua Apaches, and the settlement of the west (NPS 2001). The park, which encompasses 405 ha, is administered by Chiricahua National Monument. Recent annual visitation is approximately 9,500 (NPS 2005).

\section{Natural Resources Overview}

\section{Physiography, Geology and Soils}

Fort Bowie NHS is located in Apache Pass, which separates the San Simon and the Sulphur Springs Valleys. Elevation at the park ranges from 1,400 m to $1,600 \mathrm{~m}$. The park contains three riparian areas: Siphon Canyon, Cutoff Canyon, and Willow Gulch. The geology of the park is characterized by the Apache Pass Fault made of Pennsylvanian and Cretaceous limestone on top of Precambrian granite (Denney and Peacock 2000). In some areas small fan terraces have formed from the granitic alluvium deposited by drainageways. For a complete soil survey, see Denny and Peacock (2000).

\section{Hydrology}

There are no perennial-flowing streams, but two springs, Apache and Mine Tunnel, are found within the park. Three other springs are outside, but near to the boundary of the park: Siphon, Bear, and Goodwin springs. Currently, half of the water flow of Apache Springs can be diverted to adjacent lands for use in cattle tanks, though this is rarely realized (Alan Whalon, pers. comm.). Siphon Canyon and Willow Gulch have ephemeral flow during summer (monsoonal) and winter rains (NPS 2001).

\section{Climate}

Fort Bowie NHS experiences an annual bimodal pattern of precipitation that is characterized by heavy summer (monsoon) storms from the Gulf of Mexico, and less intense frontal systems from the Pacific Ocean in the winter. On average, approximately one-half of the annual precipitation falls from July through September (Table 2.1; WRCC 2005). The area's hot season occurs from April through October; maximum temperatures in July can exceed $40^{\circ} \mathrm{C}$. Winter temperatures dip below freezing and snow is occasional. Based on data from Bowie, Arizona (the closest climate station), average annual precipitation totals during the course of our study were significantly lower than the long-term mean $(27.3 \mathrm{~cm})$ in $2002(21.5$ $\mathrm{cm})$ and $2003(19.3 \mathrm{~cm})$, but similar for $2004(29.3$ $\mathrm{cm}$ through October 2004) (Fig 2.3; WRCC 2005). Average annual temperatures during all years of our survey were above the long-term mean of $17.7^{\circ} \mathrm{C}\left(17.8^{\circ} \mathrm{C}\right.$ in $2002,18.3^{\circ} \mathrm{C}$ in 2003 , and $18.9^{\circ} \mathrm{C}$ through October 2004$)$.

Table 2.1. Average monthly climate data for Bowie, Arizona, 1899-2004. Data from WRCC (2005).

\begin{tabular}{lcccccccccccccc}
\hline & \multicolumn{10}{c}{ Month } & \\
\cline { 2 - 12 } Characteristic & Jan & Feb & Mar & Apr & May & Jun & Jul & Aug & Sep & Oct & Nov & Dec & Annual \\
\hline Maximum temperature $\left({ }^{\circ} \mathrm{C}\right)$ & 16.2 & 18.7 & 22.2 & 26.8 & 31.7 & 36.8 & 36.8 & 35.3 & 33.2 & 27.8 & 20.7 & 15.7 & 26.8 \\
\hline Minimum temperature $\left({ }^{\circ} \mathrm{C}\right)$ & -0.7 & 1.2 & 3.7 & 7.0 & 11.5 & 16.6 & 19.7 & 18.7 & 15.2 & 9.0 & 2.6 & -0.5 & 8.7 \\
\hline Precipitation $(\mathrm{cm})$ & 2.1 & 2.0 & 1.5 & 0.7 & 0.6 & 0.9 & 5.2 & 5.3 & 2.6 & 2.2 & 1.5 & 2.4 & 2.3 \\
\hline
\end{tabular}




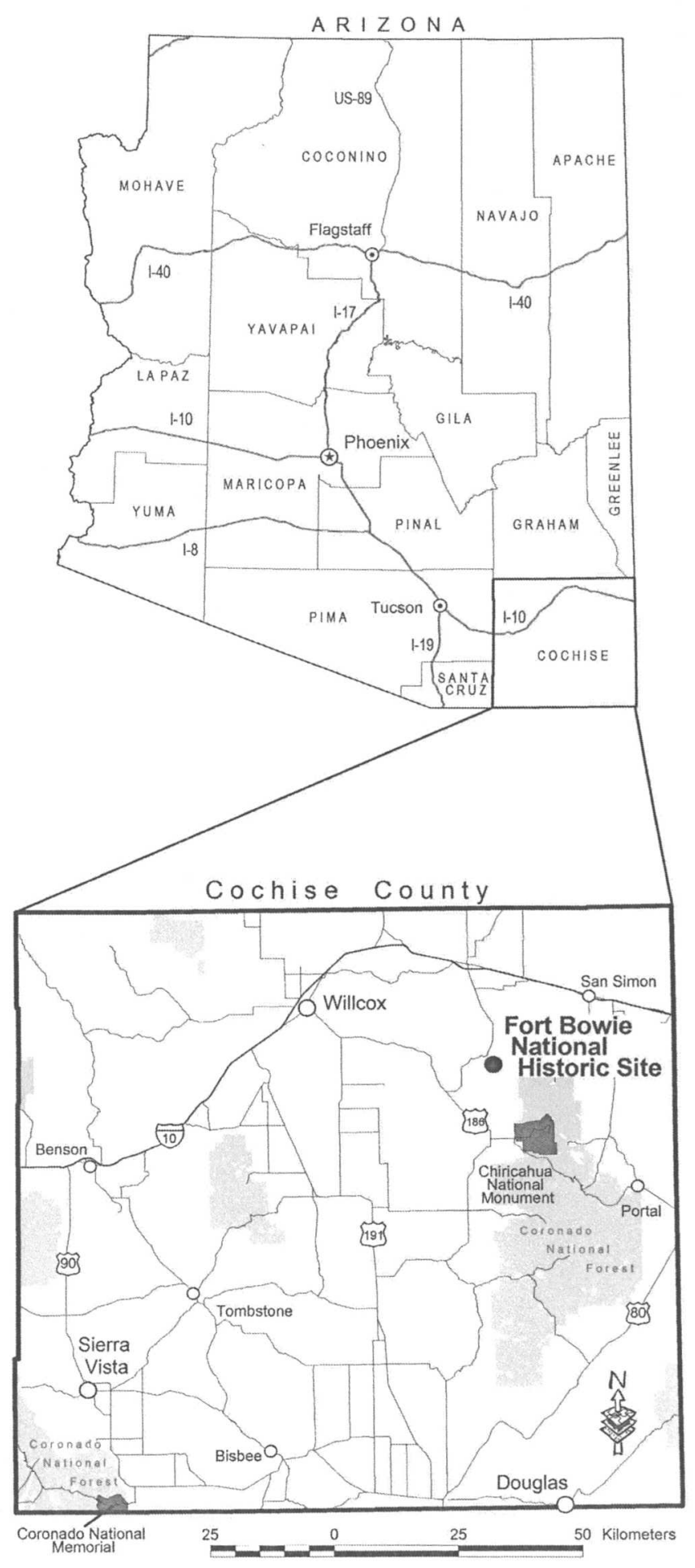

Figure 2.1. Location of Fort Bowie NHS in southern Arizona. 


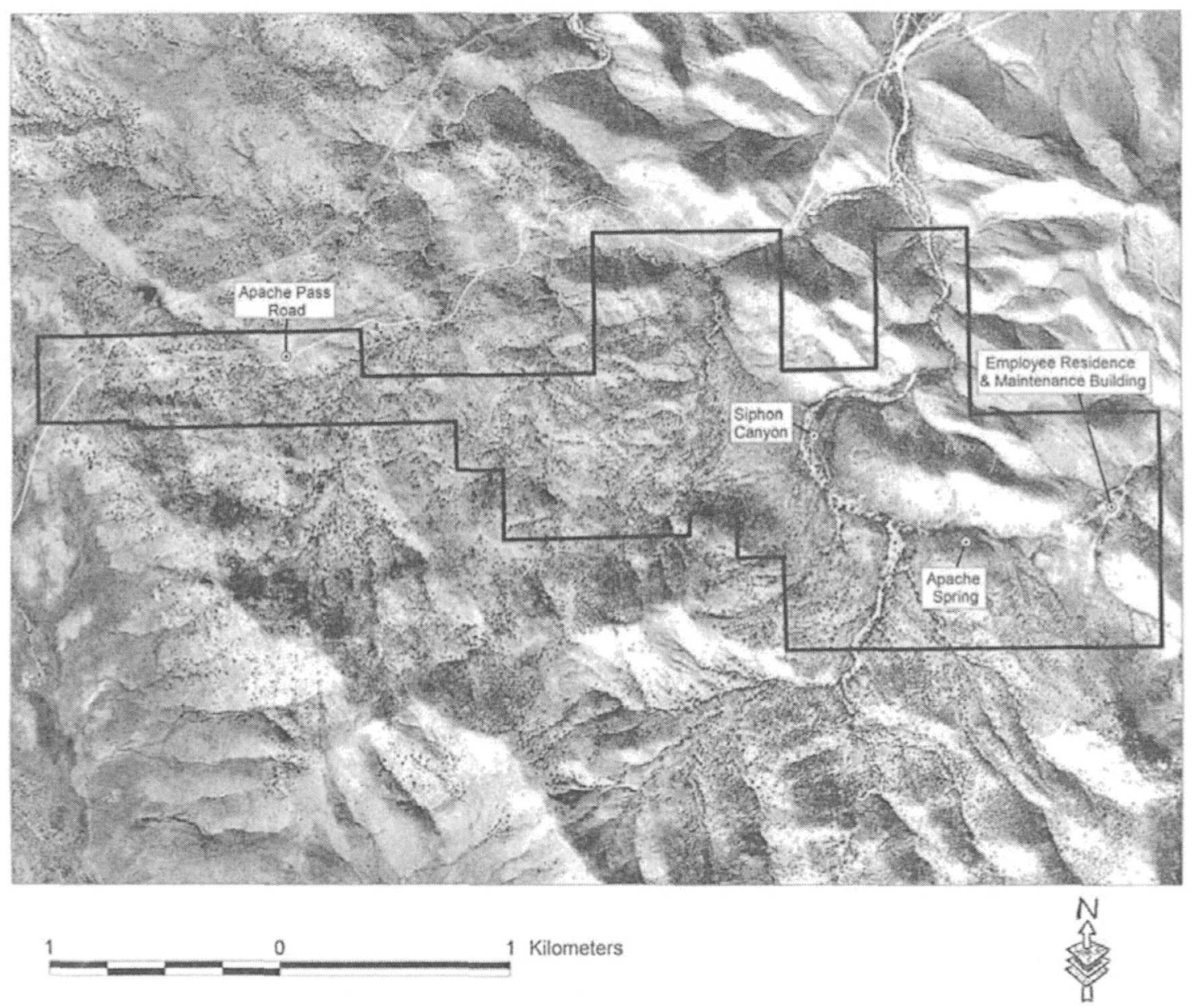

Figure 2.2. Aerial photograph of Fort Bowie NHS showing some of the major features.

\section{Vegetation}

Fort Bowie NHS contains four major vegetation communities (based on Warren et al. [1992]):

\section{- Madrean Evergreen Forest and}

Woodland containing Emory Oak-Pointleaf Manzanita- Beargrass Association, Emory Oak-Turpentine bush-Grama Grass Association, Scrub Oak-Bear GrassOneseed Juniper Association and Desert Deerbrush-Alder-leaf Mountainmohogany-Desert Sumac Association;

- Semi-desert Grassland containing Velvet Mesquite-Turpentine bush-Burroweed Association, Turpentine bush-Fairy Duster-Ocotillo Association, Ocotillo-Mariola-Grama Grass Association, Velvet Mesquite-Desert Sumac-Snakeweed Associations and Russian Thistle-Snakeweed-Mixed Grass Association;
- Chihuahuan Desertscrub containing Creosote-bush-Velvet Mesquite-Mariola Association; and

- Interior Southwestern Riparian Deciduous Forest and Woodland containing Arizona Walnut-Netleaf Hackberry-Gum Bumelia Association.

Historic photographs from the era of settlement show that juniper and oak trees were not abundant in the area near the fort, presumably because the trees had been cut for firewood (Warren et al. 1992). More recently, mesquite trees have invaded the semi-desert grassland areas of the park, most likely as a result of fire suppression and cattle grazing (NPS 2000b). Park personnel have removed many of the large mesquite trees that encroached into the area near the fort ruins. (NPS 2001). 

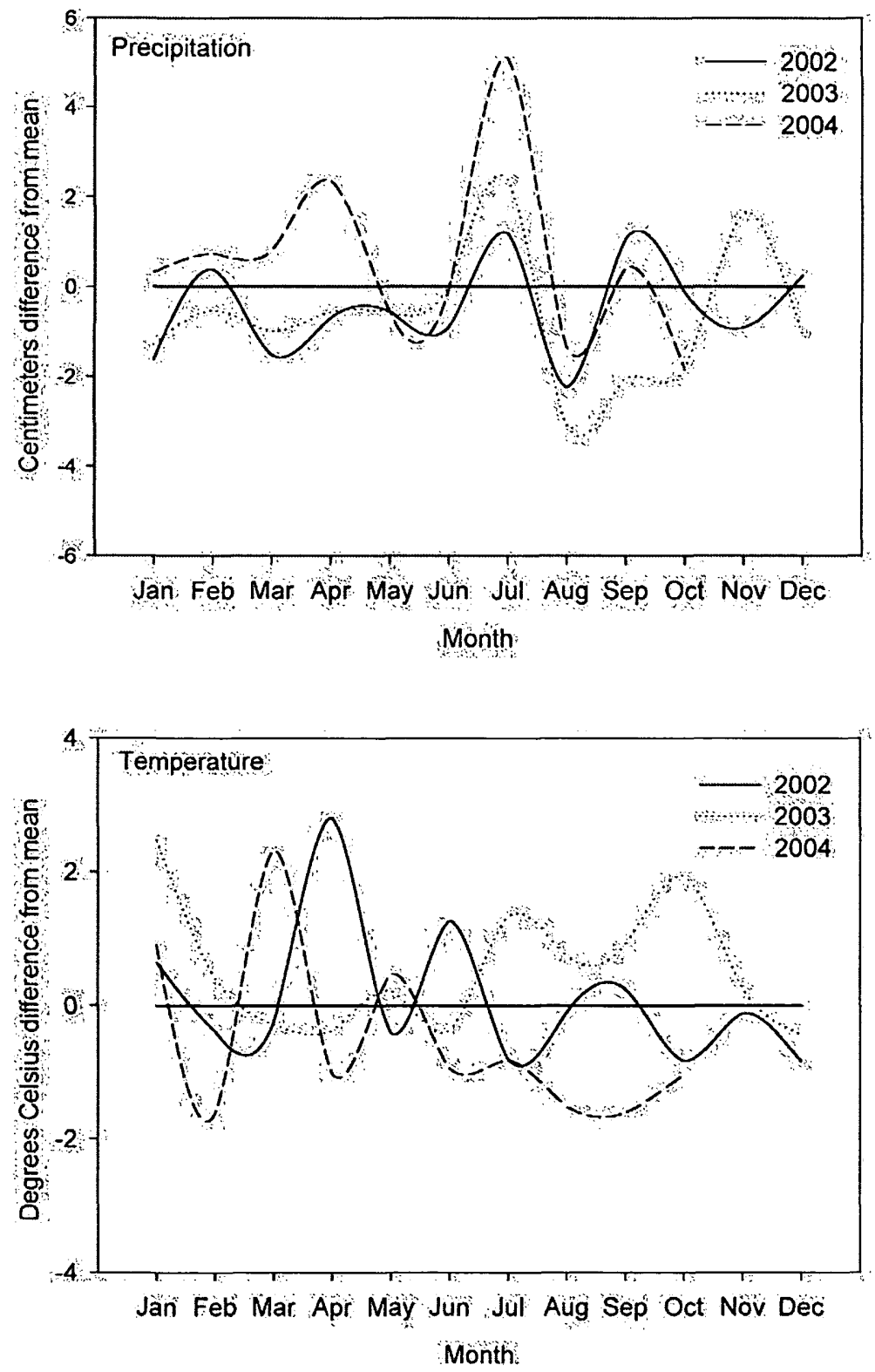

Figure 2.3. Comparison of monthly weather data during the time of the inventory (2002-2004) compared to the long-term mean (1899-2004; thick solid line in both figures), Bowie, Arizona. Data from WRCC (2005).

\section{Natural Resource Management Issues}

\section{Cattle Grazing}

Two cattle grazing allotments at the park were recently retired, though trespass of cattle onto the park is common. Livestock grazing has degraded an estimated $80 \%$ of streams and riparian ecosystems in the western United States through loss of vegetation, stream-bank erosion, soil compaction, flooding, and water pollution (Bahre
1991, BLM 1994, Fleischner 1994). Livestock grazing can also increase the number and extent of non-native plants (Belsky et al. 1999) and can negatively affect wildlife through habitat modification and competition for resources (Saab et al. 1995). At Fort Bowie, cattle have decreased grass cover, damaged historic artifacts, and helped to spread woody plants, such as mesquite, into what was once predominantly semi-desert grassland (NPS 2001). 


\section{Non-Native Species}

Lehmann lovegrass and other non-native grasses are the most important non-native species issue at the park. The change in species composition in the semi-desert grassland to a community dominated by Lehmann lovegrass, in particular, can alter the fire regime of the area by supporting higher fire frequencies, thereby leading to other changes in vegetation composition and structure including a loss of species richness (Anable et al. 1992).

The presence of American bullfrogs is another important non-native species management issue. Bullfrogs are native to eastern North America but have been introduced throughout the western U.S. for food production and sport (Stebbins 2003). American bullfrog adults and tadpoles are voracious predators (Kiesecker and Blaustein 1997) and are thought to be partially responsible for the decline of many native reptiles (Schwalbe and Rosen 1988) and amphibians (particularly other Ranid frogs; Hayes and Jennings 1986, Lawler et al. 1999) in the southwest.

\section{Undocumented Immigrants}

Approximately 20 undocumented immigrants pass through the park each week (NPS 2003). In addition to compromising visitor safety, border crossers also adversely impact the natural resources; they have created trails (including into the fort ruins), damaged vegetation, and have left trash behind. These impacts affect water quality and wildlife movement patterns, though the extent of these impacts has not been established.

\section{Adjacent Land Use}

Due to its small size, the park is easily affected by land management practices (e.g., development, mining, grazing, and hunting) outside its boundaries. Currently there is a Buddhist retreat center being built to the north of the park, but because the remainder of the land surrounding the park is managed by the BLM, ex-urban housing development is unlikely to significantly affect the park's resources. 


\section{Chapter 3: Plant Inventory}

\section{Previous Research}

Warren et al. (1992) completed the most thorough inventory of plants at Fort Bowie NHS (Appendix A). Most of the specimen vouchers reported by Warren et al. were collected by Marina Hoy from 1972 to 1977 . The collection is comprised of 471 species and subspecies. Warren et al. reported that most of the specimens were located at the park with "duplicates of selected species at the University of Arizona". However, in a recent search of the UA collections, Halvorson (2003) did not find any specimens from this study. Bennett et al. (1996) compiled a species list for the Chiricahua Mountains and vicinity (including Fort Bowie NHS) from a variety of sources including: complete examination of herbaria at Chiricahua National Monument, Fort Bowie NHS, the Southwestern Research Station, and minimal examination of herbaria at the University of Arizona, Arizona State University, and New Mexico State University. In their annotated species list, Bennett et al. indicated if the plant was found at Fort Bowie NHS. Most of the species attributed to Fort Bowie NHS were from the collections made by Marina Hoy, therefore there is considerable overlap between the Bennett et al. list and that by Warren et al. (1992; Appendix A). Ruyle (2001) assessed range conditions at eight permanently marked transects: six in the park and two outside (but near) the park. He found ten species of plants new to the park though he did not, to our knowledge, collect specimens. His work remains the only plot-based plant research at the park. Halvorson and Guertin (2003) mapped the distribution of 22 non-native plant species in the park from the fall of 1999 to the spring of 2001. There are two other poorly documented plant species lists for the park. NPS (2000a) produced an annotated species list for Fort Bowie NHS. This list appears to be compiled from Warren et al. (1992) and Bennett et al. (1996) but these sources do not entirely make up the list (Appendix A). Finally, Hartman and Rottman (1998) compiled a checklist for the park but again, no documentation exists from their work.

\section{Methods}

To complete the species list for the park, we used "general botanizing" surveys, during which observers walked throughout the park (particularly around the parade grounds and along trails) and opportunistically collected and recorded plants. In addition to our own results, we present here the first synthesis of findings from past studies and collections.

\section{Spatial Sampling Design}

Our survey crews walked throughout the park on each visit. They did not record their search paths, but indicated the location of each collection.

\section{General Botanizing}

\section{Field Methods}

Whenever possible we collected at least one representative specimen (with reproductive structures) for each plant species that were thought to represent a new species for the park. When we collected a specimen we recorded flower color, associated dominant vegetation, date, collector name(s), and UTM coordinates. We pressed the specimens immediately upon collection. Specimens remained pressed for 2-3 weeks and were frozen for 48 hours to prevent infestation by insects and pathogens. We then mounted the specimens and accessioned them into the University of Arizona Herbarium.

\section{Effort}

We made nine day-long visits, typically with two observers, on 28 September and 5, 6, 9, 23, 29, and 31 October 2002 and on 6 and 9 May 2003.

\section{Results and Discussion}

We found 193 species and subspecies, including 33 new species for the park (Appendix A). Of these, we found two species representing new families for the park and nine species representing new genera for the park. Of particular note were three species of Euphorbia, a new genus for the park. Of the 33 species new for the park, only one was non-native. 
Considering all available sources, there have been 638 species and subspecies recorded at the park, of which $38(6 \%)$ are non-native (Appendix A). The percentage of non-native plants in the park's flora is low compared to other sites in southeastern Arizona (e.g., Burgess et al. 1991, Powell et al. 2005a). The number and extent of non-native plants may be buffered by the lack of roads through the park. Roads act as dispersal corridors for non-native plant species, which often thrive in the adjacent disturbed soils. Although the park has a low percentage of non-native species, the percent of area covered by them is greater. Halvorson and Guertin (2003) mapped the distribution of 22 species of non-native plants at the park. Lehmann lovegrass was the most widespread of the non-native species and other non-native species were especially prevalent around the visitor center. Ruyle (2001) established plots and his work remains the only study that is able to quantify the dominance and relative abundance of plants. Yet because of the diversity of vegetation communities and conditions in the park, Ruyle did not survey enough plots to address the dominance of non-native species; he found no nonnative species during his surveys, but clearly did not have plots in the semi-desert grasslands west of Siphon Canyon (near the cemetery) where Lehmann lovegrass dominates. In Chapter 6 we make recommendations for more plot-based survey work.

The number of species documented for the park far outnumbers the expected species richness (330), based on size and topographic relief of the park (Warren et al. 1992). The extraordinary species richness that has been found at the park is due to three main factors: geographic location of park, geologic faults separating different rock substrates, and the presence of permanent water.

Fort Bowie NHS lies at the juncture to four major biogeographical provinces: Madrean, Rocky Mountain, and Sonoran and Chihuahuan deserts. The Madrean biogeographic region in particular is well represented in the flora of the park, and this region has the highest plant species richness in
Arizona (Bowers and McLaughlin 1982). Other floristic influences are from the Great Plains and Chihuahuan regions (Warren et al. 1992).

The high species richness at the park is also the result of local influences from two faults that pass through the park: Apache Pass and Fort Bowie faults (Denny and Peacock 2000). These faults separate major geologic substrates including limestone, shale, sandstone, and granitic and metamorphic rock, all of which give rise to conditions that favor certain plant species. For example, Warren et al. (1992) noted that a number of species with primarily Chihuahuan desert distributions are found on limestone outcrops at Fort Bowie NHS.

Finally, the perennial Apache Spring gives rise to the third determinant of high species richness and vegetation communities at the park. The presence of water is responsible for the vegetation structure in the riparian area, which is in stark contrast to upland areas, and also is an important determinant of vertebrate species richness and abundance (see Chapters 4 and 5).

\section{Inventory Completeness}

Fort Bowie NHS has one of the most complete inventories for vascular plants in all of the Sonoran Desert Network parks. Based on our work and that by others, we believe that the inventory is likely $90 \%$ complete. We found 33 new species, a $5 \%$ increase in the number of plants for the park. Additional surveys, particularly during the late spring, will add more species to the park list, but considering our survey effort, we believe the percentage of new species found will not be significant (see Chapter 7 for additional information on more studies). However, of particular concern in all natural areas is the increase in the abundance and distribution of nonnative species. This will likely happen if Cochise County paves Apache Pass Road, thereby increasing the number of vehicles in the area (see Chapter 6). 


\section{Chapter 4: Bird Inventory}

\section{Previous Bird Research}

The first comprehensive inventory of birds at the park was in 1975 and 1976 by Russell and Johnson (1976) who surveyed five transect routes multiple times in all seasons. They reported abundance of species based on the number of observations per hour of surveys. Although no original data exist from that study (Terry Johnson, pers. comm.), the transect routes were similar to those used by our survey crews and we therefore make gross comparisons between our two studies. Many of the observations of rare birds noted in that report are from Marina Hoy. Fischer (2002) compiled a list of bird species at the park based on: (1) field observations made in the early 1990s (Dan Fischer, pers. comm.) and (2) review of bird lists and specimens from the region. Typically we do not consider species lists credible forms of evidence of species occurrence in an area; often these lists are not well documented. However, the list by Fischer (2002) is well documented and is mostly based on his field experience. We therefore use it to create the species list for the park (Appendix C). In 2002 and 2003 there was a Monitoring Avian Productivity and Survivorship (MAPS; DeSante and O'Grady 2000) banding station at the park, which was operated by staff from the Southeastern Arizona Bird Observatory. Finally, we found specimen vouchers, representing 20 species, which were collected in 1893 and 1894 (Appendix E).

\section{Methods}

We surveyed for birds at Fort Bowie NHS in 2003 and 2004. We used four field methods: variable circular-plot (VCP) counts for diurnal birds during the breeding season, nocturnal surveys for owls and nightjars, line transects for birds in the nonbreeding season, and incidental observations for all birds in all seasons. Although winter bird surveys were not included in the original study proposal (Davis and Halvorson 2000), we felt they were important in our effort to inventory birds at the park because many species that use the area during the fall and winter may not be present during spring and summer (breeding season) surveys. We concentrated most of our survey effort during the breeding season because bird distribution is relatively uniform at this time (due to territoriality among most landbird species) (Bibby et al. 2000). Therefore, surveying during the breeding season increased our precision in estimating relative abundance and also enabled us to document breeding activity. Our survey period included peak spring migration times for most species, adding many migratory species to our list. We also sampled vegetation in the vicinity of VCP stations. Vegetation structure and plant species composition are important predictors of bird species richness or the presence of particular species (MacArthur and MacArthur 1961, Rice et al. 1984, Strong and Bock 1990, Powell and Steidl 2000).

In most cases we do not report observations that failed to determine species (e.g., "unknown woodpeckers"). Ravens are an exception. Both Chihuahuan and common ravens occur at the park and both species are difficult to differentiate unless they are viewed at a short range under certain conditions or if they are seen flying together (Bednarz and Raitt 2002). We were not able to positively determine the species for any raven sighting and therefore report all observations as "unknown raven."

\section{Spatial Sampling Design and General Vegetation Characteristics}

We subjectively placed the two VCP transects in areas that we believed would have the highest species richness (Siphon Canyon) and would be representative of the dominant vegetation at the park (Butterfield). Some sections of our survey locations correspond to those of Russell and Johnson (1976). The Siphon Canyon transect ran from Apache Spring to where the canyon exits the park (Fig. 4.1). The Butterfield transect began near the junction of the namesake trail and Siphon Canyon and ended near the western boundary of the park (Fig. 4.1; see also Fig. 4.2).

The Butterfield transect follows its namesake trail and it is more xeric than the Siphon Canyon transect. It is dominated by Emory oak and oneseed juniper (Table 4.1) with a wide variety of shrub such as turpentine bush, sotol, manzanita, agave, and yucca (Fig. 4.1). The Siphon Canyon 

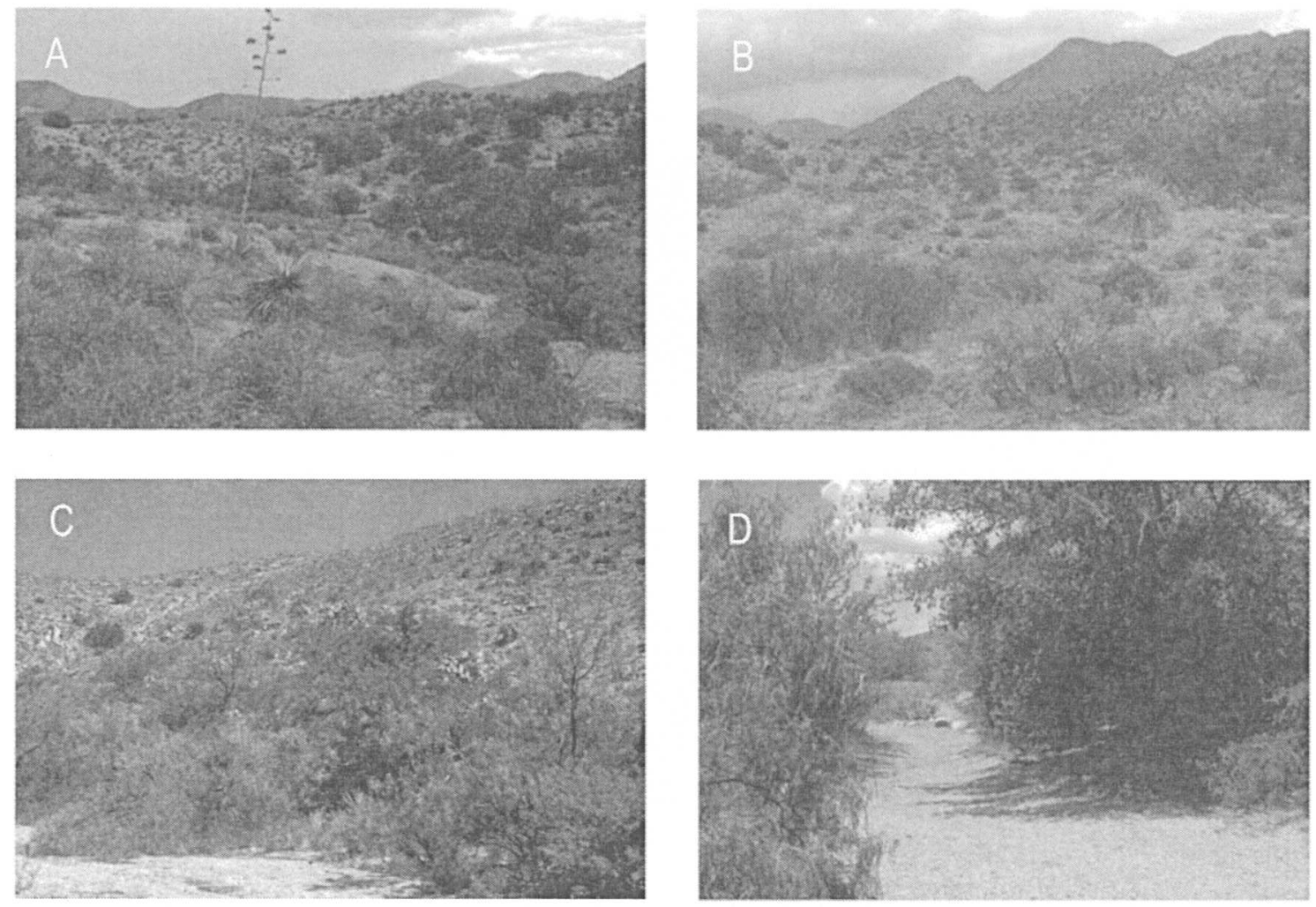

Figure 4.1. Photographs taken from bird survey stations, Fort Bowie NHS. Photographs A and B are looking east from Butterfield transect station numbers 8 and 6 , respectively. Photographs $C$ and $D$ are looking north from Siphon Canyon station numbers 6 and 5, respectively. See Fig. 4.2 for location of stations.

transect has some areas of very dense vegetation, including netleaf hackberry, Arizona oak, and Utah juniper near Apache Spring (Table 4.1). Other riparian vegetation, including desert willow and Arizona walnut, is in the bottom of Siphon Canyon (Fig. 4.1). The upslope areas are similar to the Butterfield transect, but with few Emory oak (Table 4.1).

\section{VCP Surveys}

\section{Field Methods}

We used the variable circular-plot method to survey for diurnally active birds during the breeding season (Reynolds et al. 1980, Buckland et al. 2001). Conceptually, these surveys are similar to traditional "point counts" (Ralph et. al 1995), during which an observer spends a standardized length of time at one location (i.e., station) and records all birds seen or heard and the distance to each bird or group of birds.

We surveyed the Siphon Canyon transect in 2003 and 2004 and the Butterfield transect in
2004 (Table 4.2). Each transect consisted of eight stations, each located a minimum of $250 \mathrm{~m}$ apart to maintain independence among observations at each station. We surveyed each year from mid April through early July, the period of peak breeding activity for most species in the area.

On each visit to a transect we alternated the order in which we surveyed stations to minimize bias by time of day and direction of travel. We did not survey when wind speed exceeded $15 \mathrm{~km} / \mathrm{h}$ or when precipitation exceeded an intermittent drizzle. We began bird surveys approximately 30 minutes before sunrise and concluded no later than three hours after sunrise.

We recorded a number of environmental variables at the beginning of each transect: wind speed (Beaufort scale), presence and severity of rain (qualitative assessment), air temperature $\left({ }^{\circ} \mathrm{F}\right)$, relative humidity (\%), and cloud cover (\%). After arriving at a station, we waited one minute before beginning the count to allow birds to resume their normal activities. We identified to species all birds 
seen or heard during an eight-minute "active" period. For each detection we recorded distance in meters from the observer (measured with laser range finder when possible), time of detection (measured in one-minute intervals beginning at the start of the active period), and the sex and/or age class (adult or juvenile), if known. We did not measure distances to birds that were flying overhead, nor did we use techniques to attract birds (e.g., "pishing"). We made an effort to avoid double-counting individuals that had been recorded at previous stations. During the "passive" count period (between the eight-minute counts), if we observed a species that had not been recorded previously at a station on that visit, we recorded its distance to the nearest station.

\section{Effort}

We surveyed the eight stations of the Siphon Canyon transect five times in 2003 and the Siphon Canyon and Butterfield transects (also eight stations) six times each in 2004 (Table 4.2). We visited each station for eight minutes on each visit.

Table 4.1. Mean density (ha) of the most common tree species at each station along the two VCP transects, Fort Bowie NHS, 2004. Data summarized from Appendix F. Numbers represent the number of individuals observed in the "tree" and "potential cavity-nesting" categories from point-quarter sampling. Species present on $>4$ stations are included in this summary. See Appendix A for scientific names.

\begin{tabular}{|c|c|c|c|c|c|c|c|c|c|c|c|}
\hline \multirow[b]{2}{*}{ Transect } & \multirow[b]{2}{*}{ Station } & \multicolumn{10}{|c|}{ Species } \\
\hline & & $\begin{array}{c}\text { netleaf } \\
\text { hackberry }\end{array}$ & $\begin{array}{l}\text { desert } \\
\text { willow }\end{array}$ & $\begin{array}{l}\text { Arizona } \\
\text { walnut }\end{array}$ & $\begin{array}{l}\text { oneseed } \\
\text { juniper }\end{array}$ & $\begin{array}{l}\text { Utah } \\
\text { juniper }\end{array}$ & $\begin{array}{c}\text { velvet } \\
\text { mesquite }\end{array}$ & $\begin{array}{c}\text { Arizona } \\
\text { oak }\end{array}$ & $\begin{array}{l}\text { Emory } \\
\text { oak }\end{array}$ & $\begin{array}{l}\text { desert } \\
\text { sumac }\end{array}$ & $\begin{array}{l}\text { gum } \\
\text { belly }\end{array}$ \\
\hline Butterfield & 1 & 0.7 & & 2.4 & 0.7 & 0.7 & 8.7 & & & 2.7 & \\
\hline & 2 & 6.9 & & & & 6.9 & 20.8 & & 14.4 & & \\
\hline & 3 & & & & & 1.9 & 1.8 & 1.9 & 25.9 & & \\
\hline & 4 & & & & 4.1 & & 10.1 & 1.7 & 23.1 & & \\
\hline & 5 & & & & 2.8 & & & 3.4 & 7.4 & & \\
\hline & 6 & & & & 11.3 & & 3.8 & & 14.0 & & \\
\hline & 7 & & & & 3.5 & & 2.6 & 1.8 & 11.5 & & \\
\hline & 8 & & & & 6.0 & & 1.5 & 1.6 & 3.7 & & \\
\hline Siphon Canyo & on 1 & 5.1 & & 2.2 & 5.1 & 6.2 & 8.1 & 6.3 & & & 12.2 \\
\hline & 2 & 8.6 & & 0.8 & 6.5 & & 15.5 & 2.3 & & 4.2 & 21.0 \\
\hline & 3 & 7.0 & 11.0 & 4.4 & & & 11.4 & & 1.3 & 16.7 & \\
\hline & 4 & 46.8 & 11.2 & 5.4 & & & 19.3 & & & 20.9 & 15.8 \\
\hline & 5 & 6.9 & 3.1 & 6.2 & 1.5 & & 6.9 & & & & 9.2 \\
\hline & 6 & 8.2 & 17.0 & 3.0 & 2.5 & & 14.0 & & & 9.3 & 0.3 \\
\hline & 7 & 14.4 & & 3.0 & 3.1 & 3.4 & 3.1 & & & 15.7 & 3.1 \\
\hline & 8 & 4.2 & & 1.8 & & & 6.3 & 5.8 & & & 15.8 \\
\hline
\end{tabular}

Table 4.2. Summary of bird survey effort, Fort Bowie NHS, 2002-2004. Sample size ( $n$; number of visits multiplied by number of stations) was used to calculate relative abundance for each transect and year.

\begin{tabular}{lllccr}
\hline Survey type & Transect name & Year(s) & Visits & Stations/ sections & $n$ \\
\hline VCP & Butterfield & 2004 & 6 & 8 & 48 \\
\hline & Siphon Canyon & 2003 & 5 & 8 & 40 \\
\hline & & 2004 & 6 & 8 & 48 \\
\hline Line transect & Coach & $2002-2003$ & 4 & 6 & 24 \\
\hline & Siphon Canyon & $2002-2003$ & 4 & $5-6$ & 23 \\
\hline Nocturnal survey & Owl & 2003 & 3 & 5 & 15 \\
\hline & & 2004 & 3 & 5 & 15 \\
\hline
\end{tabular}



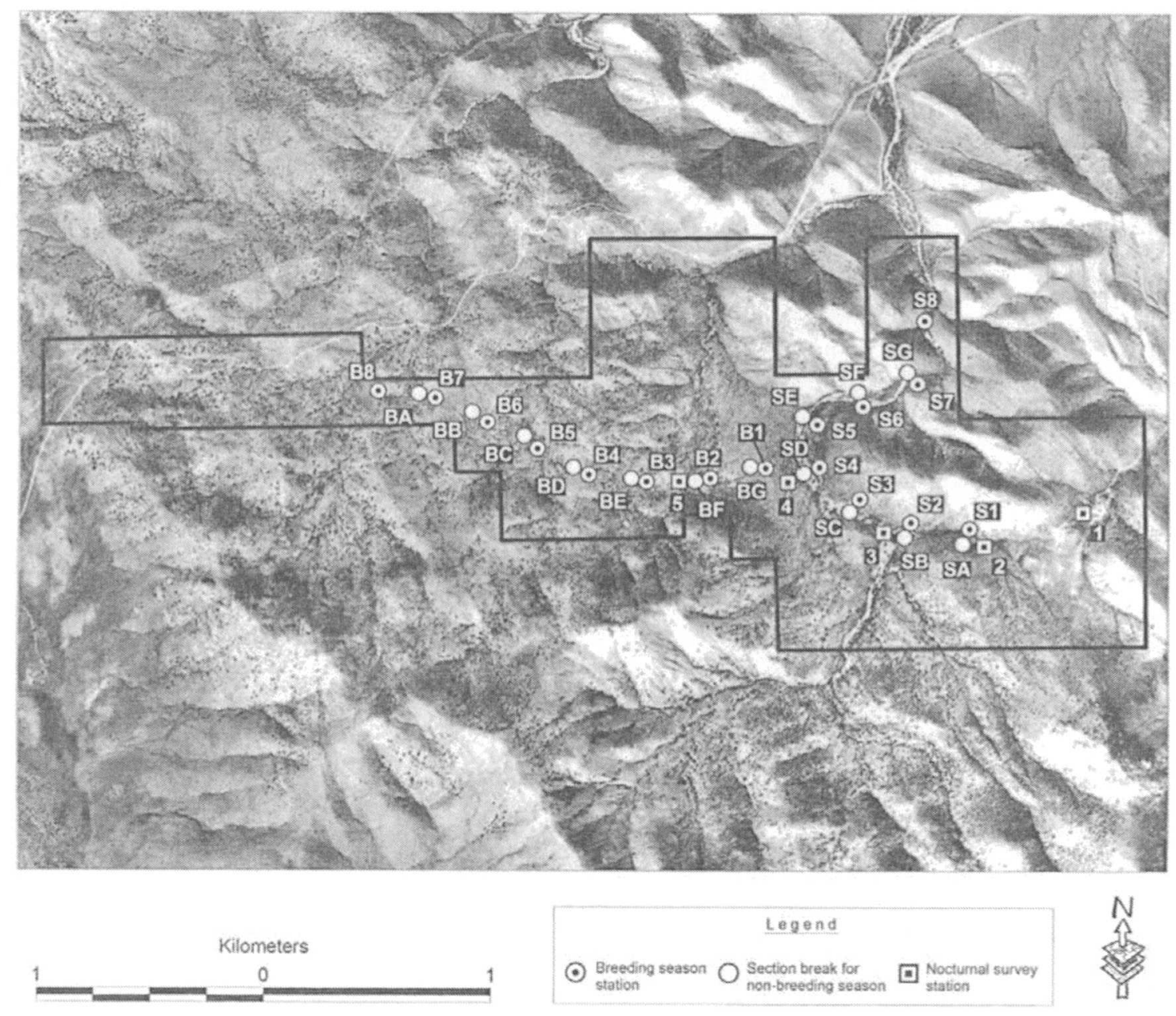

Figure 4.2. Location of bird surveys, Fort Bowie NHS, 2002-2004.

\section{Analyses}

We calculated relative abundance of each species along each transect as the number of detections at all stations and visits (including zero values) divided by effort (sample size: total number of visits multiplied by total number of stations). We reduced our full collection of observations for each VCP station ( $n=1,986: 1,378$ and 608 for Siphon Canyon and Butterfield transects, respectively) to a subset of data ( $n=1,093 ; 793$ and 244 for Siphon Canyon and Butterfield transects, respectively) that was more appropriate for estimating relative abundance. We used only those detections that occurred $\leq 75 \mathrm{~m}$ from count stations (thereby excluding 344 and 273 observations, respectively) because detectability is influenced by conspicuousness of birds (i.e., loud, large, or colorful species are more detectable than others) and environmental conditions (dense vegetation can reduce likelihood of some detections).

Truncating detections may reduce the influence of these factors (Verner and Ritter 1983; for a review of factors influencing detectability see Anderson 2001, Farnsworth et al. 2002). We also excluded observations of birds that were flying over the station (145 and 71 observations, respectively), birds observed outside of the eight-minute count period (128 and 45 observations, respectively), and unknown species (38 and 7 observations, respectively). Some observations met more than one of these criteria for exclusion from analysis. 


\section{Line-transect Surveys}

\section{Field Methods}

From 15 October 2002 to 9 January 2003 we surveyed for birds using the line-transect method (Bibby et al. 2002). Line transects differ from VCP transects, in that an observer records birds seen or heard while the observer walks a line, rather than remaining stationary. The transect method is more effective during the non-breeding season because bird vocalizations are less conspicuous and frequent, making birds more difficult to detect (Bibby et al. 2000). This method was once the preferred survey technique for surveys in all seasons and was used by Russell and Johnson (1976) in their surveys of the park.

We established two transects at the park

(Fig. 4.2). The transects were broken into sections, with the start and finish locations corresponding to the breeding-season stations. Each section was approximately $250 \mathrm{~m}$ in length. As with other survey methods, we alternated direction of travel along transects to reduce biases and did not survey during periods of excessive rain or wind (see breeding-season survey methods for details). We began surveys at sunrise and continued until we completed both transects. As with breeding-season surveys, we recorded weather conditions at the beginning and end of each survey. Prior to beginning a section, we recorded the section name (e.g., "A-B") and the start time.

We timed our travel so that we traversed each section in ten minutes, during which time we assigned all birds seen and/or heard into one of the following distance categories: $\leq 100 \mathrm{~m},>100 \mathrm{~m}$, or "flyover." When possible, we noted the sex and age class of birds. We recorded birds observed before or after surveys as "incidentals" (see section below), and we did not use techniques to attract birds (e.g., "pishing").

\section{Effort}

We surveyed all six sections of the Siphon Canyon and Butterfield transects four times each in the fall and winter of 2002 and 2003 (Table 4.2).

\section{Analysis}

We used all observations $(N=483)$, except unknown species, to estimate relative abundance (see Methods section of VCP surveys for more details).

\section{Nocturnal Surveys}

\section{Field Methods}

To survey for owls we broadcast commercially available vocalizations using a compact disc player and broadcaster (Colver et al. 1999, Bibby et al. 2002) and recorded other nocturnal species (nighthawks and poorwills) when detected. We established one transect from approximately the visitor center to $600 \mathrm{~m}$ west of Siphon Canyon, along the Butterfield Trail (Fig. 4.2). The transect had five stations that were a minimum of $300 \mathrm{~m}$ apart. As with other survey methods, we varied direction of travel along transects and did not survey during periods of excessive rain or wind. We began surveys approximately 45 minutes after sunset.

We began surveys at each station with a three-minute "passive" listening period during which time we broadcast no calls. We then broadcast vocalizations for a series of two-minute "active" periods. We used vocalizations of species that we suspected, based on habitat and range, might be present: elf, western screech, whiskeredscreech, barn, and (on one occasion) northern pygmy owl. We excluded great horned owl from the broadcast sequence because of its aggressive behavior toward other owls. We broadcast recordings of owls in sequence from smallest to largest size species so that smaller species would not be inhibited by the "presence" of larger predators or competitors (Fuller and Mosher 1987). During active periods, we broadcast owl vocalizations for 30 seconds followed by a 30 second listening period. This pattern was repeated two times for each species. During the count period we used a flashlight to scan nearby vegetation and structures for visual detections. If we observed a bird during the three-minute passive period, we recorded the minute of the passive period in which the bird was first observed, the type of detection (aural, visual or both), and the distance to the bird. If a bird was observed during any of the twominute active periods, we recorded in which interval(s) it was detected and the type of detection (aural, visual, or both). As with other survey types, we attempted to avoid double-counting individuals recorded at previous stations. We also used multiple observers, alternated direction of travel along transects, and did not survey during inclement weather. 
Effort

We surveyed all five stations on each of the three visits during the breeding season in both 2003 and 2004 (Table 4.2).

\section{Analysis}

Because of the low number of detections, we report only the number of detections and do not calculate relative abundance as for the other survey methods.

\section{Incidental and Breeding Observations}

\section{Field Methods}

When we were not conducting formal surveys and encountered a rare species, a species in an unusual location, or an individual engaged in breeding behavior, we recorded UTM coordinates, time of detection, and (if known) the sex and age class of the bird. We recorded all breeding behavior observations using the standardized classification system (developed by the North American Ornithological Atlas Committee; NAOAC 1990). This system classifies breeding behavior into one of nine categories: adult carrying nesting material, nest building, adult performing distraction display, used nest, fledged young, occupied nest, adult carrying food, adult feeding young, or adult carrying a fecal sac. We made breeding observations during both standardized surveys and incidental observations.

\section{Analysis}

We report frequency counts of incidental and breeding observations; we cannot calculate relative abundance because we did not standardize survey effort.

\section{Vegetation Sampling at VCP Stations}

In 2004 we sampled vegetation associated with each of the breeding-season stations along the Siphon Canyon and Butterfield transects. We sampled vegetation at five subplots located at a modified random direction and distance from each station. Each plot was located within a $72^{\circ}$ range of the compass from the station (e.g., Plot 3 was located between $145^{\circ}$ and $216^{\circ}$ ) to reduce clustering of plots. We randomly placed plots within $75 \mathrm{~m}$ of the stations to correspond with truncation of data used in estimating relative abundance.

At each plot we used the point-quarter method (Krebs 1998) to sample vegetation by dividing the plot into four quadrants along cardinal directions. We applied this method to plants in three height categories: sub-shrubs $(0.5-1.0 \mathrm{~m})$, shrubs $(>1.0-2.0 \mathrm{~m})$, trees $(>2.0 \mathrm{~m})$, and one size category: potential cavity-bearing vegetation ( $>20$ $\mathrm{cm}$ diameter at breast height). If there was no vegetation in a given category within $25 \mathrm{~m}$ of the plot center, we indicated this in the species column. For each individual plant, we recorded its distance from the plot center, species, height, and maximum canopy diameter (including errant branches). Association of a plant to a quadrant was determined by the location of its trunk, regardless of which quadrant the majority of the plant was in; no plant was recorded in more than one quadrant. Standing dead vegetation was only recorded in the "potential cavity-bearing tree" category. On rare occasions when plots overlapped we repeated the selection process for the second plot.

Within a 5-m radius around the center of each plot, we visually estimated (1) percent ground cover by type (bare ground, litter, or rock); and (2) percent aerial cover of vegetation in each quadrant using three height categories: $0-0.5 \mathrm{~m},>0.5-2.0$ $\mathrm{m}$, and $>2.0 \mathrm{~m}$. For both estimates we used one of six categories for percent cover: $0(0 \%), 10$ (1-20\%), 30 (21-40\%), 50 (41-60\%), 70 (61-80\%), and $90(81-100 \%)$.

\section{Analysis}

Using point-quarter data, we calculated mean density (number of stems/ha) for all species in each of the four height/size categories using the computer program "Krebs" (Krebs 1998). We collected these data to quantify vegetation characteristics around survey stations (Appendix F).

\section{Comparisons to Surveys by Russell and Johnson (1976)}

We summarized data from Russell and Johnson (1976) and made limited comparisons between their results and ours. To facilitate these comparisons, we used only those data from our surveys that corresponded to the study sites used by Russell and Johnson: their "wash-riparian" corresponds to our VCP stations numbers 1-4 and line transects sections A-B to D-E of our Siphon Canyon transect; their "mesquite-grassland" corresponds to our VCP stations numbers $1-4$ and line-transect sections A-B to D-E of our Butterfield 
transect; and their "oak-juniper woodland" corresponds to our VCP stations numbers 5-8 and line-transect sections E-F to I-J of our Butterfield transect. We combined relative abundance scores from Russell and Johnson for the spring and summer surveys and compared these data to our VCP surveys. We excluded fall surveys from comparison (they visited the park only twice in the fall of 1975) and made direct comparisons between their "winter" surveys and our line-transect surveys. Because of the different field methods (and therefore inappropriateness of comparing relative abundance estimates), we compared ranks of only the most abundant species.

\section{Results}

We found 109 species during surveys from October 2002 to July 2004 (Appendix C). We found 77 species during VCP surveys, 51 species during line transect surveys, four species during nocturnal surveys, and 72 species by incidental observation during all seasons. We found no non-native species. We found a number of species of high conservation concern including peregrine falcon, loggerhead shrike, and Baird's sparrow. Based on a review of other studies at the park, there have been 189 species observed at the park (Appendix C).

\section{VCP Surveys}

We found three species on the Butterfield transect that we did not find on the Siphon Canyon transect, and 36 species on the Siphon Canyon transect that we did not find on the Butterfield transect (Tables $4.3,4.4)$. Among the 36 species found only on the Siphon Canyon transect, some were among the most abundant on the transect: the Cassin's and western kingbirds, Bell's vireo, summer tanager, Bullock's and hooded orioles, and northern cardinal (Table 4.3). Most of these species are riparian obligate species. Among species that we found on both transects, and for which we were able to calculate relative abundance, there were some notable differences among transects: 10 species had higher mean relative abundance on the Butterfield transect, while 12 species had higher mean relative abundance on the Siphon Canyon transect (using the mean relative abundance scores from 2003 and 2004). There were no surprises in these numbers. Abundant species on the Butterfield transect are known to be associated with drier conditions: the black-throated sparrow, rufouscrowned sparrow, Bewick's wren, Scott's oriole, and canyon towhee. Similarly, the Siphon Canyon transect had species that reach their highest abundance in areas of dense vegetation: the whitewinged dove, Gambel's quail, verdin, and Lucy's warbler. In the Siphon Canyon transect in both 2003 and 2004 the northern cardinal, Gambel's quail, and white-winged dove were the most abundant (Table 4.3). On the Butterfield transect the mourning dove, black-throated sparrow, and Bewick's wren were the most abundant (Table 4.4).

We observed 69 species along the Siphon Canyon transect in 2003 and 2004, of which we were able to calculate relative abundance for 47 species (Table 4.3). We found 12 species in each year that we did not find the other year. With the exception of the crissal thrasher, the species not found in the other year were not among the most abundant (Table 4.3). Almost all relative abundance estimates were higher in 2004 (mean $\pm \mathrm{SE}=0.24 \pm$ $0.040)$ than in $2003(0.18 \pm 0.030 ; t=6.3, \mathrm{P}<$ .0001 on log transformed data). Among the most common species, only ash-throated flycatcher and verdin had much greater relative abundance estimates in 2003 than in 2004. Conversely, many abundant species such as mourning dove, Cassin's kingbird, Bewick's wren, and northern mockingbird had much higher relative abundance estimates in 2004 than in 2003.

\section{Line-transect Surveys}

We observed 50 species during line-transect surveys in 2002 and 2003, 35 species on the Butterfield transect and 41 species on the Siphon Canyon transect (Table 4.5). Nine species were unique to the Butterfield transect, while 16 species were unique to the Siphon Canyon transect. Excluding sandhill crane (observed only on one occasion flying over the park), Gambel's quail, chipping sparrow, and white-crowned sparrow were most abundant on the Butterfield transect (Table 4.5). On the Siphon Canyon transect, whitecrowned sparrow, Gambel's quail, American robin, and spotted towhee were the most abundant. 
Table 4.3. Total number of observations (Total obs.) and relative abundance (mean \pm SE) of birds observed during VCP surveys, Siphon Canyon transect, Fort Bowie NHS, 2003 and 2004. Total number of observations includes all birds observed during surveys whereas relative abundance estimates exclude birds observed $>75 \mathrm{~m}$ from stations, flyovers, and observations made outside of the eight-minute count period. Sum is the number of observations used in calculating relative abundance estimates. See Methods section for additional details on estimation of relative abundance and effort used in those calculations.

\begin{tabular}{|c|c|c|c|c|c|c|c|}
\hline \multirow[b]{3}{*}{ Species } & \multicolumn{7}{|c|}{ Relative abundance by year } \\
\hline & \multirow[b]{2}{*}{ Total obs. } & \multicolumn{3}{|c|}{$2003(n=40)$} & \multicolumn{3}{|c|}{$2004(n=48)$} \\
\hline & & Sum & Mean & SE & Sum & Mean & SE \\
\hline Gambel's quail & 101 & 27 & 0.68 & 0.169 & 30 & 0.63 & 0.128 \\
\hline turkey vulture & 21 & & & & 2 & 0.04 & 0.029 \\
\hline Cooper's hawk & 8 & 5 & 0.13 & 0.082 & 2 & 0.04 & 0.029 \\
\hline zone-tailed hawk & 1 & & & & & 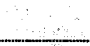 & \\
\hline red-tailed hawk & 4 & & & & & & \\
\hline golden eagle & 1 & & & & & 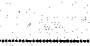 & \\
\hline white-winged dove & 122 & 22 & 0.55 & 0.101 & 34 & 0.71 & 0.126 \\
\hline mourning dove & 84 & 15 & 0.38 & 0.117 & 43 & 0.90 & 0.158 \\
\hline white-throated swift & 7 & & & & & 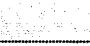 & \\
\hline black-chinned hummingbird & 8 & 3 & 0.08 & 0.042 & & & \\
\hline broad-tailed hummingbird & 14 & 1 & 0.03 & 0.025 & 4 & 0.08 & 0.040 \\
\hline ladder-backed woodpecker & 23 & 5 & 0.13 & 0.053 & 8 & 0.17 & 0.062 \\
\hline greater pewee & 1. & & & & & 3 & \\
\hline western wood-pewee & 6 & 2 & 0.05 & 0.035 & & & \\
\hline gray flycatcher & 2 & & & & 1 & 0.02 & 0.021 \\
\hline dusky-capped flycatcher & 1 & & & & & & \\
\hline ash-throated flycatcher & 54 & 25 & 0.63 & 0.142 & 14 & 0.29 & 0.079 \\
\hline brown-crested flycatcher & 3 & 1 & 0.03 & 0.025 & & & \\
\hline Cassin's kingbird & 61 & 8 & 0.20 & 0.082 & 33 & 0.69 & 0.130 \\
\hline western kingbird & 13 & 3 & 0.08 & 0.055 & 5 & 0.10 & 0.054 \\
\hline Bell's vireo & 14 & 5 & 0.13 & 0.082 & 6 & 0.13 & 0.048 \\
\hline plumbeous vireo & 2 & & 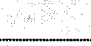 & & 2 & 0.04 & 0.029 \\
\hline warbling vireo & 3 & & & & & 18 & \\
\hline curve-billed thrasher & 8 & 1 & 0.03 & 0.025 & 5 & 0.10 & 0.054 \\
\hline crissal thrasher & 18 & & & & 11 & 0.23 & 0.068 \\
\hline western scrub-jay & 22 & 8 & 0.20 & 0.082 & 12 & 0.25 & 0.082 \\
\hline Mexican jay & 1 & & & & & & \\
\hline unknown raven & 17 & & & & & & \\
\hline violet-green swallow & 5 & & & & & 3 & \\
\hline verdin & 32 & 15 & 0.38 & 0.078 & 9 & 0.19 & 0.057 \\
\hline bushtit & 5 & 2 & 0.05 & 0.050 & 11 & 0.23 & 0.124 \\
\hline cactus wren & 71 & 19 & 0.48 & 0.095 & 33 & 0.69 & 0.130 \\
\hline rock wren & 2 & & & & 1 & 0.02 & 0.021 \\
\hline canyon wren & 3 & & & & 1 & 0.02 & 0.021 \\
\hline Bewick's wren & 57 & 10 & 0.25 & 0.069 & 28 & 0.58 & 0.111 \\
\hline house wren & 2 & 1 & 0.03 & 0.025 & & 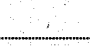 & \\
\hline ruby-crowned kinglet & 13 & 6 & 0.15 & 0.057 & 6 & 0.13 & 0.057 \\
\hline blue-gray gnatcatcher & 4 & 1 & 0.03 & 0.025 & 2 & 0.04 & 0.029 \\
\hline American robin & 1 & 1 & 0.03 & 0.025 & & $\square$ & \\
\hline northern mockingbird & 72 & 14 & 0.35 & 0.084 & 35 & 0.73 & 0.139 \\
\hline phainopepla & 10 & & 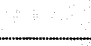 & & 6 & 0.13 & 0.048 \\
\hline Lucy's warbler & 14 & 1 & 0.03 & 0.025 & 13 & 0.27 & 0.071 \\
\hline yellow-rumped warbler & 4 & 1 & 0.03 & 0.025 & 1 & 0.02 & 0.021 \\
\hline black-throated gray warbler & 4 & & & & 3 & 0.06 & 0.046 \\
\hline Townsend's warbler & 1 & & & & 1 & 0.02 & 0.021 \\
\hline Wilson's warbler & 8 & 2 & 0.05 & 0.035 & 2 & 0.04 & 0.029 \\
\hline
\end{tabular}




\begin{tabular}{|c|c|c|c|c|c|c|c|}
\hline \multirow[b]{3}{*}{ Species } & \multicolumn{7}{|c|}{ Relative abundance by year } \\
\hline & \multirow[b]{2}{*}{ Total obs. } & \multicolumn{3}{|c|}{$2003(n=40)$} & \multicolumn{3}{|c|}{$2004(n=48)$} \\
\hline & & Sum & Mean & $\overline{S E}$ & Sum & Mean & $\overline{\mathrm{SE}}$ \\
\hline summer tanager & 31 & 4 & 0.10 & 0.048 & 13 & 0.27 & 0.088 \\
\hline western tanager & 7 & 1 & 0.03 & 0.025 & & & \\
\hline green-tailed towhee & 8 & 6 & 0.15 & 0.057 & 1 & 0.02 & 0.021 \\
\hline spotted towhee & 7 & 3 & 0.08 & 0.042 & 3 & 0.06 & 0.046 \\
\hline canyon towhee & 40 & 20 & 0.50 & 0.139 & 26 & 0.54 & 0.111 \\
\hline Botteri's sparrow & 1 & 1 & 0.03 & 0.025 & & & \\
\hline rufous-crowned sparrow & 14 & 2 & 0.05 & 0.035 & 6 & 0.13 & 0.064 \\
\hline chipping sparrow & 2 & 1 & 0.03 & 0.025 & & & \\
\hline Brewer's sparrow & 2 & 4 & 0.10 & 0.078 & & & \\
\hline black-throated sparrow & 40 & 7 & 0.18 & 0.071 & 22 & 0.46 & 0.123 \\
\hline Oregon junco & 1 & 1 & 0.03 & 0.025 & & & \\
\hline northern cardinal & 112 & 38 & 0.95 & 0.129 & 56 & 1.17 & 0.113 \\
\hline pyrrhuloxia & 1 & 1 & 0.03 & 0.025 & & & \\
\hline black-headed grosbeak & 7 & & & & 1 & 0.02 & 0.021 \\
\hline blue grosbeak & 2 & 2 & 0.05 & 0.050 & 1 & 0.02 & 0.021 \\
\hline lazuli bunting & 1 & & & & 1 & 0.02 & 0.021 \\
\hline bronzed cowbird & 1 & 2 & 0.05 & 0.050 & & & \\
\hline brown-headed cowbird & 33 & 5 & 0.13 & 0.053 & 13 & 0.27 & 0.077 \\
\hline hooded oriole & 36 & 15 & 0.38 & 0.111 & 13 & 0.27 & 0.083 \\
\hline Bullock's oriole & 25 & 6 & 0.15 & 0.067 & 11 & 0.23 & 0.074 \\
\hline Scott's oriole & 6 & 2 & 0.05 & 0.035 & 3 & 0.06 & 0.035 \\
\hline house finch & 40 & 8 & 0.20 & 0.073 & 14 & 0.29 & 0.079 \\
\hline lesser goldfinch & 3 & & & & 2 & 0.04 & 0.029 \\
\hline
\end{tabular}

\section{Nocturnal Surveys}

We recorded four species of nocturnal birds: one observation each of the western screech owl and great-horned owl, three observations of the elf owl, and 12 observations of the common poorwill.

\section{Incidental and Breeding Observations}

We made incidental observations of 72 species, including 12 species that were not detected during any other survey type (Appendix C). These species included: long-eared owl, common ground dove, greater roadrunner, Bendire's thrasher, Baird's sparrow, and grasshopper sparrow. We made 84 observations of breeding behavior, representing 32 species (Table 4.6). We made the most breeding observations of mourning dove (14 observations). We confirmed breeding for Bell's vireo and summer tanager, two riparian-obligate species.

\section{Inventory Completeness}

Based on the results from our surveys and the list by Fischer (2002), the inventory of birds that regularly use the park is probably close to completion. A look at the species accumulation curve for our work indicates that our effort alone was not sufficient to document all of the species that occur in the park; the cumulative number of new species for this study was not approaching an asymptote (Fig. 4.3). We found 6 species that were new to the park list: Baird's sparrow, Hutton's vireo, common ground-dove, dusky-capped flycatcher, greater pewee, and zone-tailed hawk (Appendix C). Of these species, only Hutton's vireo may nest at the park. Because of the location of the park near to the species-rich Chiricahua Mountains (one of the most popular destinations in the United States for bird watchers), we expect that new species of birds will be added to the list for years to come, but that these species will likely be uncommon or rare at the park. Only through major modification of the vegetation community (either by the use of fire or removal of mesquite) will additional species, such as grassland-associated sparrows (e.g., grasshopper, Cassin's, and Botteri's), nest in the park. 
Table 4.4. Total number of observations (Total obs.) and relative abundance (mean $\pm \mathrm{SE}$ ) of birds during VCP surveys, Butterfield transect, Fort Bowie NHS, 2004. Total number of observations includes all birds observed during surveys whereas relative abundance estimates exclude birds observed $>75 \mathrm{~m}$ from stations, flyovers, and observations made outside of the eightminute count period. Sum is the number of observations used in calculating relative abundance estimates. See Methods section for additional details on estimation of relative abundance and Table 4.2 for sample size.

\begin{tabular}{|c|c|c|c|c|}
\hline \multirow[b]{2}{*}{ Species } & \multirow[b]{2}{*}{ Total obs. } & \multicolumn{3}{|c|}{ Relative abundance $(n=48)$} \\
\hline & & Sum & Mean & SE \\
\hline Gambel's quail & 34 & 7 & 0.15 & 0.089 \\
\hline turkey vulture & 17 & 1 & 0.02 & 0.021 \\
\hline red-tailed hawk & 3 & & $2+3$ & \\
\hline white-winged dove & 38 & 2 & 0.04 & 0.029 \\
\hline mourning dove & 71 & 15 & 0.31 & 0.095 \\
\hline black-chinned hummingbird & 3 , & & 40 & \\
\hline ladder-backed woodpecker & 20 & 8 & 0.17 & 0.069 \\
\hline western wood-pewee & 1 & & 140\% & \\
\hline Hammond's flycatcher & 1 & 1 & 0.02 & 0.021 \\
\hline ash-throated flycatcher & 42 & 19 & 0.40 & 0.093 \\
\hline Cassin's kingbird & 6 & & 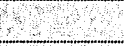 & \\
\hline western kingbird & 1 & & 58 & \\
\hline crissal thrasher & 12 & 8 & 0.17 & 0.062 \\
\hline western scrub-jay & 17 & 5 & 0.10 & 0.045 \\
\hline unknown raven & 5 & & 518 & \\
\hline bridled titmouse & 1 & 1 & 0.02 & 0.021 \\
\hline juniper titmouse & 3 & 4 & 0.08 & 0.065 \\
\hline verdin & 2 & 2 & 0.04 & 0.029 \\
\hline bushtit & 4 & 11 & 0.23 & 0.124 \\
\hline cactus wren & 39 & 23 & 0.48 & 0.094 \\
\hline rock wren & 7 & 4 & 0.08 & 0.050 \\
\hline Bewick's wren & 50 & 32 & 0.67 & 0.113 \\
\hline ruby-crowned kinglet & 2 & 2 & 0.04 & 0.029 \\
\hline northern mockingbird & 28 & 4 & 0.08 & 0.050 \\
\hline phainopepla & 4 & 3 & 0.06 & 0.046 \\
\hline Lucy's warbler & 3 & 1 & 0.02 & 0.021 \\
\hline green-tailed towhee & 1 & 1 & 0.02 & 0.021 \\
\hline canyon towhee & 36 & 31 & 0.65 & 0.117 \\
\hline rufous-crowned sparrow & 29 & 17 & 0.35 & 0.070 \\
\hline chipping sparrow & -1 & 1 & 0.02 & 0.021 \\
\hline black-throated sparrow & 67 & 47 & 0.98 & 0.141 \\
\hline northern cardinal & 2 & & 12 & \\
\hline black-headed grosbeak & 5 & & 68 & \\
\hline blue grosbeak & 3 & 3 & 0.06 & 0.046 \\
\hline brown-headed cowbird & 18 & 11 & 0.23 & 0.068 \\
\hline Scott's oriole & 18 & 10 & 0.21 & 0.073 \\
\hline house finch & 10 & 2 & 0.04 & 0.029 \\
\hline
\end{tabular}


Table 4.5. Relative abundance of birds observed during line-transect surveys, Fort Bowie NHS, 2002 and 2003.

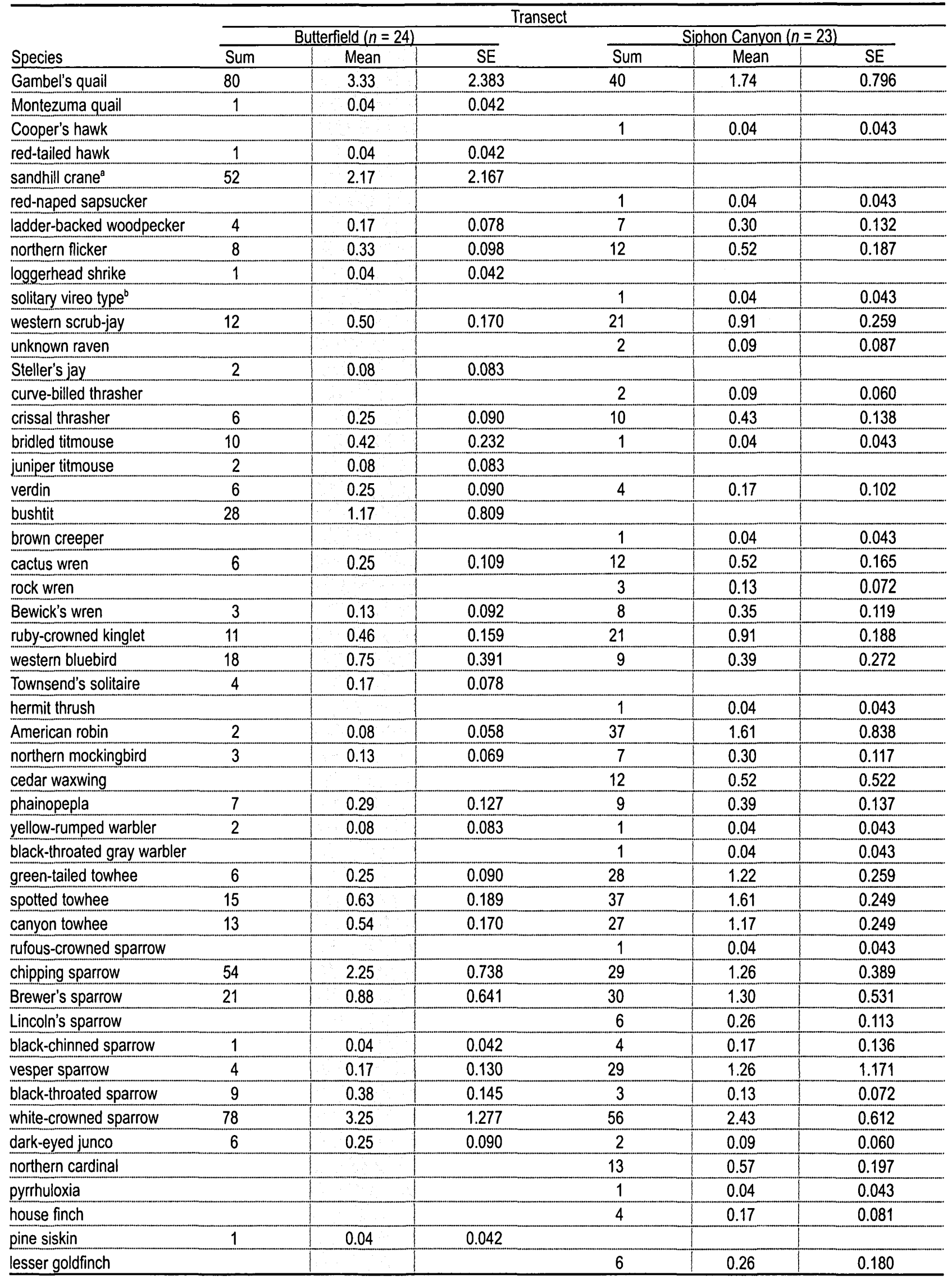

${ }^{\mathrm{a}}$ All observed flying over the park on one occasion.

${ }^{b}$ Either solitary or cordilleran. 
Table 4.6. Number of observations by breeding behavior for birds, Fort Bowie NHS, 2003 and 2004. Breeding behaviors follow standards set by NAOAC (1990).

\begin{tabular}{|c|c|c|c|c|c|c|c|c|c|c|}
\hline \multirow[b]{2}{*}{ Common name } & \multicolumn{4}{|c|}{ Nest } & \multicolumn{2}{|c|}{ Adults carrying } & \multicolumn{3}{|c|}{ Other } & \multirow[b]{2}{*}{ Totals } \\
\hline & Building & $\begin{array}{l}\text { With } \\
\text { eggs }\end{array}$ & $\begin{array}{l}\text { With } \\
\text { young }\end{array}$ & Occupied & Food & $\begin{array}{l}\text { Nesting } \\
\text { material }\end{array}$ & $\begin{array}{c}\text { Distraction } \\
\text { displays }\end{array}$ & $\begin{array}{l}\text { Feeding } \\
\text { recently } \\
\text { fledged } \\
\text { young }\end{array}$ & $\begin{array}{c}\text { Recently } \\
\text { fledged } \\
\text { young }\end{array}$ & \\
\hline Gambel's quail & & & & & & & & 1 & 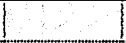 & 1 \\
\hline Cooper's hawk & & & & 2 & & & & & & 2 \\
\hline white-winged dove & & 1 & & 4 & & & & & & 5 \\
\hline mourning dove & & & & 14 & & & & & & 14 \\
\hline & & & & & & & & & & \\
\hline black-chinned hummingbird & & & & 1 & & & 0 & & & 1 \\
\hline broad-tailed hummingbird & 1 & & & 3 & & & 2 & & - & 6 \\
\hline ladder-backed woodpecker & & & & 1 & & & & & & 1 \\
\hline Say's phoebe & & & & & & & & 2 & 1 & 3 \\
\hline brown-crested flycatcher & & & & 1 & & & 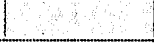 & & & 1 \\
\hline Cassin's kingbird & 1 & & & 2 & & & 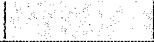 & & 1 & 4 \\
\hline western kingbird & & & & & & & 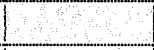 & 1 & 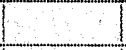 & 1 \\
\hline Bell's vireo & & & & 1 & & & 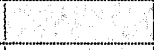 & 1 & 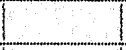 & 2 \\
\hline western scrub-jay & & & & & & & & & 1 & 1 \\
\hline barn swallow & 1 & & & & & & & & & 1 \\
\hline verdin & 1 & & & & & & & & & 1 \\
\hline cactus wren & & & 1 & 1 & 1 & & 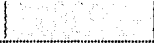 & 2 & & 4 \\
\hline rock wren & & & 1 & & 1 & & 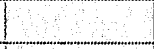 & & & 1 \\
\hline canyon wren & & & 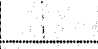 & & 1 & & & 1 & & 2 \\
\hline Bewick's wren & & & & & 1 & & + & & 1 & 2 \\
\hline black-tailed gnatcatcher & & & & & & & & 1 & & 1 \\
\hline northern mockingbird & & & & & 1 & & $=$ & 2 & 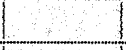 & 3 \\
\hline curve-billed thrasher & & & & & & & & & 1 & 1 \\
\hline crissal thrasher & & & & & & & & & 1 & 1 \\
\hline phainopepla & & & & 1 & & & & & & 1 \\
\hline summer tanager & & & & & & & 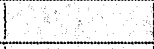 & 2 & & 2 \\
\hline canyon towhee & & & & 1 & 2 & 2 & & 1 & 1 & 7 \\
\hline black-throated sparrow & & & 1 & & 1 & & $\because$ & 1 & & 4 \\
\hline northern cardinal & & & & 1 & 1 & & 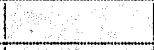 & & 1 & 3 \\
\hline brown-headed cowbird & & & & & & & & & 1 & 1 \\
\hline hooded oriole & 1 & & & 1 & & 1 & & & & 3 \\
\hline Bullock's oriole & & & 1 & 1 & & & & 1 & & 3 \\
\hline house finch & & & & 1 & & & 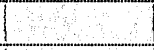 & & & 1 \\
\hline Totals & 5 & 1 & 2 & 35 & 10 & 3 & 2 & 16 & 9 & 84 \\
\hline
\end{tabular}

\section{Discussion}

Based on our research and that by others, Fort Bowie NHS has a diverse bird community $(n=189$ species) for a small area (405 ha) with little topographic relief. Although the pattern of extraordinary species richness that we observed in plants (Chapter 3) was not mirrored in the bird community, the diversity of vegetation communities at the sites clearly plays a role in determining the bird community. For example, there were notable differences in the bird communities along the two repeat-visit VCP transects where the Siphon Canyon transect had almost twice as many species as the Butterfield transect (Tables 4.3, 4.4).

Many of the species that we found in the Siphon Canyon transect are known to occur primarily in riparian areas or areas of dense vegetation: Bell's vireo, summer tanager, hooded 


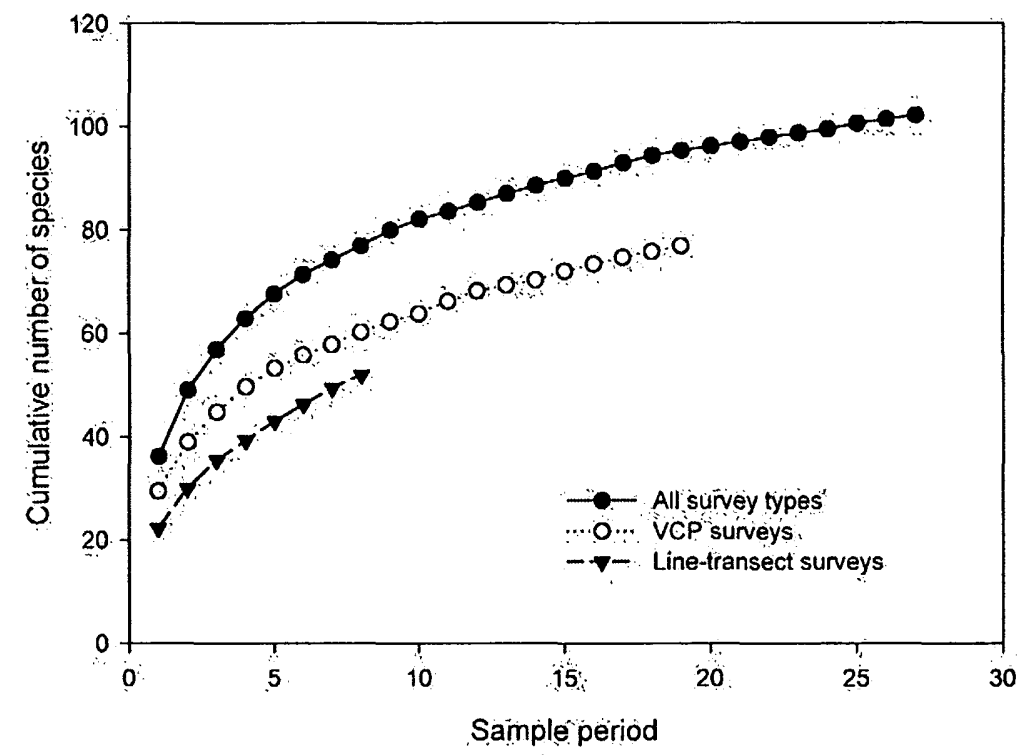

Figure 4.3. Species accumulation curves, by survey type, for the UA bird inventory effort, Fort Bowie NHS, 2002-2004. Each sample period for all survey types represents a randomized ordering of 101 observations $(N=2,821$; a completely randomized combination of the four survey types). Each sample period for VCP and line-transect surveys represents one survey day.

oriole, and northern cardinal (Powell and Steidl 2000). Although not as species rich as in Siphon Canyon, the bird community along the Butterfield transect had species that are associated with the oak savanna and chaparral including juniper titmouse, Crissal thrasher, and rufous-crowned sparrow. Each bird species is closely tied to gross vegetation characteristics such as (1) vertical structure (MacArthur and MacArthur 1961, Cody 1981), (2) horizontal patchiness (Roth 1976, Kotliar and Weins 1990), and (3) floristics (Rice et al. 1984, Strong and Bock 1990, Powell and Steidl 2002). Given the differences in vegetation structure and composition between the two transects, the differences that we noted in the bird communities were not surprising.

The dense riparian vegetation near Apache Spring plays an important role in providing nesting habitat for Cooper's hawk and summer tanager; they were found nesting in that area. Research in the southwestern U.S. has consistently shown that areas with riparian trees have bird communities that are more diverse than adjacent sites (Carothers et al. 1974, Szaro and Jakle 1985, Strong and Bock 1990), which is due, in part, to the variety of microhabitats that riparian vegetation provides for nesting (Powell and Steidl 2002), cover, and foraging.

Park managers are interested in the impact that the invasion of the native velvet mesquite is having on the visitors experience in the park (NPS $2000 \mathrm{~b}$ ) because mesquite was not identified in historic photographs of the area. Velvet mesquite has increased in density and distribution in the region since the late $1800 \mathrm{~s}$, primarily due to disruption of historical fire regimes and the introduction of cattle grazing (Humphrey 1974, Brown 1994, Van Auken 2000). The conversion of semi-desert grasslands to mesquite woodlands has important implications for the bird community by favoring shrub-associated species such as northern cardinal, verdin, and black-throated sparrow (Lloyd et al. 1998) while not favoring many species of management concern such as Botteri's, Cassin's, and grasshopper sparrows. The loss of native grassland has been identified as a primary factor in population declines of grassland birds as a group (Herkert 1994, Knopf 1994, Peterjohn and Sauer 1999).

\section{Comparisons to Russell and Johnson (1976)}

The research by Russell and Johnson (1976) was the first comprehensive survey of birds at the park. 
Unfortunately we can only make very gross comparisons between our two studies because we did not use the same survey methods and exactly the same area. Yet a number of species and communities were quite different between the two studies. We found 14 species that Russell and Johnson did not find and they found 62 species that we did not find (Appendix C). We found blackthroated sparrow to be among the most common species in the oak-juniper woodland, but Russell and Johnson did not find them to be very abundant (Appendix G). Conversely, in Siphon Canyon, they found black-chinned hummingbird to be the most common species, whereas it was among the least common species in 2003 and was not found at all in 2004 (Table 4.3). There is little indication of a regional population decline in this species (Sauer et al. 2004), though banding data from Hummingbird
Monitoring Network sites is showing some decline for 2005 (Larry Norris, pers. comm.). Nevertheless, the decline that we saw may have been an artifact of different field methods; species such as hummingbirds may be more conspicuous while walking a transect line.

During the non-breeding season the mesquite-grassland vegetation community had the most bird species that did not rank as abundant for the other study (Appendix G). This may have been an artifact of small sample size from both studies. It could also reflect the variability of non-breeding season birds. For example, species such as whitecrowned, black-throated, Brewer's, and chipping sparrows can form large, sometimes mixed-species flocks which, if encountered, can radically affect the relative abundance estimates for a transect. 


\section{Chapter 5: Mammal Inventory}

\section{Previous Research}

The documented species list of mammals from the park is largely complete. The first inventory of mammals at Fort Bowie was completed by Roth and Cockrum (1976). More recently Petryszyn (1999) and Hermann-Reese (unpublished data) completed surveys for rodents, and Krebbs (2005) surveyed for bats from 2001 to 2004. HermannReese also surveyed for medium and large mammals using infrared-triggered cameras and in this report we summarize that work (Appendix H). Swann et al. (2001) noted mammals seen incidentally to their surveys of reptiles and amphibians. In all, there have been 57 species documented (including specimens at the University of Arizona mammal collection) for the park: 12 bats, 30 small mammals (Orders Insectivora, Rodentia, and Lagomorpha), and 15 medium to large mammals (Orders Carnivora and Artiodactyla; Appendix D).

\section{Methods}

Because mammals have been surveyed extensively, we surveyed only for medium and large mammals using infrared-triggered cameras at three sites (Fig. 5.1). For this report our purpose was to (1) augment the infrared-triggered camera effort of Herman-Reese and (2) synthesize species lists from the previously mentioned survey efforts. We refer the reader to the other inventory efforts for more detailed species accounts.
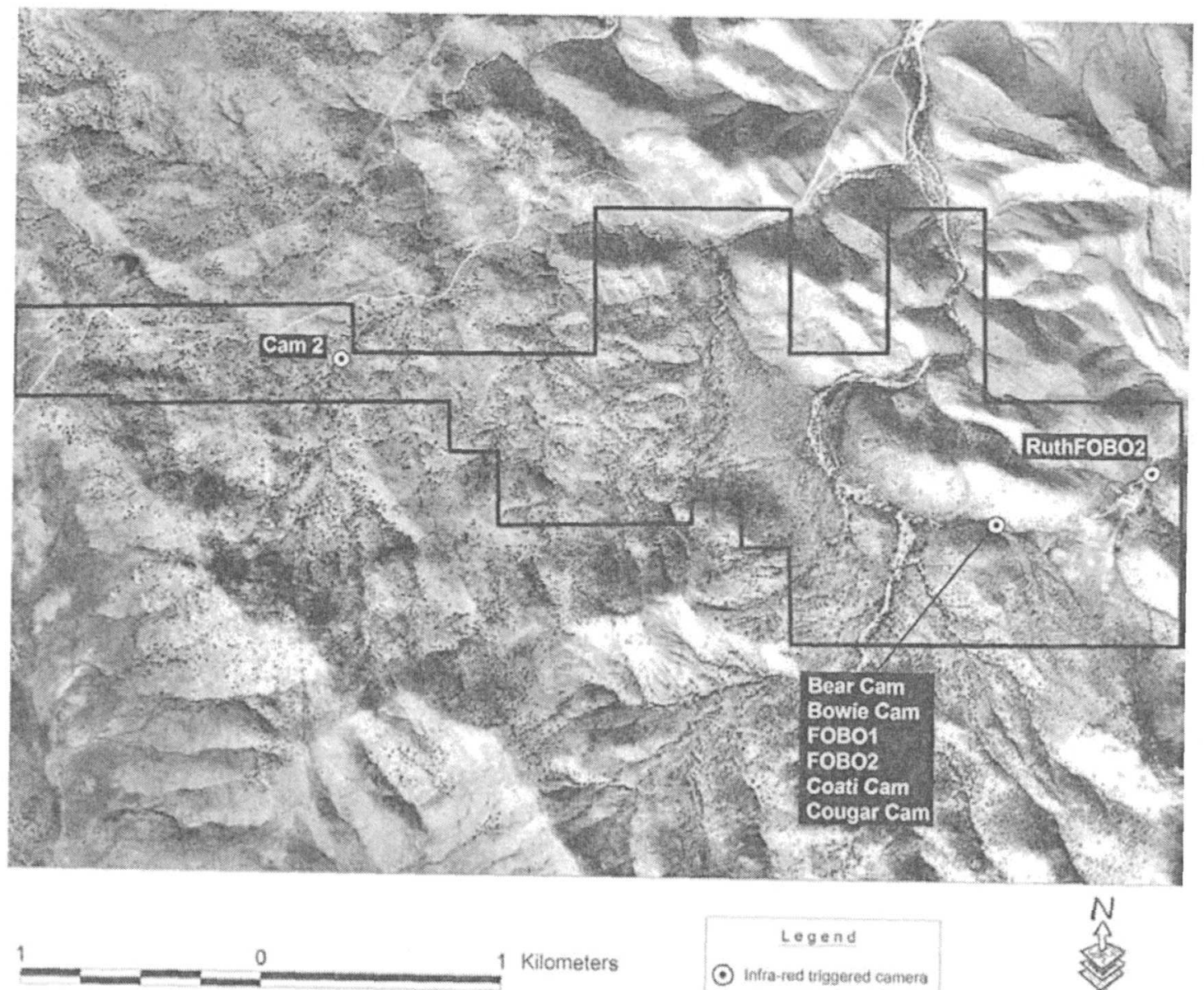

Legend
C. Intra-red triggered camera

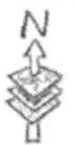

Figure 5.1. Location of Trailmaster camera sites, Fort Bowie NHS, 2002-2003. 


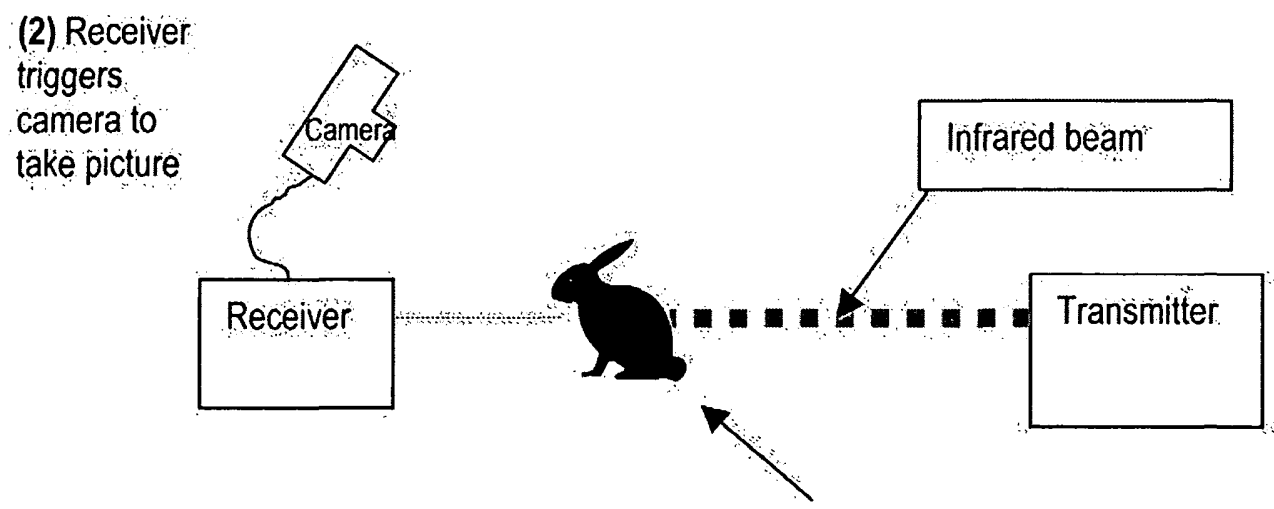

(1) Animal blocks infrared beam from getting to receiver

Figure 5.2. Diagram of infrared-triggered camera (Trailmaster) set-up. Image based on Swann et al. (2004).

\section{Trailmaster Cameras}

We used infrared-triggered cameras (herein referred to as "Trailmaster"; Trailmaster®; model 1500, Goodman and Associates, Inc, Lenexa, KS;

Kucera and Barrett 1993) to record the presence of medium and large mammals. Trailmasters have three components: receiver, transmitter, and camera (Fig. 5.2). The transmitter sends an infrared beam to the receiver at a specified rate ( 5 times per second for this study). The receiver then sends a signal (via cable) to a camera mounted on a tripod 6-8 $\mathrm{m}$ away. When an animal blocks the infrared beam the camera takes a picture.

We set the receiver and transmitter approximately $8 \mathrm{~m}$ apart and $20 \mathrm{~cm}$ above the ground so that medium and large mammals were captured on film but smaller animals such as rodents and birds were not. We set cameras to take no more than one photograph every five minutes to reduce the chances of recording the same individual more than once (on the same occasion). We placed cameras in three areas of the park (Fig. 6.1; UTM coordinates for Willow Gulch $=644390$ N, 3558289 E; Apache Spring $=647101 \mathrm{~N}$, 3557644 E; Visitor Center Road $=647729$ N, $3557866 \mathrm{E}$ ) that we thought would record the highest number of species; typically these were in areas of dense vegetation. We baited camera sites with a commercial scent lure (ingredients included synthetic catnip oil, bobcat musk, beaver castorium, and propylene glycol as a preservative) or canned cat food. We checked cameras approximately every two weeks to change film and batteries and to ensure their proper function. We photographed a placard documenting the date and camera location on the first exposure of every new roll of film.

\section{Spatial Sampling Design}

We selectively placed cameras in areas that we felt would have the most success, primarily near Apache Spring.

\section{Effort}

We operated Trailmaster cameras at three locations from May 2002 to May 2003 for a total of 278 days of camera operation (Table 5.1). Of the three locations, Apache Spring had the most effort (47\%), followed by visitor center road $(38 \%)$ and Willow Gulch (15\%).

\section{Analysis}

Trailmaster cameras are the most cost-effective method for recording the presence of medium and large mammal species (Kucera and Barrett 1993, Cutler and Swann 1999). However, one drawback to this method is an inability to differentiate individuals, which precludes any estimates of abundance (i.e., one must be able to determine whether one animal has been photographed repeatedly or whether more than one individual has been photographed). In some cases, size or physical abnormality may differentiate individuals of any species, but this was not evident in our photographs. Also, each species is more or less likely to be attracted to the camera area. Therefore, we report the number of times a species was photographed to indicate species that may be common, based on the number of photographs. 
Table 5.1. Summary of Trailmaster camera effort, Fort Bowie NHS, 2002 and 2003.

\begin{tabular}{|c|c|c|c|c|c|}
\hline General location & Camera name & Year & Start date & End date & Number of days open \\
\hline \multirow[t]{2}{*}{ Willow Gulch } & Cam 2 & 2002 & $60 \mathrm{Oct}$ & 19 Oct & 13 \\
\hline & & 2002 & 19 Oct & 17 Nov & 29 \\
\hline \multirow[t]{10}{*}{ Apache Spring } & Bowie Cam & 2002 & 12 May & 25 May & 13 \\
\hline & FOBO2 & 2002 & 2 Jun & 16 Jun & $14^{\mathrm{a}}$ \\
\hline & Coati Cam & 2002 & 30 Jun & $7 \mathrm{Jul}$ & $7^{a}$ \\
\hline & Cougar Cam & 2002 & $14 \mathrm{Jul}$ & $21 \mathrm{Jul}$ & $7^{2}$ \\
\hline & & 2002 & $28 \mathrm{Jul}$ & $31 \mathrm{Jul}$ & $3^{a}$ \\
\hline & & 2002 & 22 Sep & 4 Oct & 12 \\
\hline & & 2002 & $19 \mathrm{Oct}$ & $13 \mathrm{Nov}$ & 25 \\
\hline & & 2002 & 17 Nov & $28 \mathrm{Nov}$ & 11 \\
\hline & Bear Cam & 2002 & 25 Aug & $21 \mathrm{Sep}$ & 27 \\
\hline & FOBO1 & 2002 & $6 \mathrm{Oct}$ & 18 Oct & 12 \\
\hline Visitor Center Road & RuthFOBO2 & $2002-2003$ & $19 \mathrm{Dec}$ & 3 May & 105 \\
\hline
\end{tabular}

\section{Incidental Observations and Signs}

As with other taxa, we recorded UTM coordinates of mammal sightings made outside of formal surveys. Observers from all field crews (e.g., bird crew) recorded mammal sightings.

\section{Results and Discussion}

We documented two birds (common black hawk and American robin) and 11 species of mammals using Trailmaster cameras at Fort Bowie NHS in 2002 and 2003 (Table 5.2). We documented two new species of mammals for the park: hooded skunk and feral dog (Appendix D). The photo of the dog is the first documentation of a non-native mammal in the park. The most photographs were of the white-nosed coati (Table 5.2). Collared peccary and striped skunk were also in many of the photographs.

As we expected, most of the photos were from Apache Spring (Table 5.2). In general, this was an extremely dry period (Fig. 2.3) and the spring was an important resource, drawing in many animals including an American black bear, which was likely dispersing from the Pinaleño or Chiricahua Mountains. We did not document any animals at the Willow Gulch site.

Table 5.2. Number of photographs of animals, by Trailmaster camera site, Fort Bowie NHS, 2002 and 2003. Number in parentheses is the total number of individuals if $>1$ individual was seen in a picture.

\begin{tabular}{|c|c|c|c|c|}
\hline \multirow[b]{3}{*}{ Group } & \multirow[b]{3}{*}{ Species } & \multicolumn{3}{|c|}{ Site } \\
\hline & & \multicolumn{2}{|c|}{ Apache Spring } & \multirow{2}{*}{$\begin{array}{c}\text { Visitor Center Road } \\
\begin{array}{c}\text { Number of photographs } \\
\text { and individuals }\end{array} \\
\end{array}$} \\
\hline & & $\begin{array}{l}\text { Number of } \\
\text { photographs }\end{array}$ & $\begin{array}{l}\text { Number of individuals } \\
\text { in photographs }\end{array}$ & \\
\hline \multirow[t]{2}{*}{ Bird } & common black-hawk & 1 & 1 & \\
\hline & American robin & & & 4 \\
\hline \multirow[t]{11}{*}{ Mammal } & American black bear & 4 & 4 & \\
\hline & white-nosed coati & 29 & 55 & \\
\hline & striped skunk & 18 & 19 & 2 \\
\hline & hooded skunk & 2 & 2 & \\
\hline & white-backed hog-nosed skunk & & & 1 \\
\hline & feral dog & 1 & 1 & \\
\hline & common gray fox & 6 & 6 & \\
\hline & mountain lion & 11 & 12 & 2 \\
\hline & bobcat & 6 & 6 & \\
\hline & collared peccary & 15 & 20 & 6 \\
\hline & mule deer & 9 & 12 & \\
\hline
\end{tabular}




\section{Chapter 6: Management Implications}

Based on the data from this study and our knowledge of the natural resource issues at the park, we highlight issues that affect the park's natural resources. Coordination with other agencies, non-governmental organizations, and/or adjacent landowners may prove the best route to resolving some of these challenges.

\section{Development Adjacent to the Park}

One of the most serious threats to the biological diversity of Fort Bowie NHS may be residential development to the north of the park. The development may lead to an increase in the number and extent of non-native plants (Seabloom et al. 2003) and may disrupt animal movement patterns and result in the loss and/or fragmentation of habitat (Mills et al. 1989, Theobald et al. 1997, Riley et al. 2003), particularly for larger mammals. Also, free-roaming pets, normally associated with development, can negatively impact native vertebrates through harassment and mortality (Coleman and Temple 1993). This may not be a problem because the Buddhist retreat, on which most of the adjacent development is taking place, does not allow pets.

\section{Cattle Grazing}

The impact of cattle grazing on the park's natural resources has never been documented. As mentioned in the Park Introduction chapter, cattle grazing can have harmful impacts on the native biota by causing changes in the distribution, abundance, and composition of plant populations as well as soil erosion and compaction. Ruyle (2001) assessed the range condition on eight sites; his results indicate that conditions ranged from fair to good, but those conditions were only assessed using vegetation measures. We suggest that if grazing were to continue at the park, managers establish more long-term monitoring protocols and sites to determine the impact of grazing on the natural resources of the park, particularly soils, vegetation, and vertebrates.

Perhaps the most damaging practice relating to grazing is the use of water from Apache Spring to supply water to adjacent cattle allotments. Although the allotment of one-half of the water from the spring is rarely realized (Larry Ludwig, pers. comm. to Michele Gerard), there is a potential for that amount of water to be diverted. The water from the spring is a vital resource for the park and is responsible for the riparian area that is so valuable for plants and wildlife in the area. A hydrologist could help park managers determine the impact of water diversion on the riparian area.

\section{Visitor Impacts}

If the road over Apache Pass is paved, there will likely be increased mortality of reptiles, particularly snakes, which seek out the pavement on hot summer nights to bask (Rosen and Lowe 1994). Increased vehicular volume and speed will also likely increase the modification of animal behavior (Trombulak and Frissell 2000). Modification of behavior probably already takes place at Apache Spring, which is the only source of perennial water for animals, but is also a popular resting spot for hikers. The effect of this conflict has never been quantified, but given the high abundance and species richness of birds and large mammals in that area (see Tables 4.3, 5.2), conflicts are inevitable. 


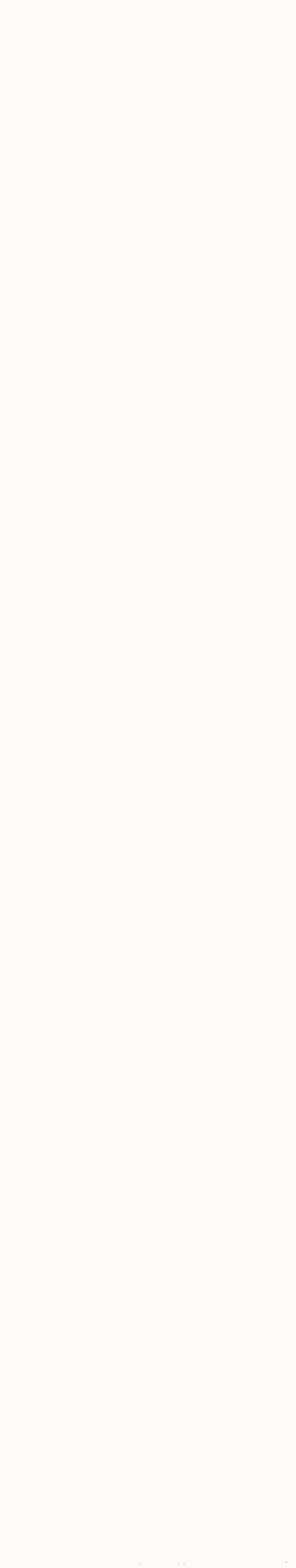




\section{Chapter 7: Additional Inventories}

No inventory is ever truly complete; species distributions expand and contract across boundaries, particularly at smaller parks such as Fort Bowie NHS. In general, we feel that the inventories for vascular plants and vertebrates are nearly complete and that the park is in a good position to monitor changes in species composition. Through the continuous collection of data, such as specimens from road kill, photographs, and through research studies at the park, managers can continue to monitor changes. An additional step would be to coordinate additional inventory-like field efforts with adjacent landowners to increase the spatial scope of the inventory effort. Below we suggest ways to complete the species inventories and/or implement monitoring on the park.

\section{Plants}

A number of woody invasive species such as velvet mesquite and burroweed are of concern to park managers (NPS 2000b) and there is currently a program to remove mesquite. We suggest that a more rigorous, plot-based vegetation monitoring program be established at the park (e.g., Powell et al. 2005a), including a number of plots in the area of mesquite removal. This monitoring would inform the park managers of the effectiveness of the program as well as document changes in the plant community concurrent to this removal (of particular concern is the spread of non-native grasses such as Lehmann lovegrass). Repeat inventories for plants, particularly the early detection of non-native plants, should be carried out at least every five years.

Specimen vouchers from the park may be residing in the herbarium collections at Arizona State University and Northern Arizona University. In early 2005 it became possible to access information about these collections. We suggest that these databases be searched for specimens from the park. However, care should be taken in accepting the list of species without confirming the proper identification of species or updating taxonomy (Halvorson 2003).

Many of the specimens cited in the report by Warren et al. (1992) are currently housed at the park, but because the park does not have a natural resource staff member who is responsible for the proper curation of that collection, it is unlikely that the plant specimens are receiving proper care. Therefore, we recommend removing them to a collection that has proper archival conditions, such as the University of Arizona.

\section{Reptiles and Amphibians}

Swann et al. (2001) surveyed for amphibians and reptiles in 1997 and 1998 and their study remains one of the best examples of a biological inventory in the region. Because they designed their study to form the basis for long-term monitoring, we suggest repeating their effort (or some portion) at least every ten years. It will especially important to survey for amphibians and aquatic reptiles because these groups are experiencing sharp declines in distribution and abundance (Wake 1990).

\section{Birds}

Additional surveys during the winter season and during the spring and fall migrations will pick up species missed by efforts at other times. It is important to note, however, that bird lists are difficult to complete because birds are highly mobile. Only sites that are visited regularly by avid bird watchers (e.g., Madera Canyon, Ramsey Canyon, and Patagonia-Sonoita Creek Preserve in southern Arizona) have bird lists that can be considered to be "complete."

\section{Mammals}

Herman-Reese did not write up the results of either the small mammal trapping or Trailmaster studies that she undertook. Although we published an appendix of her Trailmaster camera results (Appendix $\mathrm{H}$ ), this effort is insufficient to properly document and archive data from that project. We encourage park staff to work with her to complete that effort before too much time passes; her field effort was considerable and it would be unfortunate not to have a report to document her effort.

The one group of mammals that may require additional inventory work is bats. Krebbs (2005) netted at the park from 2001-2004 for a total of five nights of netting. It did not appear to 
be sufficient for documenting all of the species of insectivorous bats at the park; new species continued to be found. We therefore recommend additional netting at Apache Spring. The use of ultrasonic detectors to identify bat species is increasing, and many researchers are refining the field techniques and improving the technology (e.g., Johnson et al. 2002, Gannon et al. 2003). These technologies may become more useful in the coming years with these refinements. 


\section{Chapter 8: Literature Cited}

American Ornithologists' Union (AOU). 1998. Checklist of North American birds, seventh edition. American Ornithologists' Union and Allen Press Inc., Lawrence, KS.

American Ornithologists' Union (AOU). 2003. Forty-second supplement to the American Ornithologists' Union checklist of North American birds. Auk 117:847-858.

Anable, M. E., M. P. McClaren, and G. B. Ruyle. 1992. Spread of introduced Lehmann's lovegrass Eragrostis lehmanniana Nees. in southern Arizona, USA. Biological Conservation 61:181-188.

Anderson, D. R. 2001. The need to get the basics right in wildlife field studies. Wildlife Society Bulletin 29:1294-1297.

Bahre, C. J. 1991. A legacy of change: historic human impact on vegetation of the Arizona borderlands. University of Arizona Press, Tucson, AZ.

Baker, R. J., L. C. Bradley, R. D. Bradley, J. W. Dragoo, M. D. Engstrom, R. S. Hoffmann, C. A. Jones, F. Reid, D. W. Rice, and C. Jones. 2003. Revised checklist of North American mammals north of Mexico, 2003. Occasional Papers of the Museum of Texas Tech University 229:1-23.

Bednarz, J. C., and R. J. Raitt. 2002. Chihuahuan raven (Corvus cryptoleucus). In The birds of North America, No. 606. A. Poole and F. Gill, editors. The Birds of North America, Inc., Philadelphia, PA.

Belsky, A. J., A. Matzke, and S. Uselman. 1999. Survey of livestock influences on stream and riparian ecosystems in the western United States. Journal of Soil and Water Conservation 54:419-431.

Bennett, P. S., R. R. Johnson, and M. R. Kunzman. 1996. An annotated list of vascular plants of the Chiricahua Mountains, Including Pedregosa Mountains, Swisshelm Mountains, Chiricahua National Monument, and Fort Bowie National Historic Site. USGS
Cooperative Park Studies Unit. Special

Report No. 12. School of Natural Resources, University of Arizona, Tucson, AZ

Bibby, C. J., N. D. Burgess, and D. A. Hill. 2000. Bird census techniques. Academic Press, London, England.

Bowers, J. E., and S. P. McLaughlin. 1982. Plant species diversity in Arizona. Madroño 29: 227-233.

Brown, D. E. 1994. Biotic communities: southwestern United States and northwestern Mexico. University of Utah Press, Salt Lake City, UT.

Buckland, S. T., D. R. Anderson, K. P. Burnham, J. L. Laake, D. L. Borchers, and L. Thomas. 2001. Introduction to Distance Sampling: estimating abundance of biological populations. Oxford University Press, London, England.

Bureau of Land Management (BLM). 1994. Rangeland reform 1994. Draft environmental impact statement. U. S. Department of the Interior, Washington, D.C.

Burgess, T. L., J. E. Bowers, and R. M. Turner. 1991. Exotic plants at the Desert Laboratory, Tucson, Arizona. Madroño 38:96-114.

Carothers, S.W., R. R. Johnson, and S.W. Atchinson. 1974. Population structure and social organization of southwestern riparian birds. American Zoologist 14:97-108.

Cody, M. L. 1981. Habitat selection in birds: the roles of vegetation structure, competitors, and productivity. Bioscience 31:107-113.

Coleman, J. S., and S. A. Temple. 1993. Rural residents' free-ranging domestic cats: a survey. Wildlife Society Bulletin 21:381-390.

Colver, K. J., D. Stokes, and L. Stokes. 1999. Stokes field guide to bird songs. Time Warner Trade, New York, NY.

Cutler, T. L., and D. E. Swann. 1999. Using remote photography in wildlife ecology: a review. Wildlife Society Bulletin 27:571-581. 
Davis, K., and W. L. Halvorson. 2000. A study plan to inventory vascular plants and vertebrates: Sonoran Desert Network. Southern Arizona Office, National Park Service, Phoenix AZ.

Denny, D. W., and C. R. Peacock. 2000. Soil Survey of Fort Bowie National Historic Site, Arizona. United States Geological Survey Technical Report No. 64. University of Arizona, Tucson, Arizona.

DeSante, D. F., and D. R. O'Grady. 2000. The monitoring avian productivity and survivorship (MAPS) program: 1997 and 1998 report. Bird Populations 5:49-101.

Farnsworth, G. L., K. H. Pollack, J. D. Nichols, T. R. Simons, J. E. Hines, and J. R. Sauer. 2002. A removal model for estimating detection probabilities from point-count surveys. The Auk 119:414-425.

Fischer, D. 2002. A checklist of birds of Chiricahua National Monument \& Fort Bowie National Historic Site. Southwest Parks and Monuments Association, Tucson, AZ.

Fleischner, T. L. 1994. Ecological costs of livestock grazing in western North America. Conservation Biology 8:629-644.

Fuller, M. R., and J. A. Mosher. 1987. Raptor survey techniques. Pp. 37-66. In B. A. Geron-Pendleton, B. A. Millsap, K. W. Cline, and D. M. Bird, editors. Raptor management techniques manual. National Wildlife Federation, Washington, D.C.

Gannon, W. L., R. E. Sherwin, and S. Haymond. 2003. On the importance of articulating assumptions when conducting acoustic studies of habitat use by bats. Wildlife Society Bulletin 31:45-61.

Halvorson, W. L. 2003. Verification of plant specimens from Sonoran desert parks. Report to the Desert Southwest Cooperative Ecosystems Studies Unit, University of Arizona, Tucson, AZ.

Halvorson, W. L., and P. Guertin. 2003. USGS Weeds in the west project: status of introduced plants in southern Arizona parks. U.S. Geological Survey, Southwest Biological
Science Center, Sonoran Desert Research Station, University of Arizona, Tucson, AZ.

Hartman, E. L., and M. L. Rottman. 1998. A checklist of the vascular plants of Fort Bowie National Historic Site. Unpublished report.

Hayek, L. C., and M. A. Buzas. 1997. Surveying natural populations. Columbia University Press, New York, NY.

Hayes, M. P., and M. R. Jennings. 1986. Decline of Ranid frog species in western North America: are bullfrogs (Rana catesbeiana) responsible? Journal of Herpetology 20:490-509.

Heritage Data Management System (HDMS). 2004. Arizona Game and Fish Department, Phoenix, AZ. Accessed 5 March from: http://www.gf.state.az.us/w_c/edits/hdms_spec ies_lists.html.

Hermann-Reese, B. No Date. Nocturnal rodents survey count, Fort Bowie National Historic Site (1997-2002). Unpublished data to Fort Bowie National Historic Site.

Herkert, J. R. 1994. Breeding bird communities of midwestern prairie fragments - the effects of prescribed burning and habitat-area. Natural Areas Journal 14:128-135.

Humphrey, R. R. 1974. Fire in the deserts and desert grasslands of North America. Pages 365-400 In T. T. Kozlowski, and C. E. Algren, editors. Fire and ecosystems. Academic Press, London, England.

Integrated Taxonomic Information System (ITIS). 2004. Accessed on 20 March 2004 from: http://www.itis.usda.gov/index.html.

Johnson, J. B., M. A. Menzel, J. W. Edwards, and W. M. Ford. 2002. A comparison of 2 acoustical bat survey techniques. Wildlife Society Bulletin 30:931-936.

Kiesecker, J. M., and A. R. Blaustein. 1997. Population differences in responses of redlegged frogs (Rana aurora) to introduced bullfrogs. Ecology 78:1752-1760.

Knopf, F. L. 1994. Avian assemblages on altered grasslands. Studies in avian biology 15:247-257. 
Kotliar, N.B., and J. A. Weins. 1990. Multiple scales of patchiness and patch structure: a hierarchical framework for the study of heterogeneity. Oikos 59:253-260.

Krebbs, K. 2005. Bat species richness and abundance at the Chiricahua National Monument and Fort Bowie Historic Site. Unpublished report to Western National Parks Association and the National Park Service, Tucson, AZ.

Krebs, C. J. 1998. Ecological Methodology. Second Edition. Addison-Welsey Educational, Menlo Park, CA.

Kucera, T. E., and R. H. Barrett. 1993. The Trailmaster camera system for detecting wildlife. Wildlife Society Bulletin 21:505-508.

Lancia, R. A., J. D. Nichols, and K. H. Pollock. 1996. Estimating the number of animals in wildlife populations. Pp. 215-253. In T. A. Bookhout, editor. Research and management techniques for wildlife and habitats. Fifth edition. The Wildlife Society, Bethesda, MD.

Latta, M. J., C. J. Beardmore, and T. E. Corman. 1999. Arizona Partners in Flight conservation plan. Technical Report 142. Nongame and Endangered Wildlife Program, Arizona Game and Fish Department, Phoenix, AZ.

Lawler, S. P., D. Dritz., T. Strange, and M. Holyoak. 1999. Effects of introduced mosquitofish and bullfrogs on the threatened California red-legged frog. Conservation Biology 13:613-622.

Lloyd, J., R. W. Mannan, S. DeStefano, and C. Kirkpatrick. 1998. The effects of mesquite invasion on a southeastern Arizona grassland bird community. Wilson Bulletin 110:403-408.

Lowe, C. H., and T. B. Johnson. 1976. A survey of the reptiles and amphibians of the Fort Bowie National Historic Site. In Survey of vertebrate fauna of Fort Bowie Historic Site, Arizona. Cooperative National Park Resources Studies Unit. Technical Report No. 2. University of Arizona, Tucson, AZ.
MacArthur, R. H., and J. W. MacArthur. 1961. On bird species diversity. Ecology 42:594-598.

Mills, G. S., J. B. Dunning Jr., and J. M. Bates. 1989. Effects of urbanization of breeding bird community structure in southwestern desert habitats. Condor 91:416-428.

National Park Service (NPS). 1992. NPS-75: Natural resources inventory and monitoring guidelines. U.S. Department of the Interior, Washington, D.C.

National Park Service (NPS). 2000a. Annotated checklist of vascular plants for Fort Bowie National Historic Site. Unpublished report.

National Park Service (NPS). 2000b. Natural and cultural resources management plan. Fort Bowie National Historic Site, AZ.

National Park Service (NPS). 2001. Final environmental impact statement general management plan. Fort Bowie National Historic Site, AZ.

National Park Service (NPS). 2003. Resource issues in southern U.S. border parks from drug trafficking and undocumented alien activity. Southern Arizona Office, Phoenix, AZ.

National Park Service (NPS). 2005. NPS Visitation Database Reports. Accessed January 24, 2005 from: http://www2.nature. nps.gov/NPstats/npstats.cfm.

North American Ornithological Atlas Committee (NAOAC). 1990. Handbook for atlasing North American breeding birds. C. Smith, editor. Accessed 13 July 2001 from: http://americanbirding.org/norac/atlascont.htm.

Peterjohn, B. G., and J. R. Sauer. 1999. Population status of North American grassland birds from the North American Breeding Bird Survey, 1966-1996. Studies in Avian Biology 19:27-44.

Petryszyn, Y. 1999. Rodent monitoring at Fort Bowie National Historic Site. Unpublished report to Fort Bowie National Historic Site.

Powell, B. F., and R. J. Steidl. 2000. Nesting habitat and reproductive success of southwestern riparian birds. Condor 102:823-831. 
Powell, B. F., and R. J. Steidl. 2002. Habitat selection by riparian songbirds breeding in southern Arizona. Journal of Wildlife Management 66:1096-1103.

Powell, B. F., E. W. Albrecht, W. L. Halvorson, C. A. Schmidt, P. Anning, and K. Docherty. 2005a. Vascular plant and vertebrate inventory of Tumacácori National Historical Park. USGS Open-File report 2005-1142. U.S. Geological Survey, Southwest Biological Science Center, Sonoran Desert Research Station, University of Arizona, Tucson, AZ.

Powell, B. F., C. A. Schmidt, and W. L. Halvorson. 2005b. Vascular plant and vertebrate inventory of Fort Bowie National Historic Park. Final report to the National Park Service, Sonoran Desert Inventory and Monitoring Program, Tucson, AZ.

Powell, B. F., E. W. Albrecht, and W. L. Halvorson. 2004. Biological inventory report for the Sonoran Desert Network: 2003. Annual Report No. 3. Sonoran Desert Network Inventory Program. U.S. Geological Survey, Sonoran Desert Research Station and School of Natural Resources, University of Arizona, Tucson, AZ.

Powell, B. F., E. W. Albrecht, W. L. Halvorson, and K. Docherty. 2003. Biological inventory report for the Sonoran Desert Network: 2002. Annual Report No. 2. Sonoran Desert Network Inventory Program. U.S. Geological Survey, Sonoran Desert Field Station and School of Natural Resources, University of Arizona, Tucson, AZ.

Ralph, C. J., J. R. Sauer, S. Droege, technical editors. 1995. Monitoring bird populations by point counts. Gen. Tech. Rep. PSW-GTR149. Pacific Southwest Research Station, Forest Service, U.S. Department of Agriculture, Albany, CA.

Rappole, J. H. 1995. The ecology of migrant birds: a neotropical perspective. Smithsonian Institution Press, Washington D.C.

Reynolds, R. T., J. M. Scott, and R. A. Nussbaum. 1980. A variable circular-plot method for estimating bird numbers. Condor 82:309-313.
Rice, J., B. W. Anderson, and R. D. Ohmart. 1984. Comparison of the importance of different habitat attributes to avian community organization. Journal of Wildlife Management 48:895-911.

Riley, S. P. D., R. M. Sauvajot, T. K. Fuller, E. C. York, D. A. Kamradt, C. Bromley, and R. K. Wayne. 2003. Effects of urbanization and habitat fragmentation on bobcats and coyotes in southern California. Conservation Biology 17:566-576.

Rosen, P. C., and C. H. Lowe. 1994. Highway mortality of snakes in the Sonoran desert of southern Arizona. Biological Conservation 68:143-148.

Roth, R. L. 1976. Spatial heterogeneity and bird species diversity. Ecology 57:773-782.

Roth, E. L., and E. L. Cockrum. 1976. A survey of the mammals of the Fort Bowie National Historic Site. In Survey of vertebrate fauna of Fort Bowie Historic Site, Arizona. Technical Report No. 2. Cooperative National Park Resources Studies Unit. University of Arizona, Tucson, AZ.

Russell, S. M. and T. B. Johnson. 1976. A survey of the birds of the Fort Bowie National Historic Site. In Survey of vertebrate fauna of Fort Bowie Historic Site, Arizona. Technical Report No. 2. Cooperative National Park Resources Studies Unit. University of Arizona, Tucson, AZ.

Ruyle, G. B. 2001. Range resources inventory and vegetation monitoring for Fort Bowie National Historic Site. Unpublished report from School of Renewable Natural Resources, University of Arizona, Tucson, AZ.

Saab, V. A., C. E. Bock, T. D. Rich, and D. S. Dobkin. 1995. Livestock grazing effects in western North America. Pp. 311-353. In T. E. Martin and D. M. Finch, editors. Ecology and management of neotropical migratory birds: a synthesis and review of critical issues. Oxford University Press, London, England.

Sauer, J. R., J. E. Hines, and J. Fallon. 2004. The North American Breeding Bird Survey, results and analysis 1966-2003. Version 2004.1. 
Patuxtant Wildlife Research Center, Laurel

MD. http://www.mbr-

pwrc.usgs.gov/bbs/bbs.html.

Schwalbe, C. R., and P. C. Rosen. 1988.

Preliminary report on effects of bullfrogs on wetland herpetofauna in southeastern Arizona. Pp. 166-173. In R. C. Szaro, K. E. Severson, and D. R. Patton, editors. Management of amphibians, reptiles, and small mammals in North America. Gen. Tech. Rep. RM-166, U.S. Department of Agriculture, Forest Service, Rocky Mountain Research Station, Fort Collins, CO.

Seabloom, E. W., E. T. Borer, V. L. Boucher, R. S. Burton, K. L. Cottingham, L. Goldwasser, W. K. Gram, B. E. Kendall, and F. Micheli. 2003. Competition, seed limitation, disturbance, and reestablishment of California native annual forbs. Ecological Applications 13:575-592.

Stebbins, R. C. 2003. A field guide to western reptiles and amphibians. Third edition. Houghton Mifflin, New York, NY.

Stohlgren, T. J., J. F. Quinn, M. Ruggiero, and G. S. Waggoner. 1995. Status of biotic inventories in U.S. national parks. Biological Conservation 71:97-106.

Strong, T. R., and C. E. Bock. 1990. Bird species distribution patterns in riparian habitats in southeastern Arizona. Condor 92:511-519.

Swann, D. E., M. J. Goode, and C. R. Schwalbe. 2001. Inventory and recommendations for long-term monitoring of reptiles and amphibians at Fort Bowie National Historic Site, Arizona. Unpublished report to Southern Arizona Office, National Park Service, Phoenix, Arizona.

Szaro, R. C., and M. D. Jakle. 1985. Avian use of a desert riparian island and its adjacent scrub habitat. Condor 87:511-519.

Theobald, D. M., J. R. Miller, and N. T. Hobbs. 1997. Estimating the cumulative effects of development on wildlife habitat. Landscape and Urban Planning 39:25-36.

Thompson, S. K. 1992. Sampling. John Wiley and Sons, New York, NY.
Trombulak, S. C., and C. A. Frissell. 2000. Review of ecological effects of roads on terrestrial and aquatic communities. Conservation Biology 14:18-30.

United States Department of Agriculture (USDA). 2004. The PLANTS Database, Version 3.5 (http://plants.usda.gov). National Plant Data Center, Natural Resources Conservation Service, Baton Rouge, LA.

Van Auken, O. W. 2000. Shrub invasions of North American semiarid grasslands. Annual Review of Ecology and Systematics 31:197-215.

Verner, J., and L. V. Ritter. 1983. A comparison of transects and point counts in oak-pine woodlands of California. Condor 87:47-68.

Wake, D. B. 1990. Declining amphibian populations. Science 40:418.

Warren, P. L., M. S. Hoy, and W. E. Hoy. 1992. Vegetation and flora of Fort Bowie National Historic Site, Arizona. National Park Service Technical Report NPS/WRUA/NRTR-92/43.

Western Regional Climate Center (WRCC). 2005. Arizona climate sumaries from Bowie, Arizona: http://www.wrcc.dri.edu/summary/ climsmaz.html. 


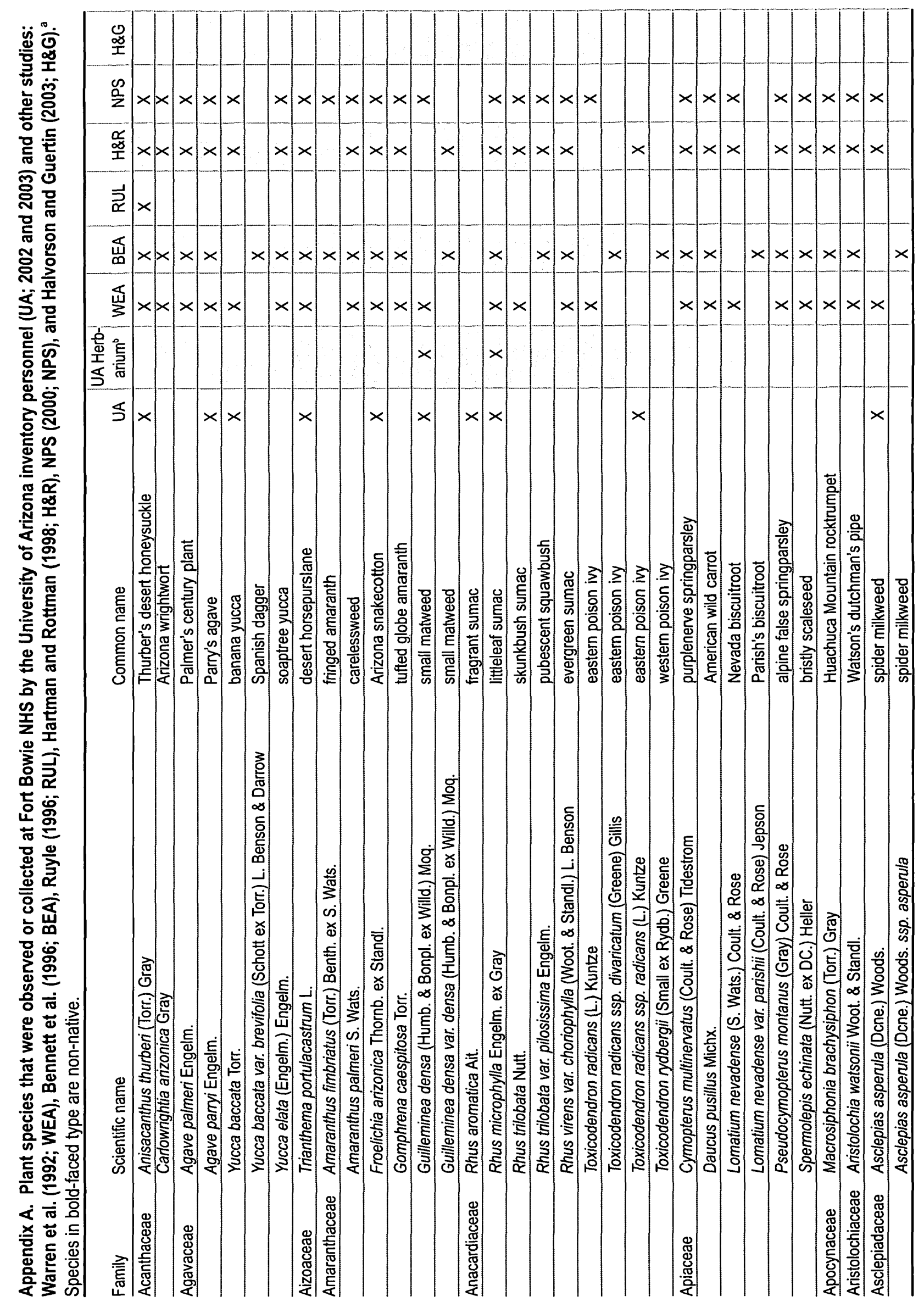




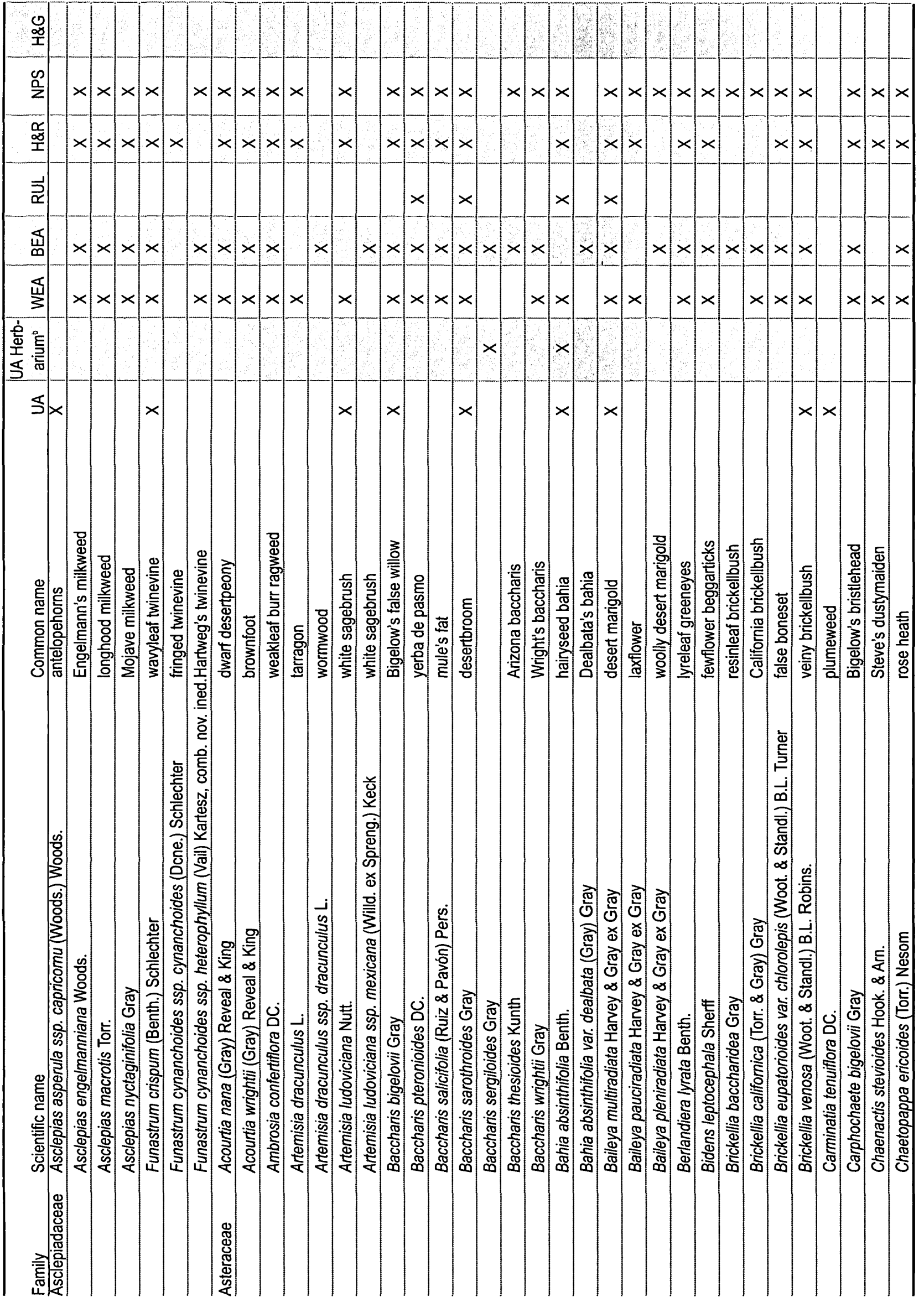




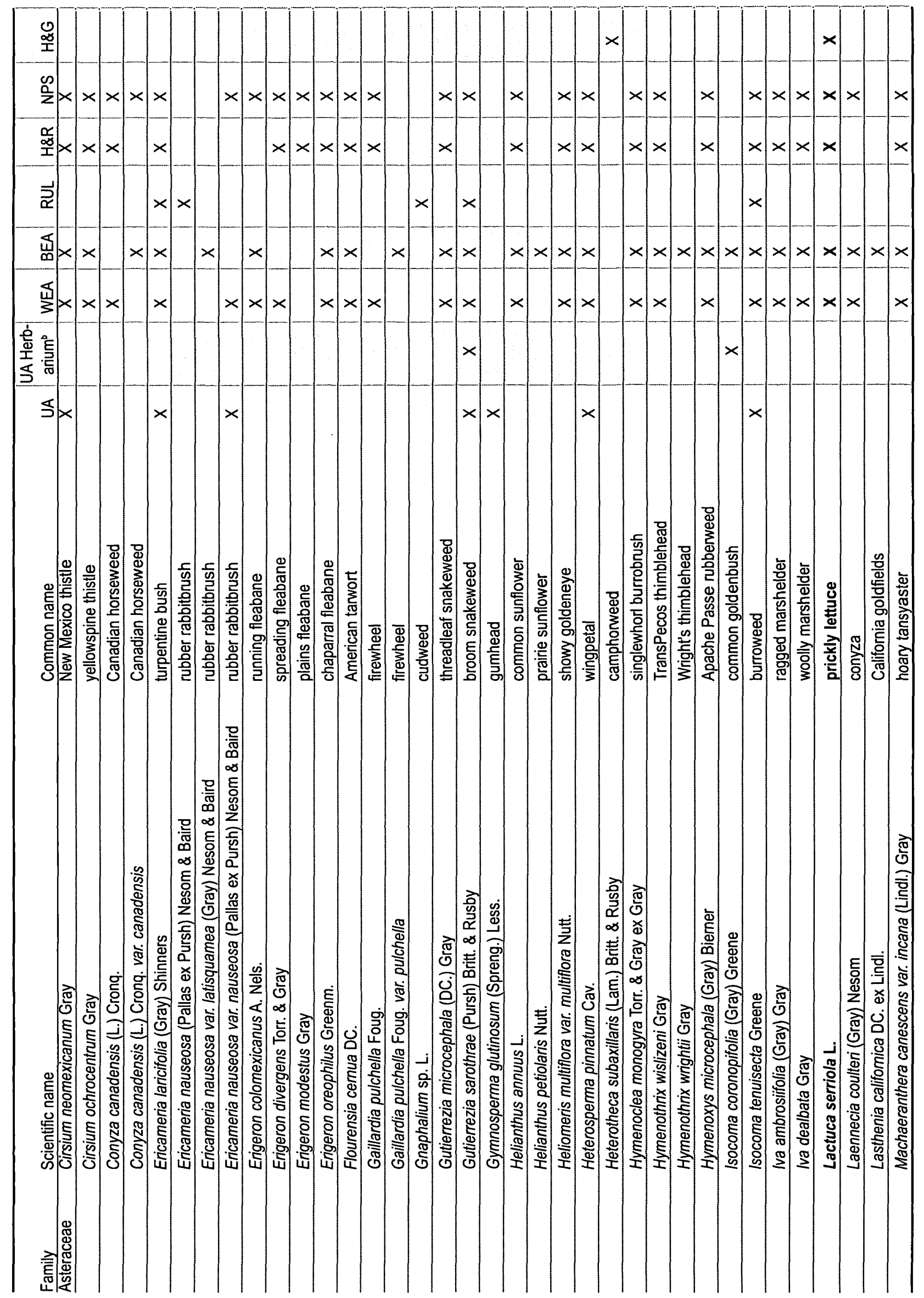




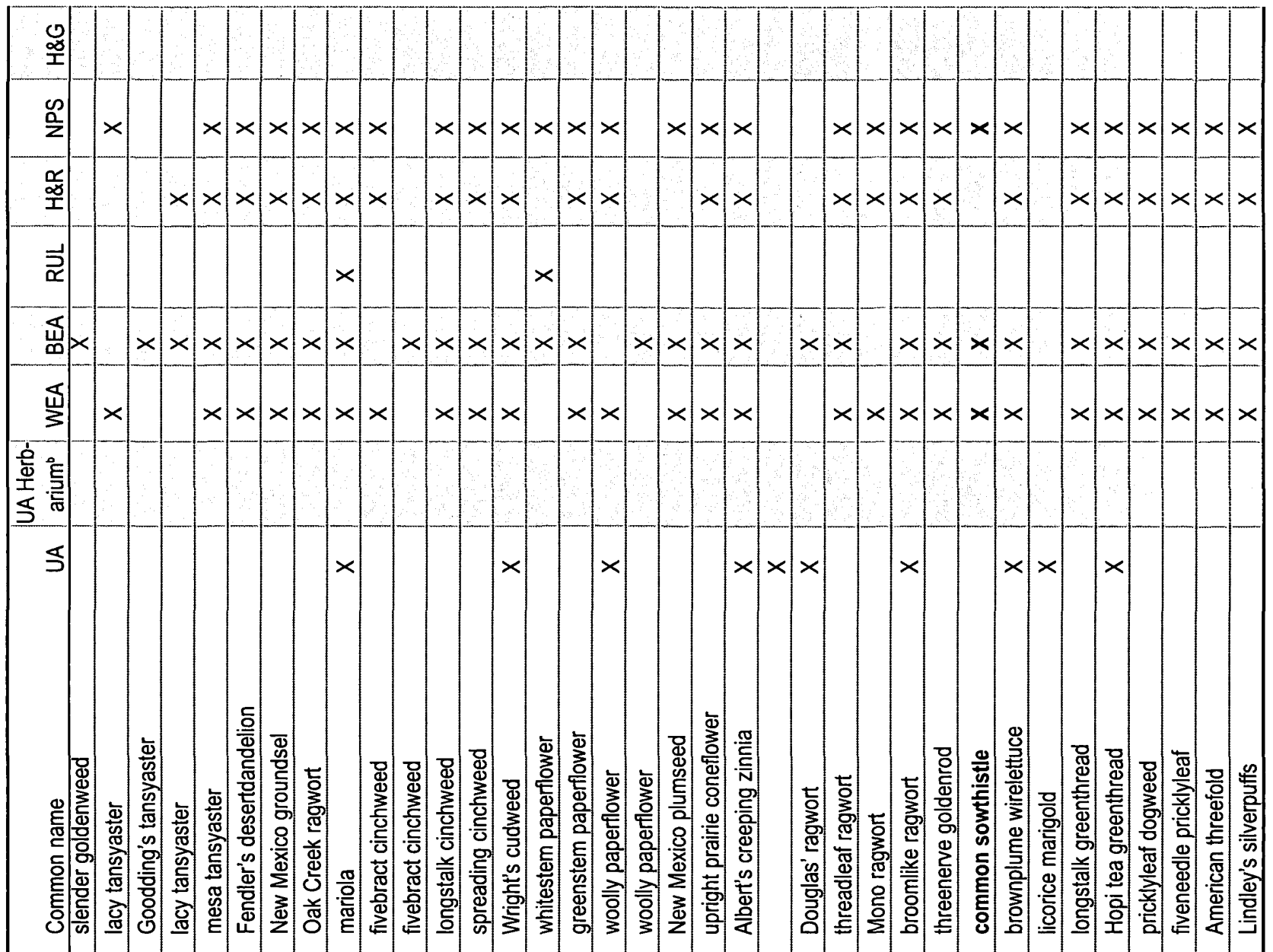

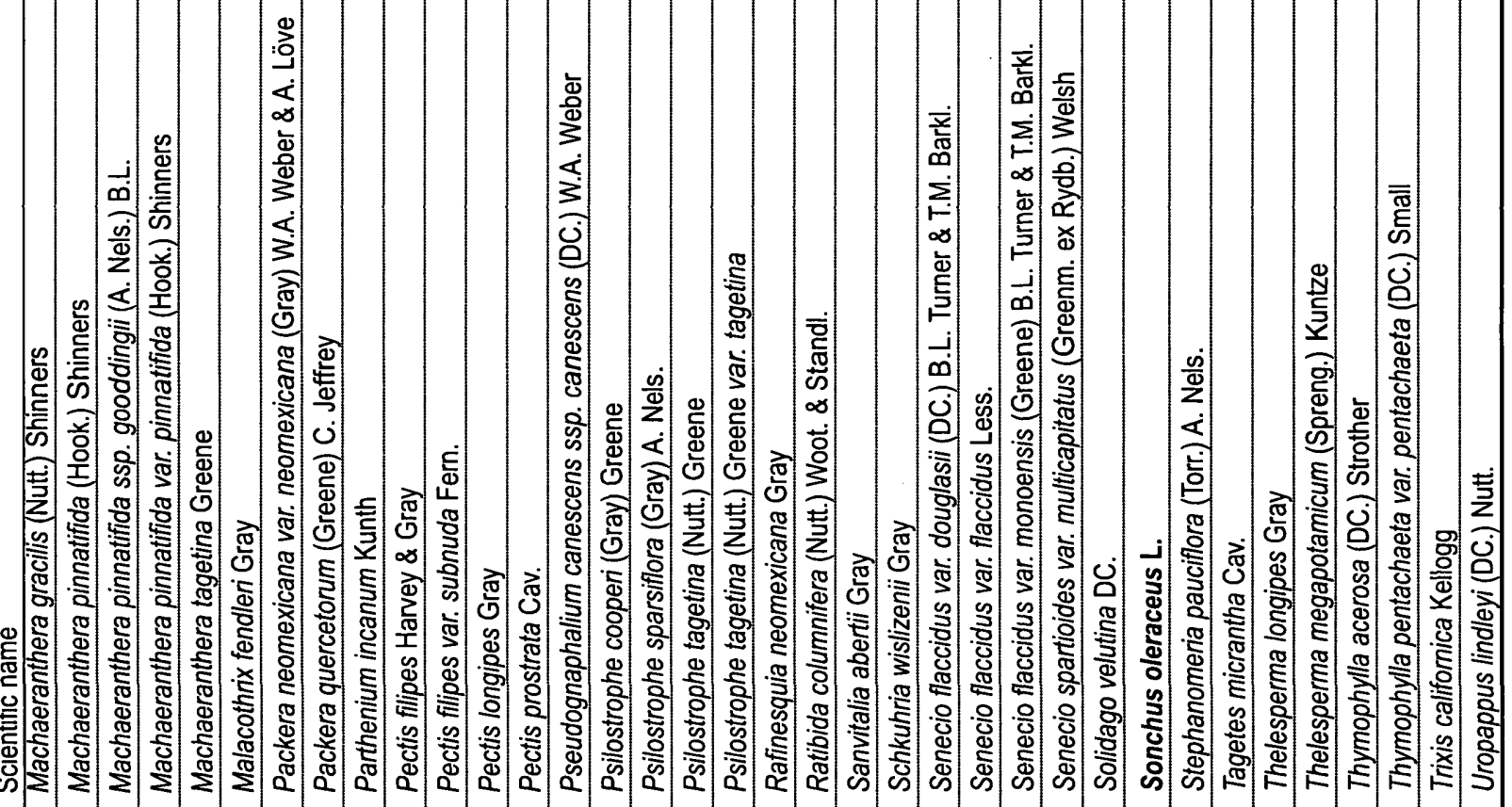

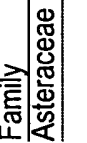




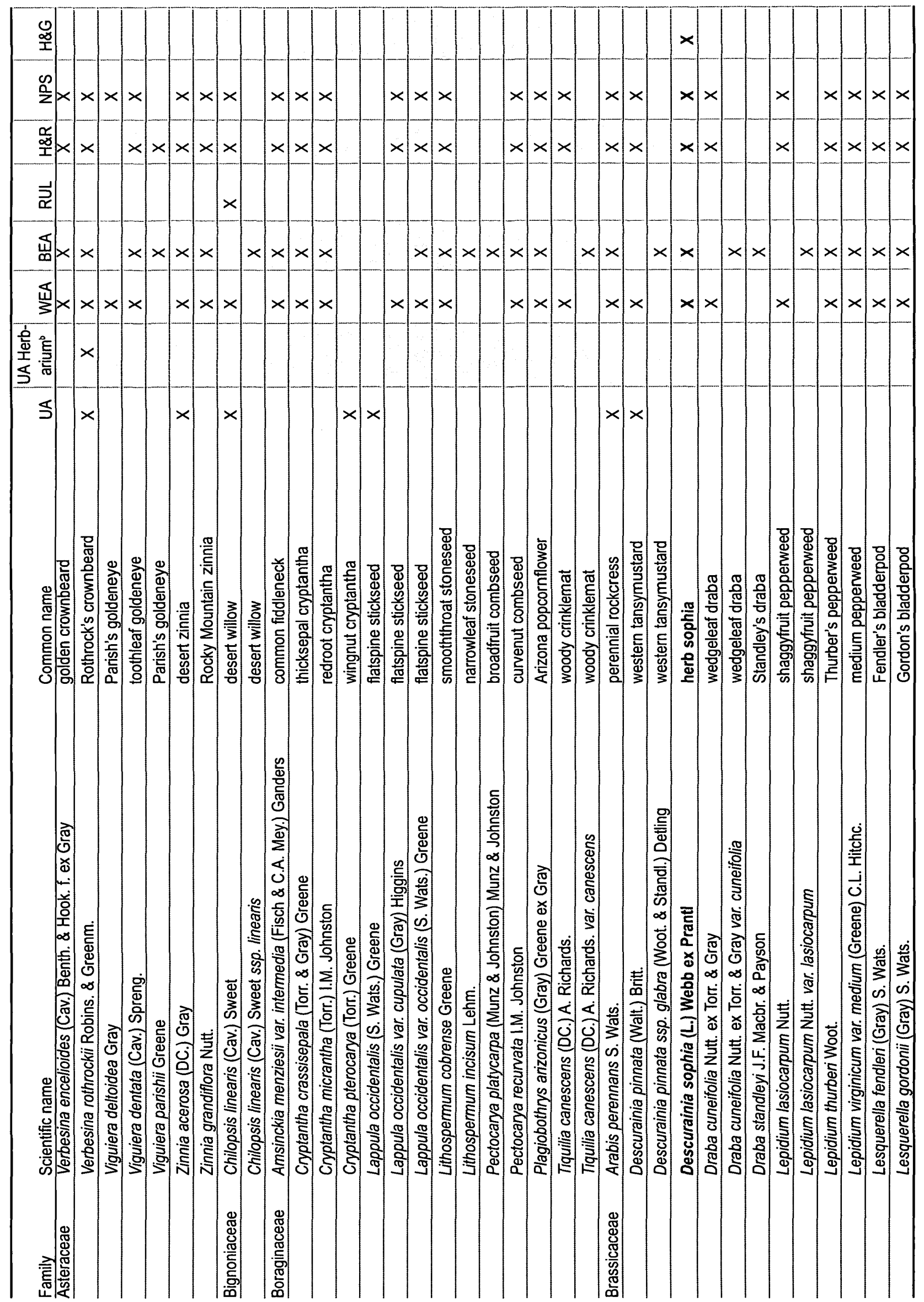




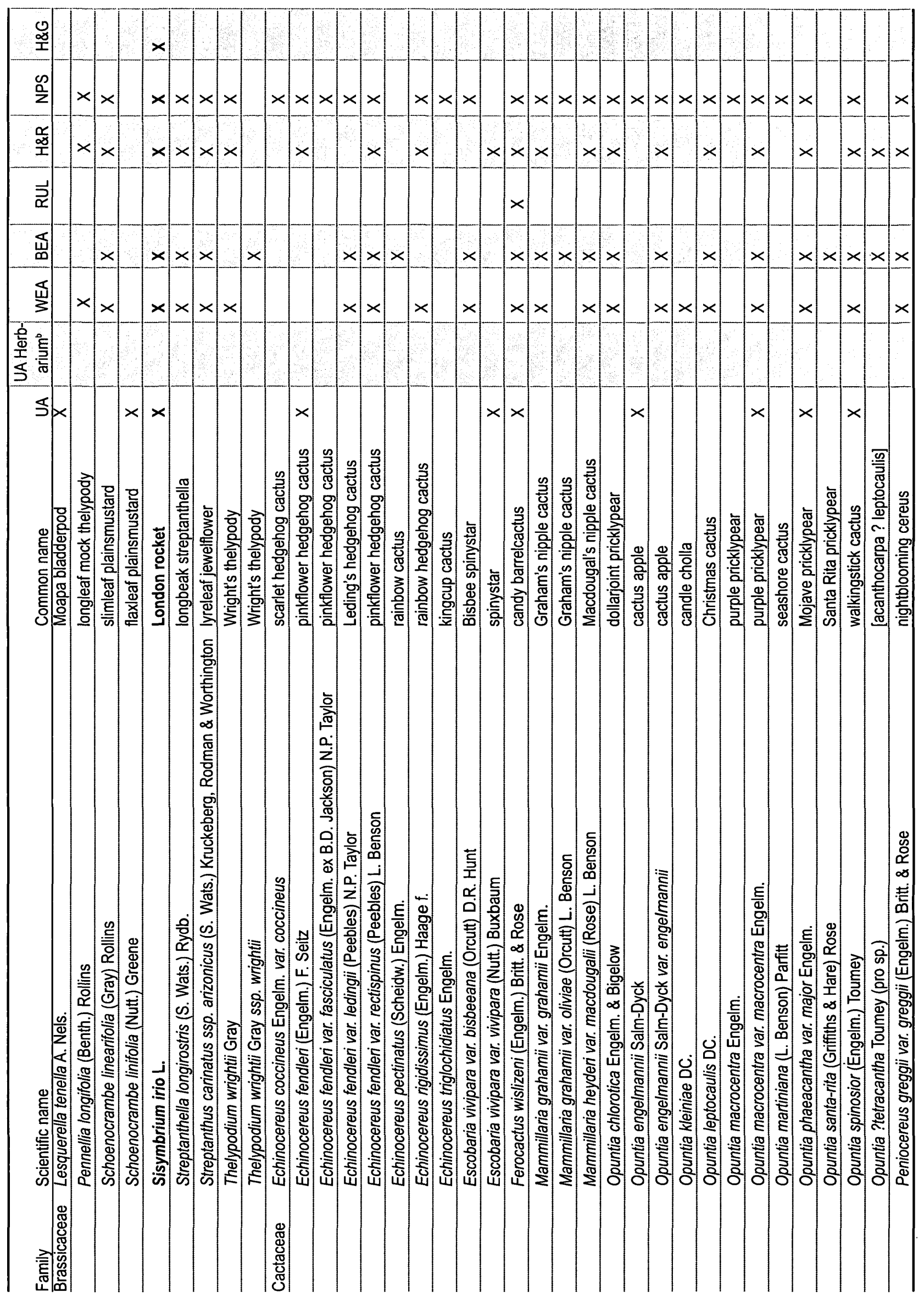




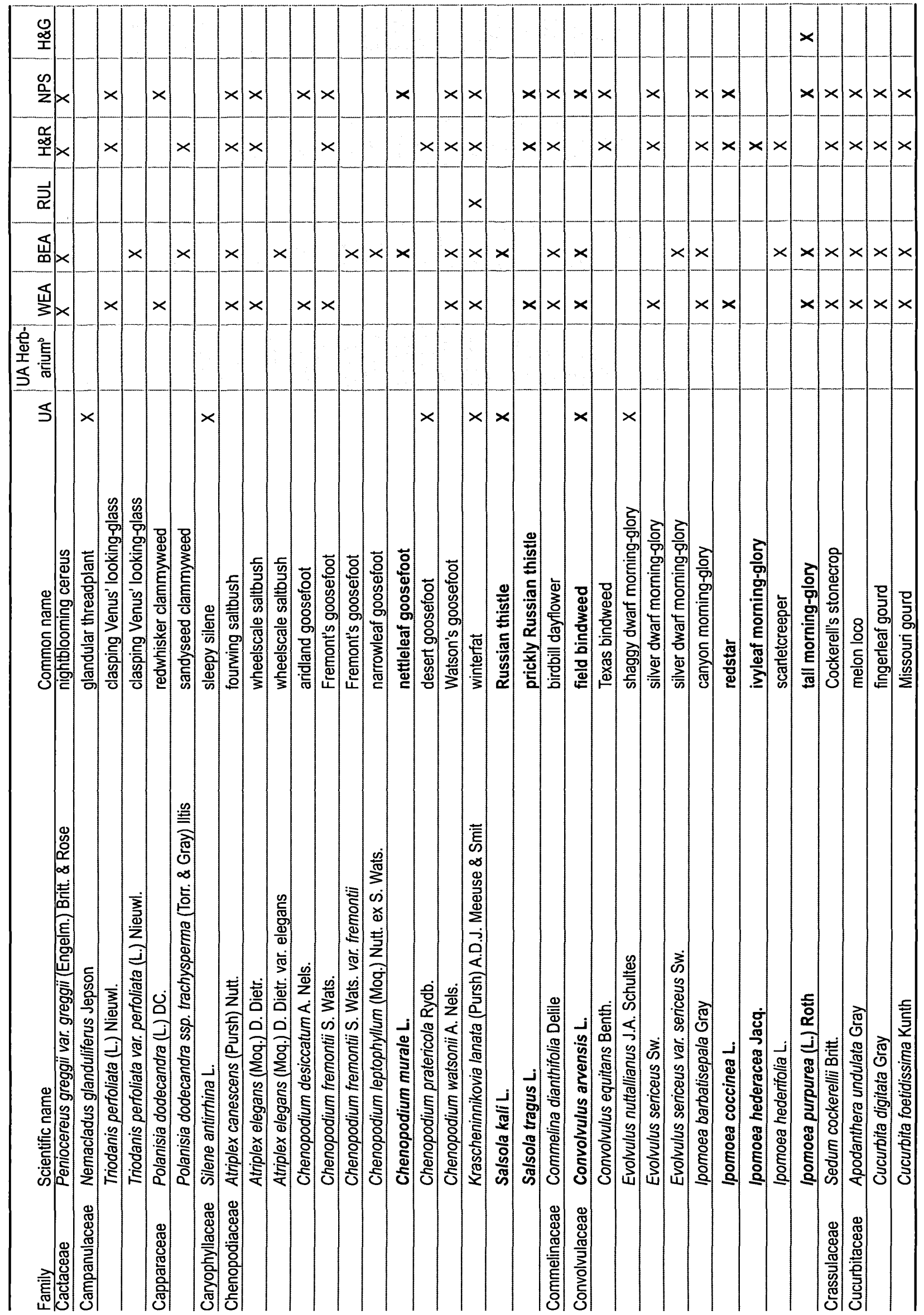




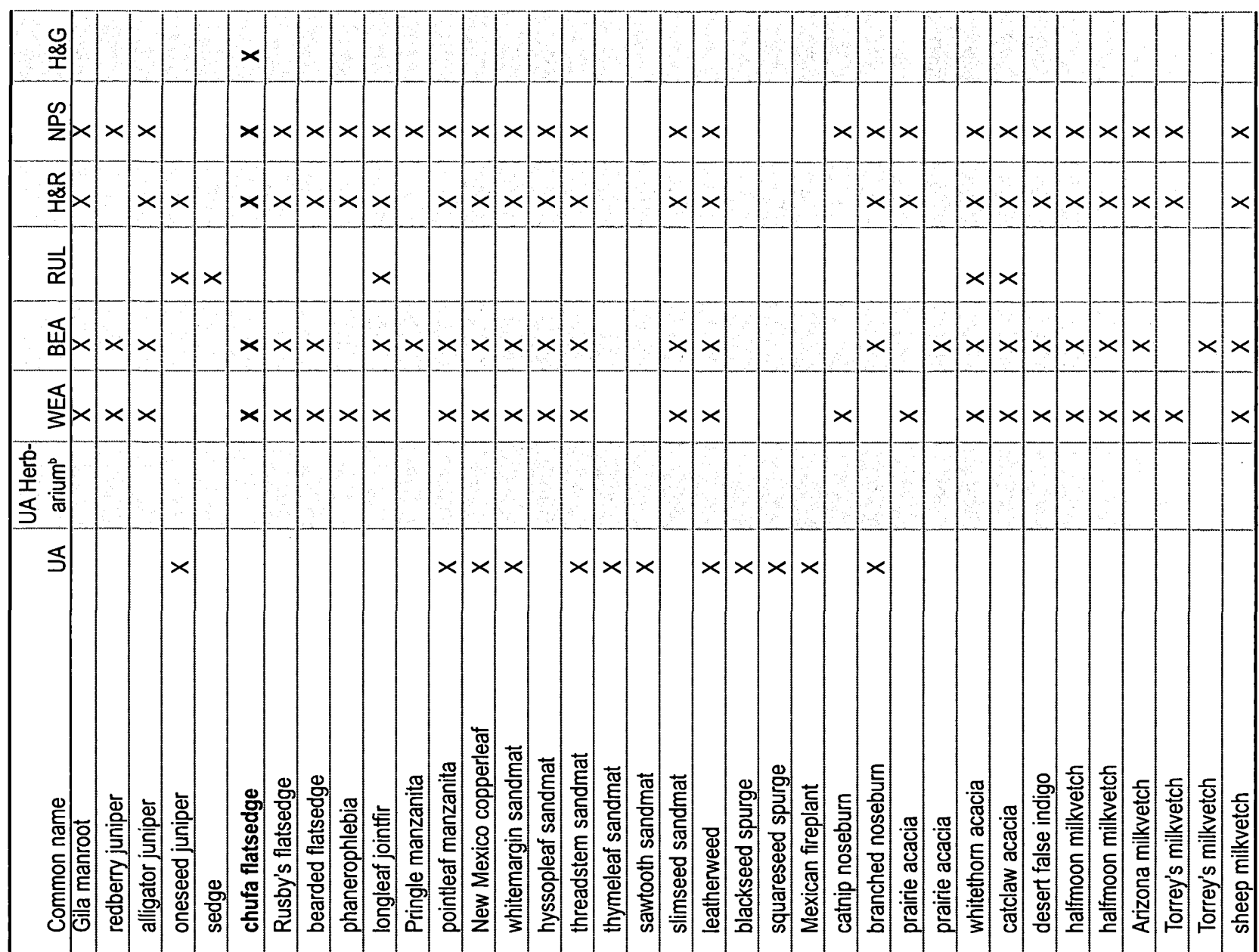

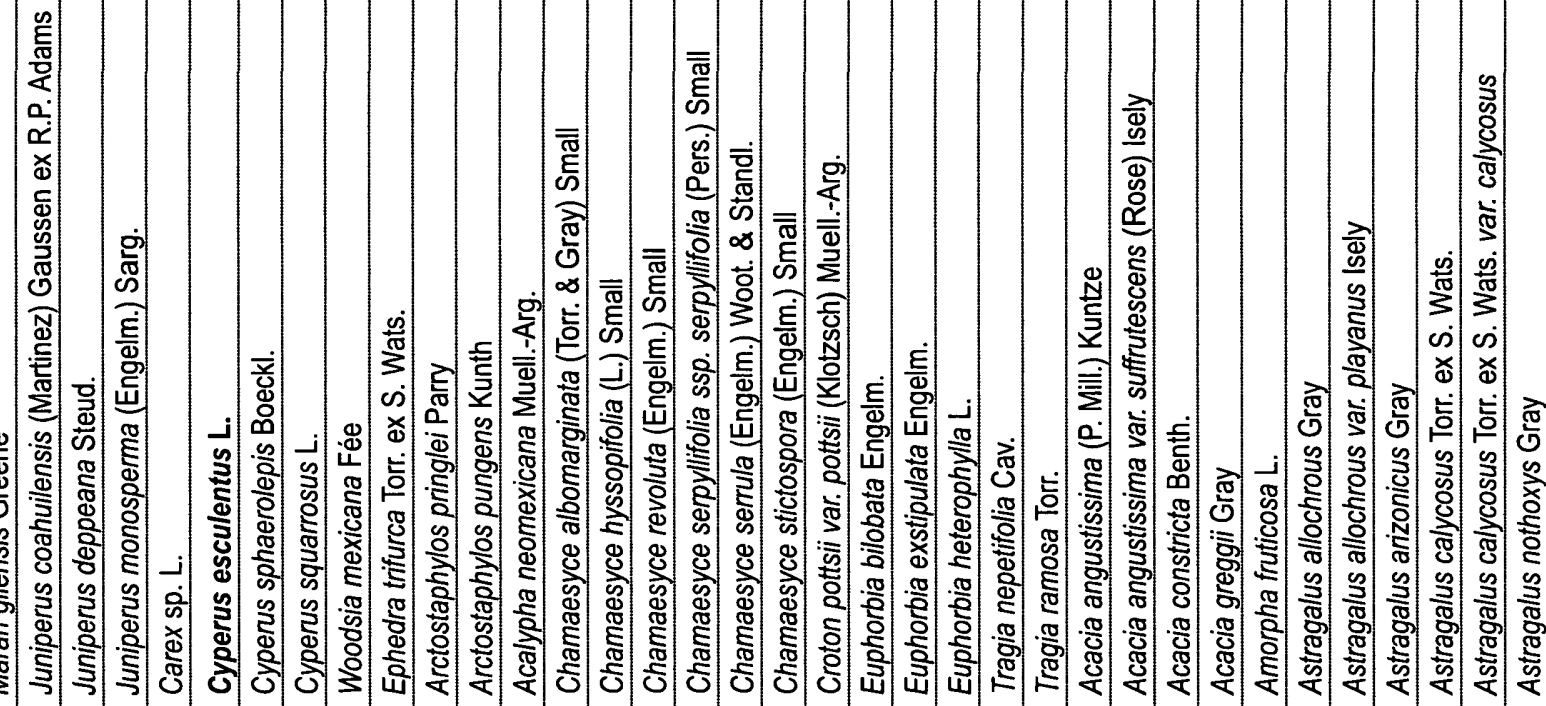

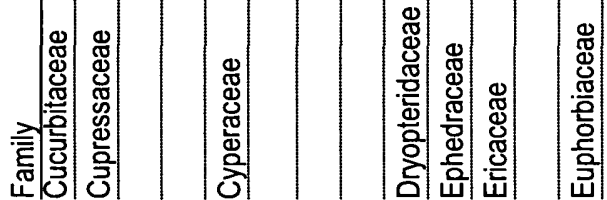




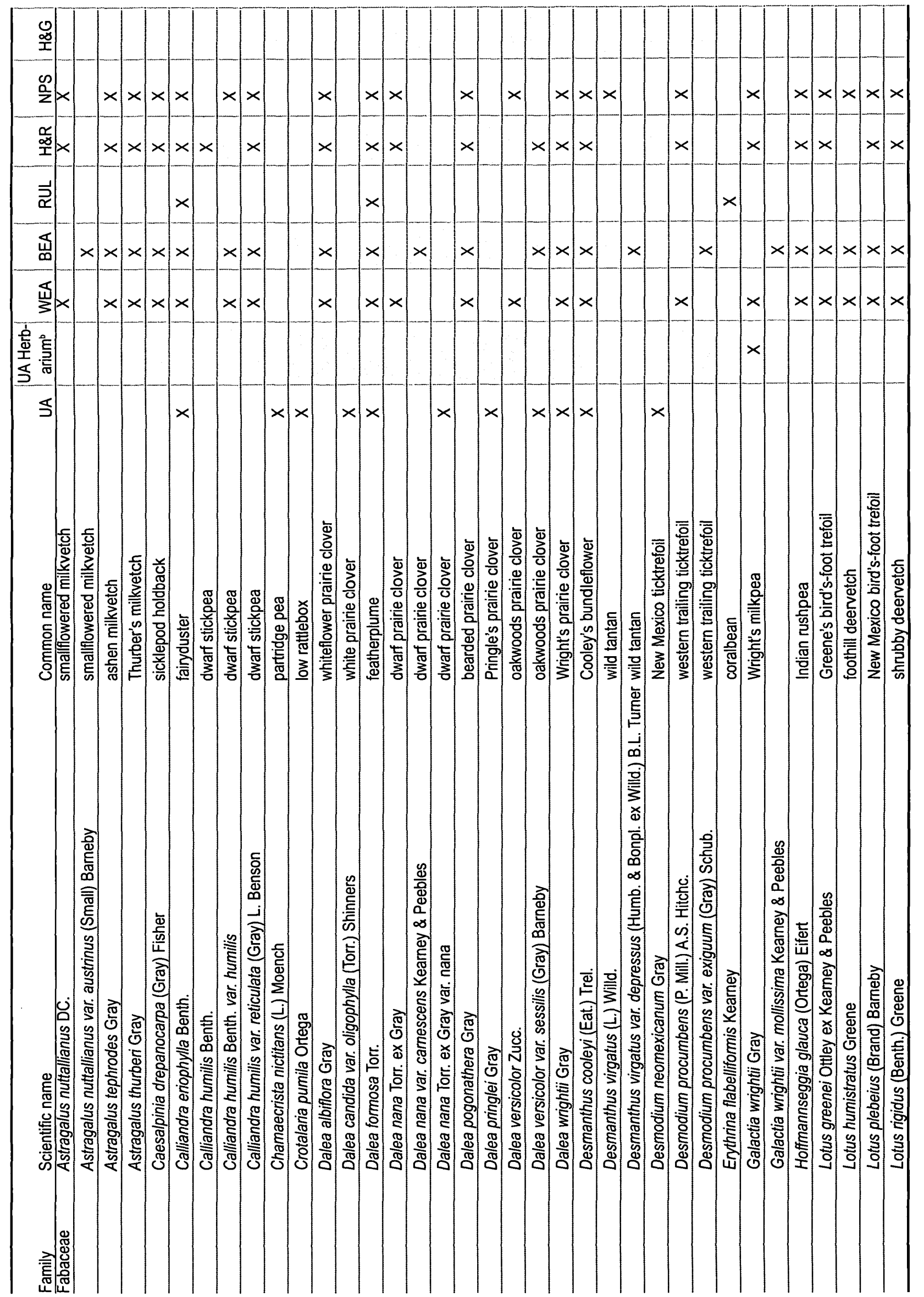




\begin{tabular}{|c|c|c|c|c|c|c|c|c|c|c|c|c|c|c|c|c|c|c|c|c|c|c|c|c|c|c|c|c|c|c|}
\hline $\begin{array}{l}0 \\
0 \\
1\end{array}$ & & & & & & & & & & & & & & & & & & & & & & & & & & & & & & $x$ \\
\hline$\frac{0}{2}$ & $x$ & $1 \times$ & 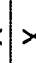 & $x$ & $x$ & & $x$ & $\times$ & & $x$ & $x$ & & $x$ & $\times$ & $\times$ & $\times$ & & $x$ & $x$ & $\times$ & $\times$ & $\times \mid>$ & $<$ & & $<\mid>$ & $x$ & $\mid x$ & $x$ & $x$ & $x$ \\
\hline 娄 & $x$ & $1 x$ & $1>$ & $x$ & $1 \times$ & & $x$ & $\times$ & $x$ & & $x$ & $\times$ & $\times$ & $x$ & & $\times$ & $x$ & $\times$ & $\times$ & $\times$ & $\times$ & $x>$ & $\mid>$ & $x \mid$ & $x \mid>$ & $1 \times$ & $1 \times$ & & $\times$ & $x$ \\
\hline$\vec{\sim}$ & & & & & & & $x$ & & & & $x$ & & & & & & & & & $\times$ & & & & & & $x$ & & & & \\
\hline
\end{tabular}

忽 $\times x \times x \times x \times x \times x \times x \times x \times x \times x \times x \times x \times x \times x$

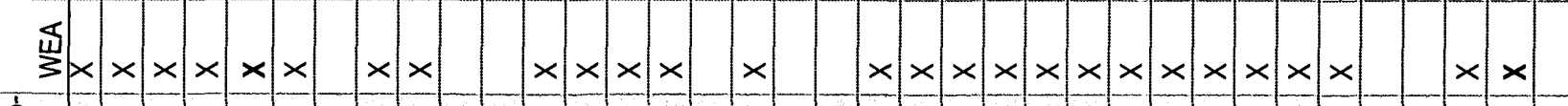
旁

$5 \times \times \times \times \times$

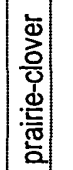

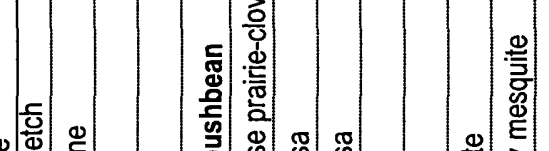

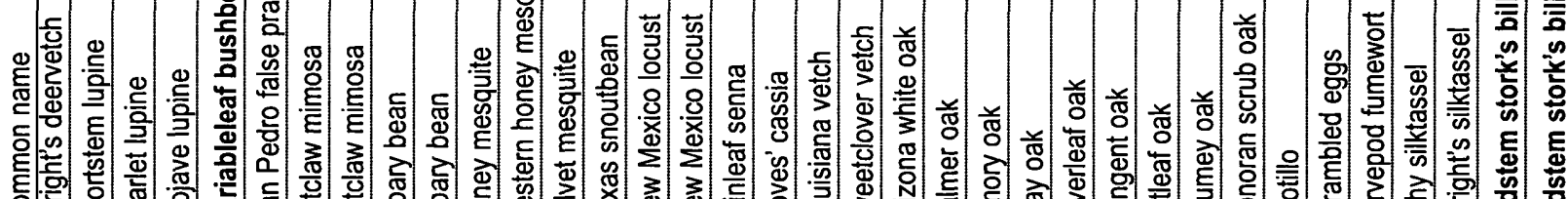

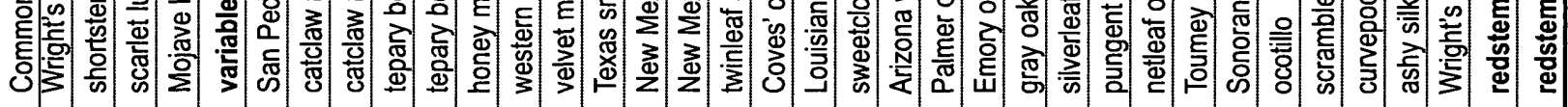

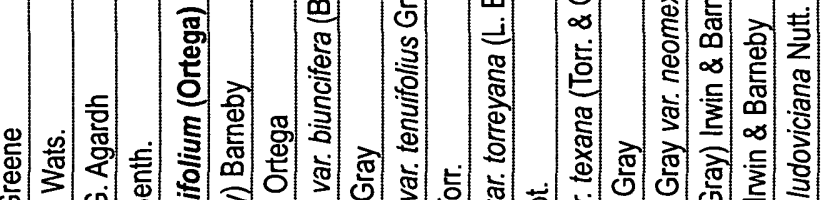

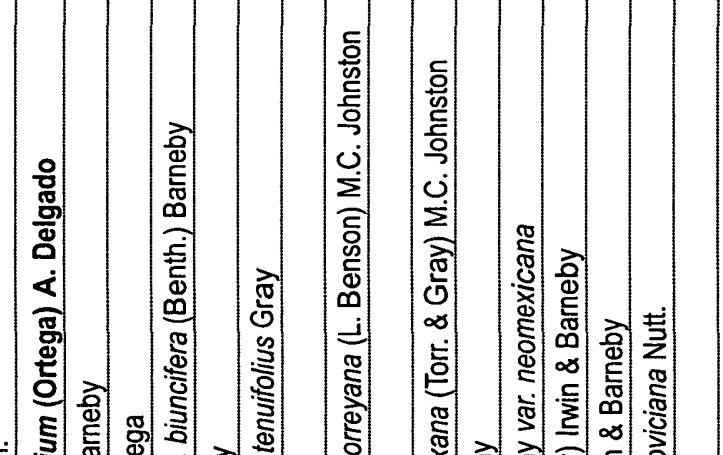

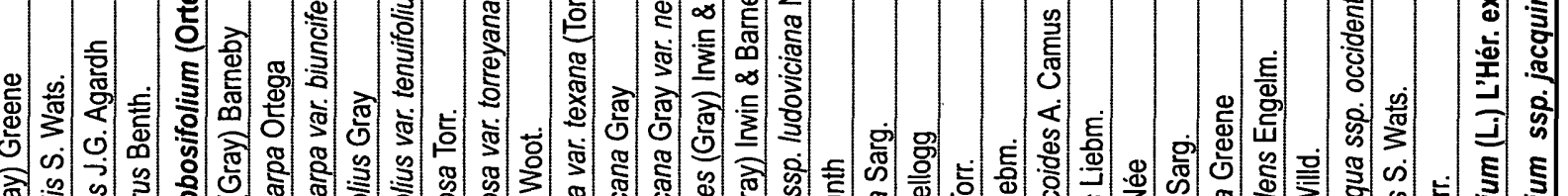

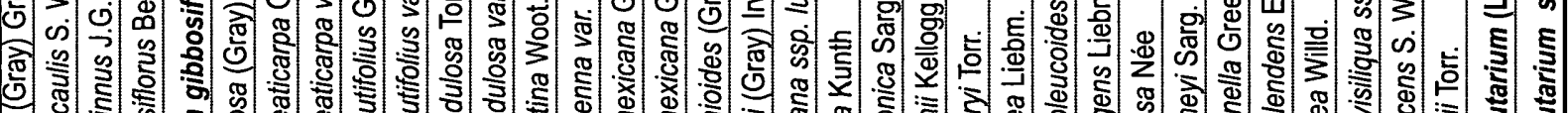

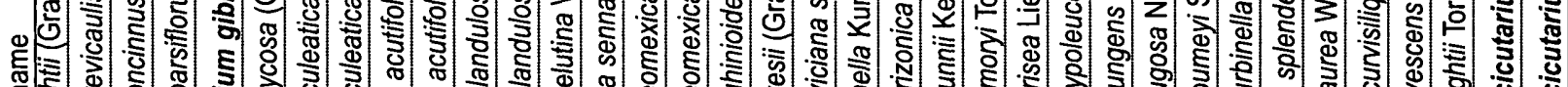
है:

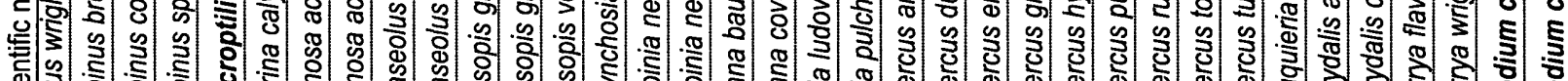

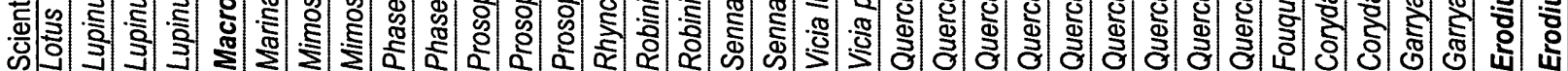

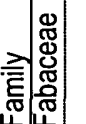

$\mid$

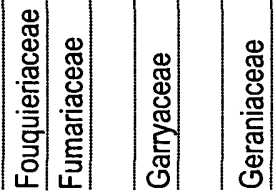




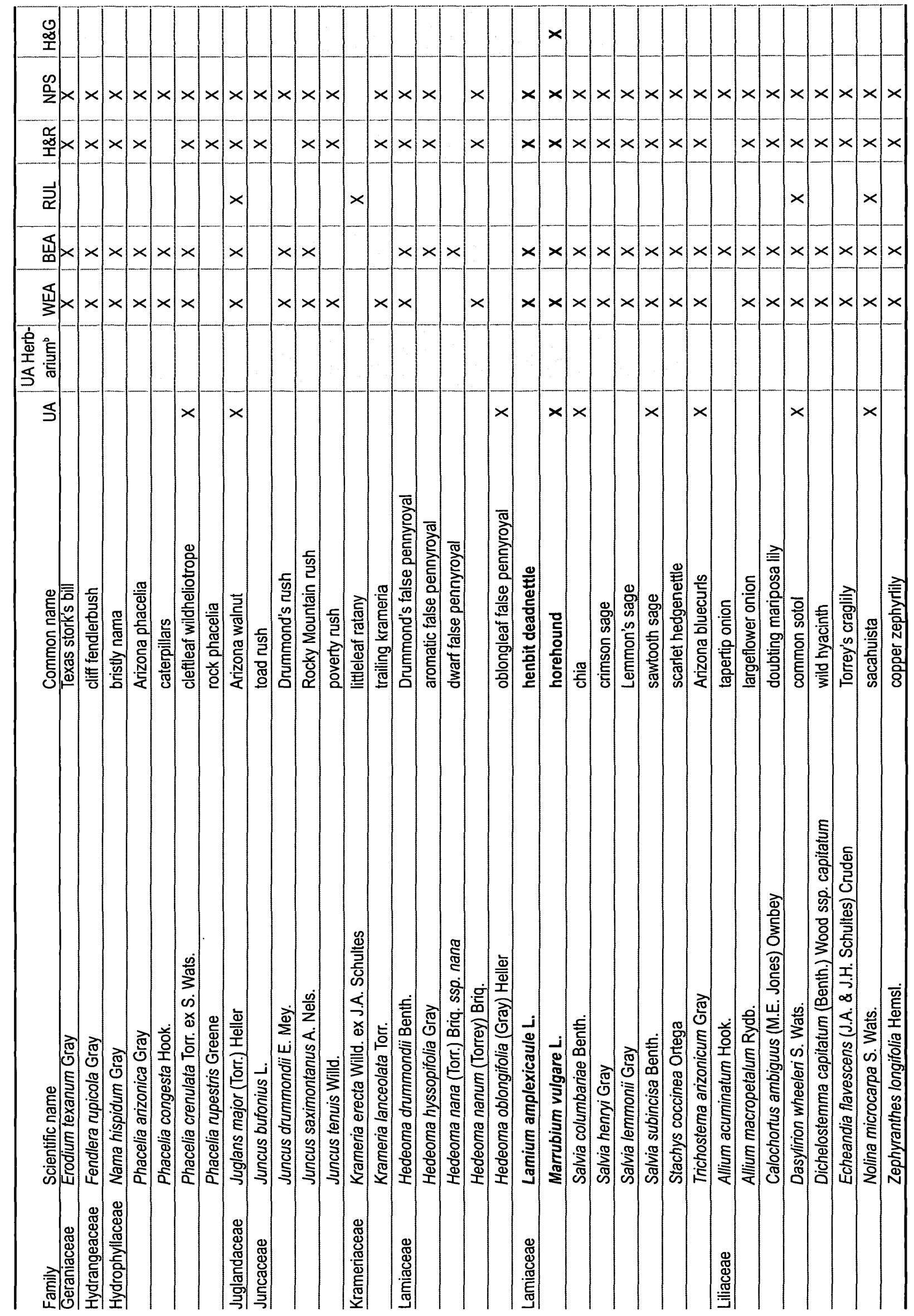




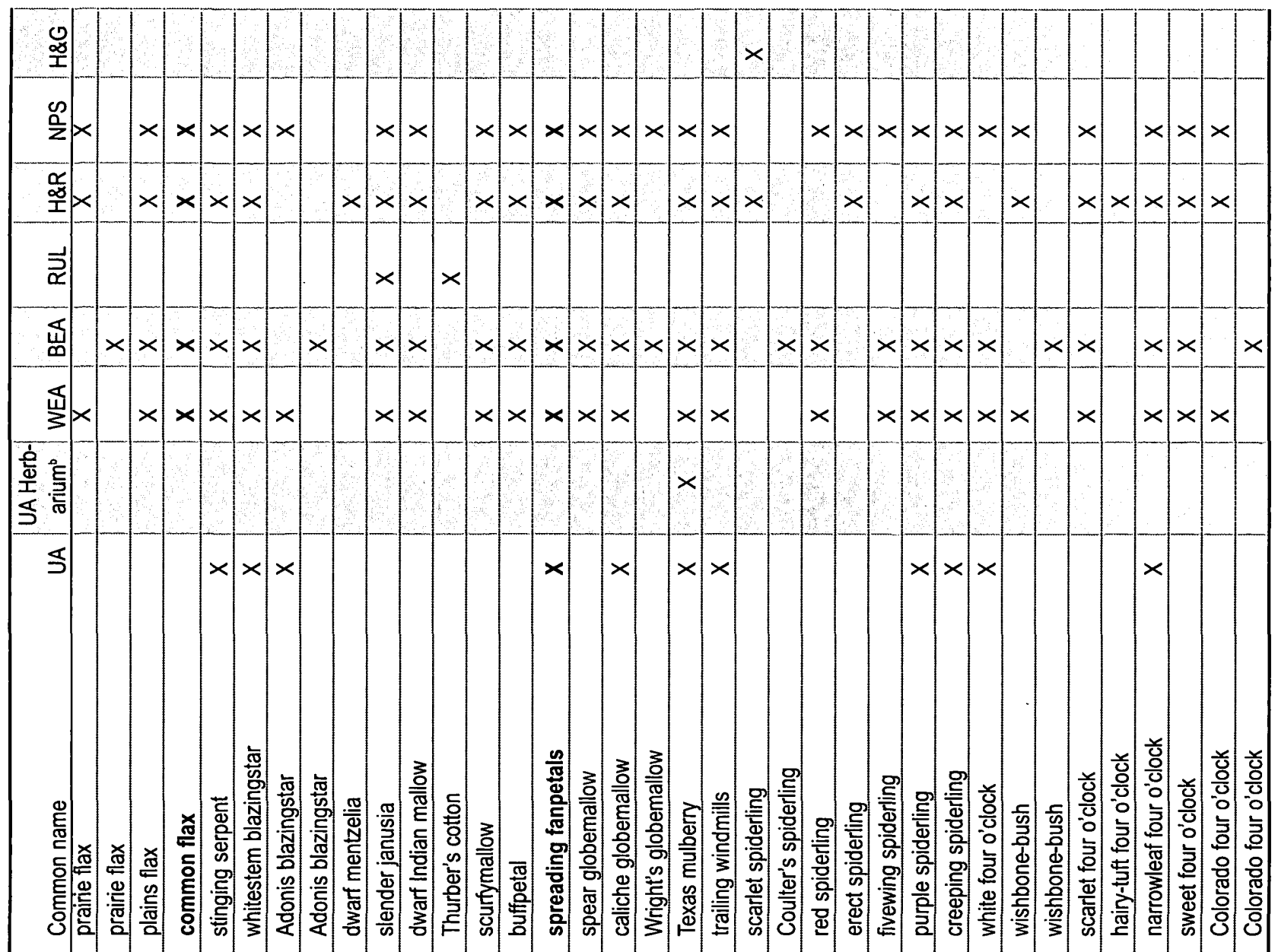

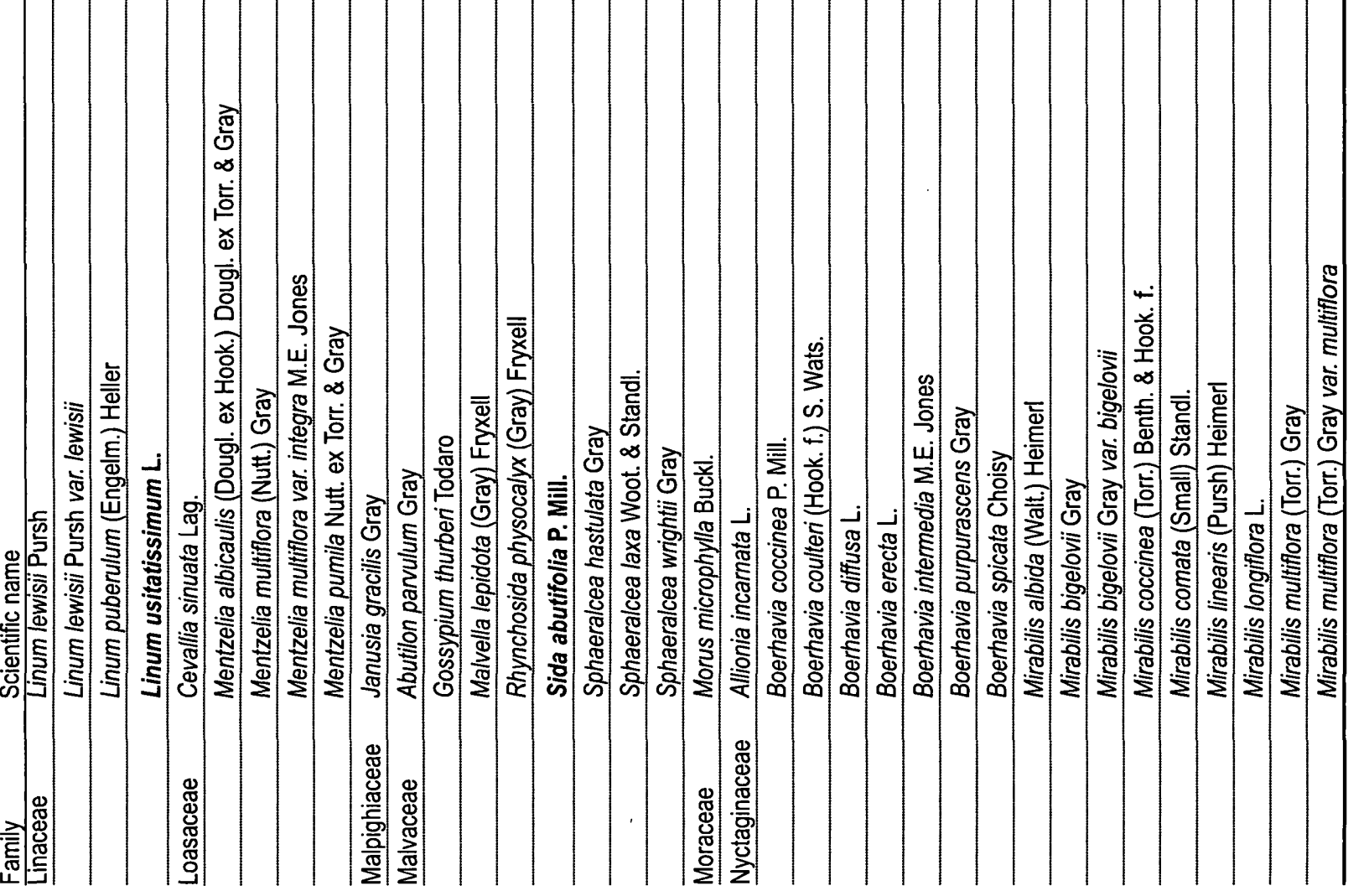




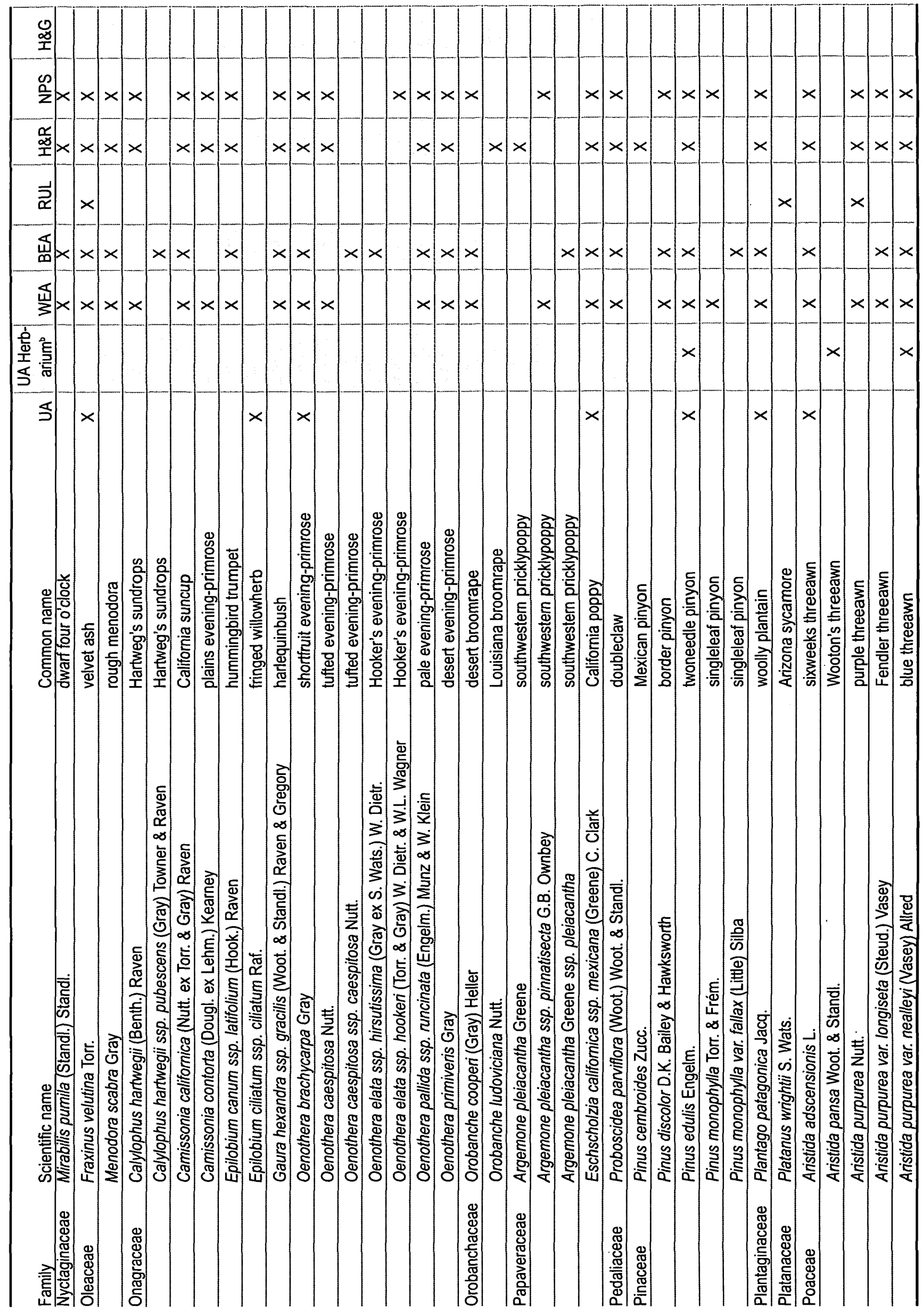




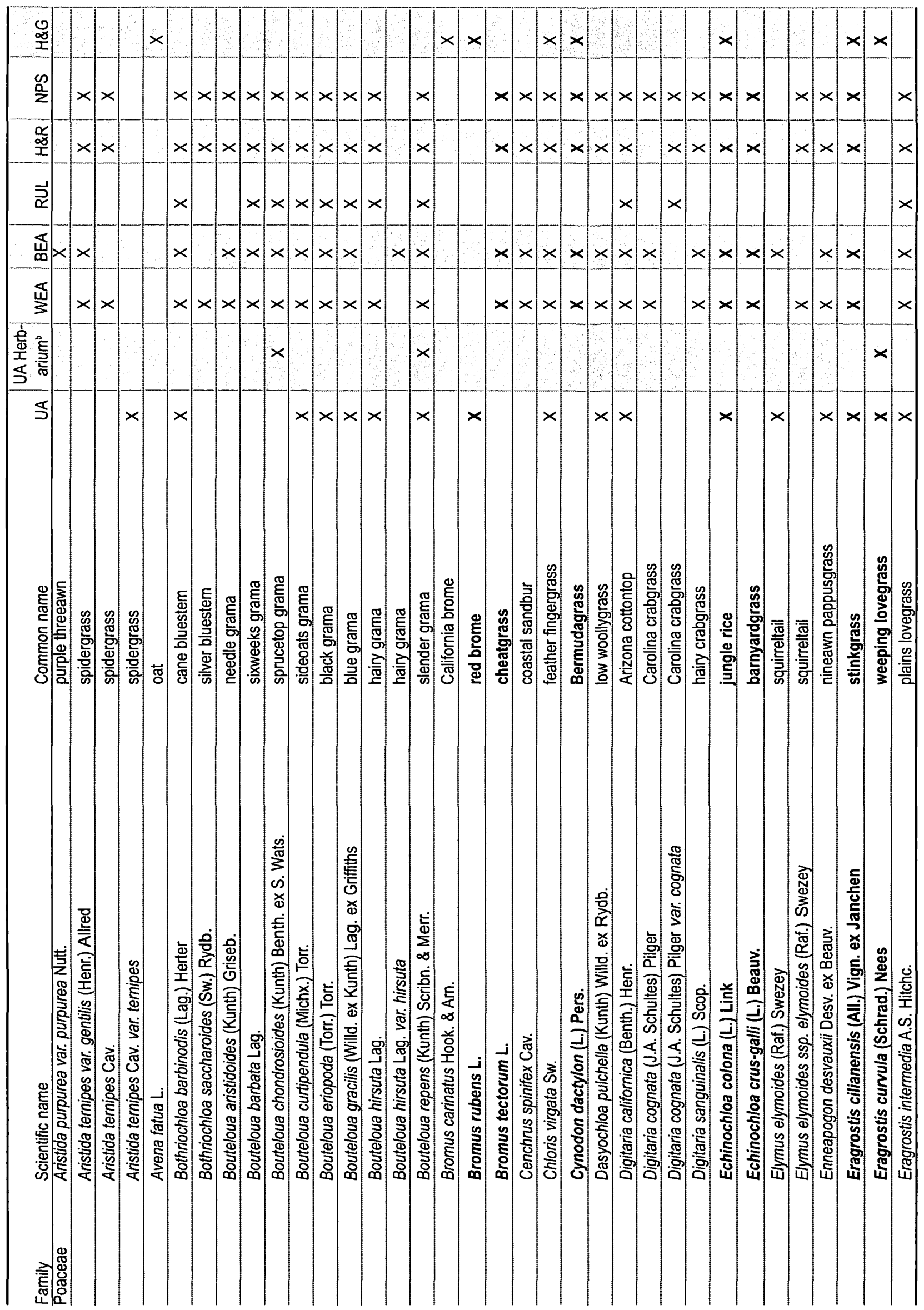




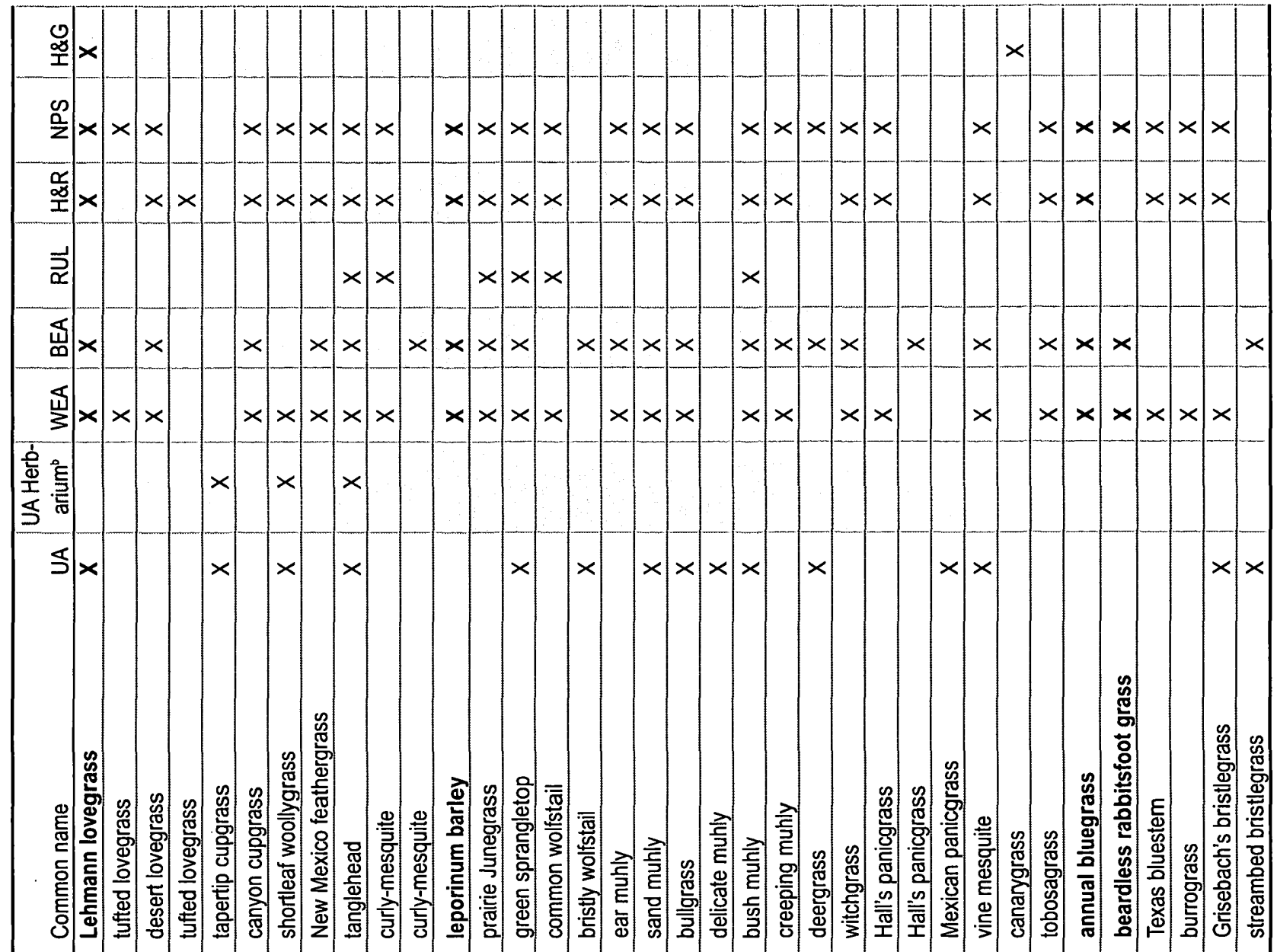

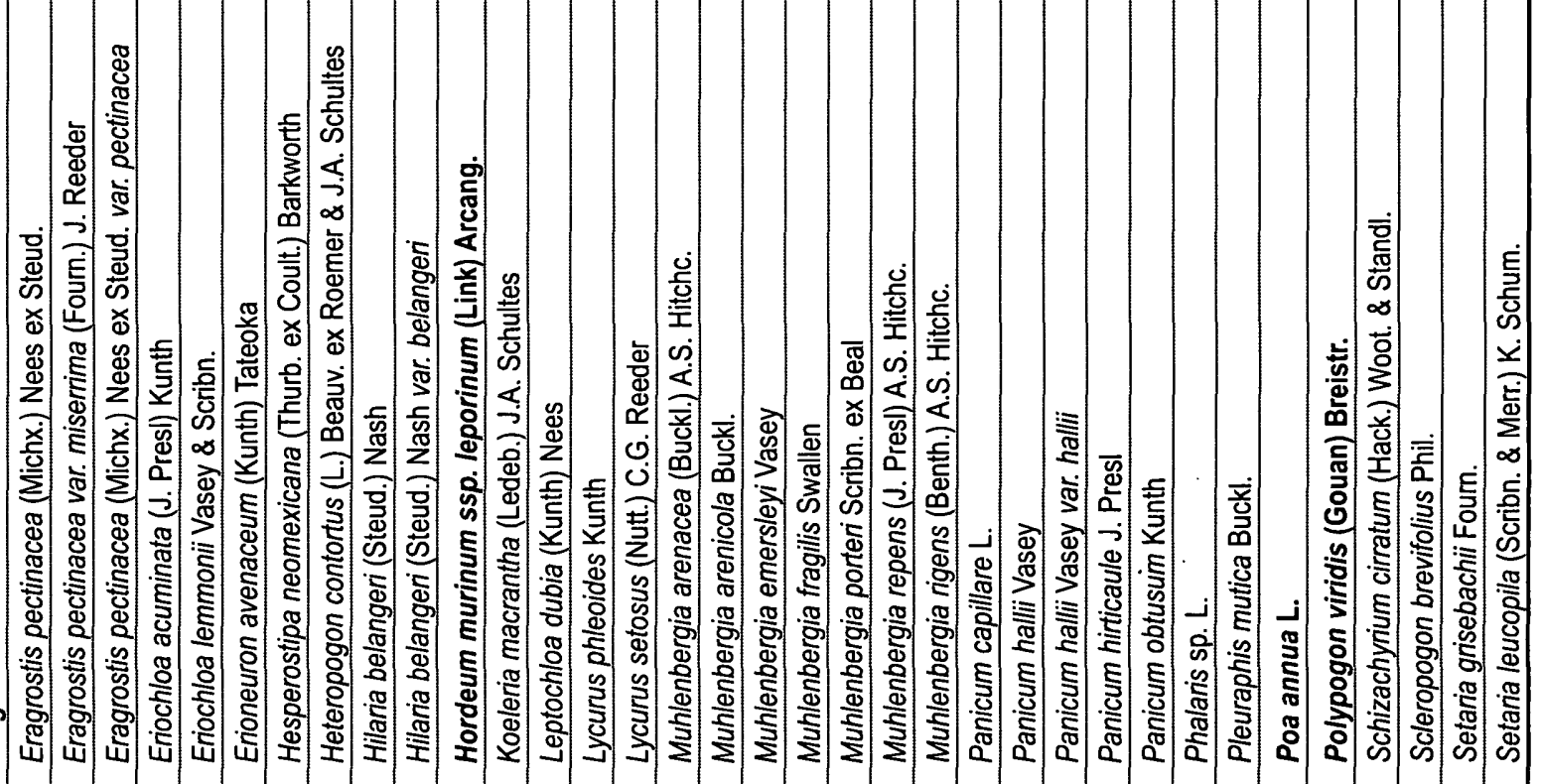




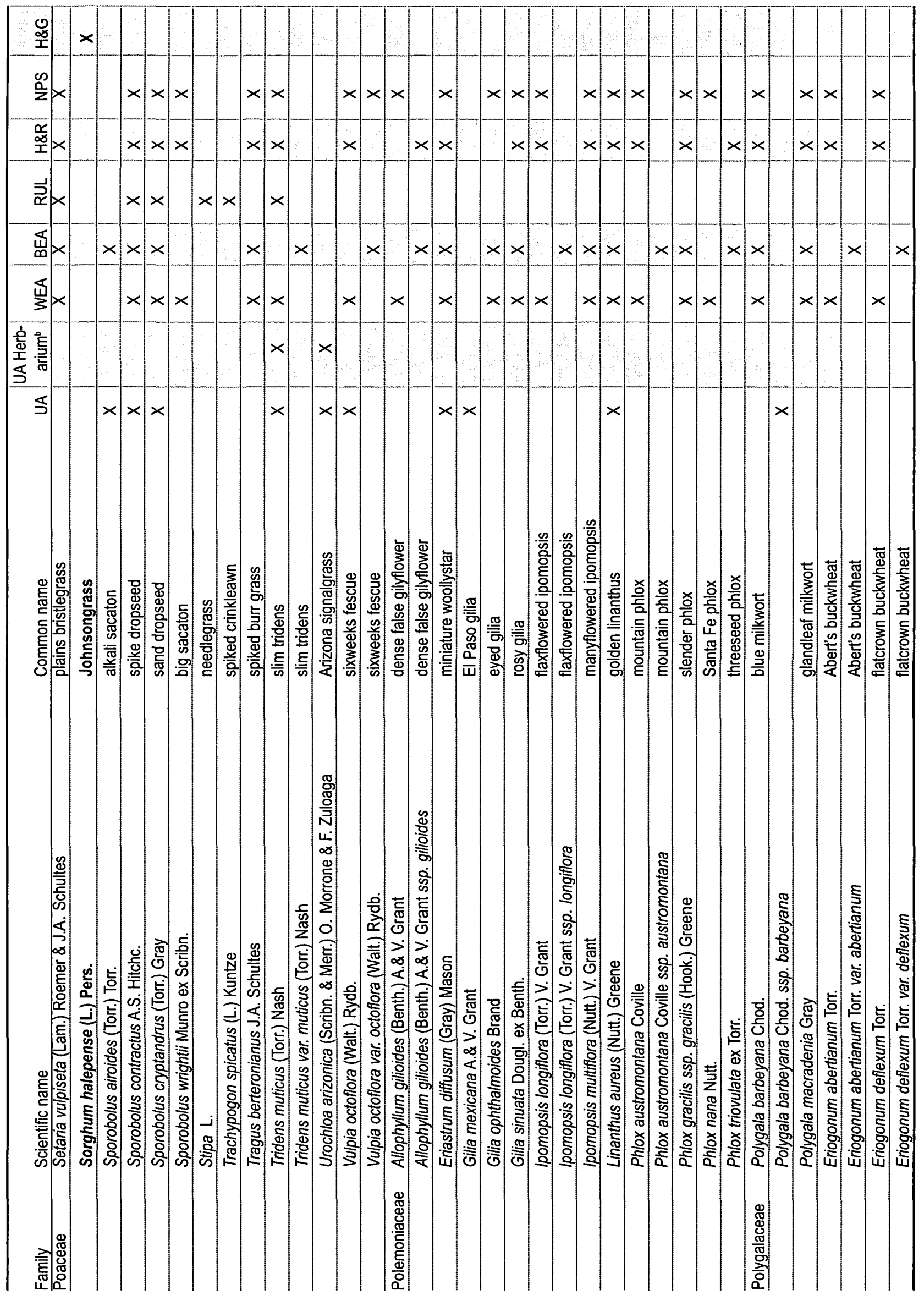




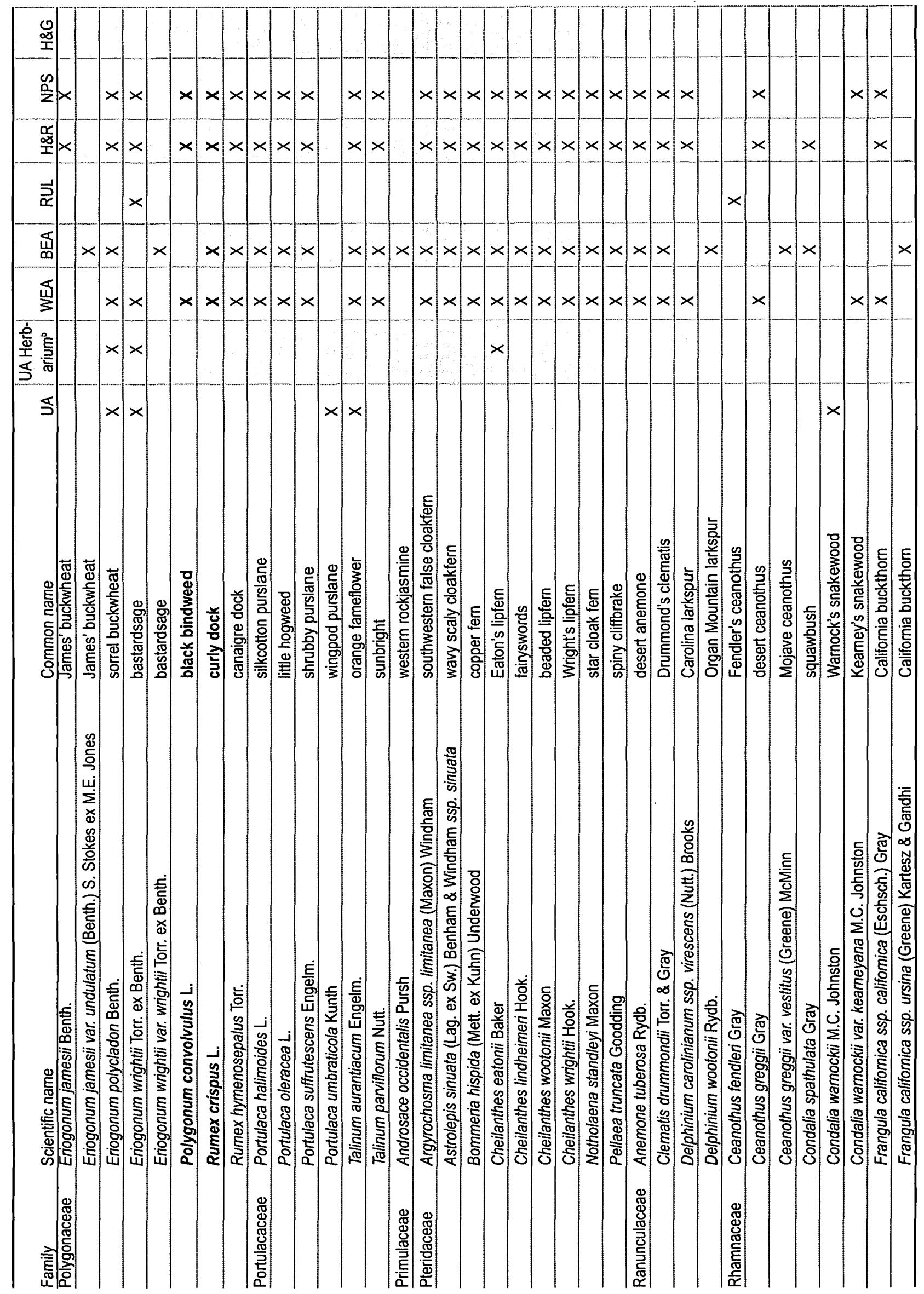




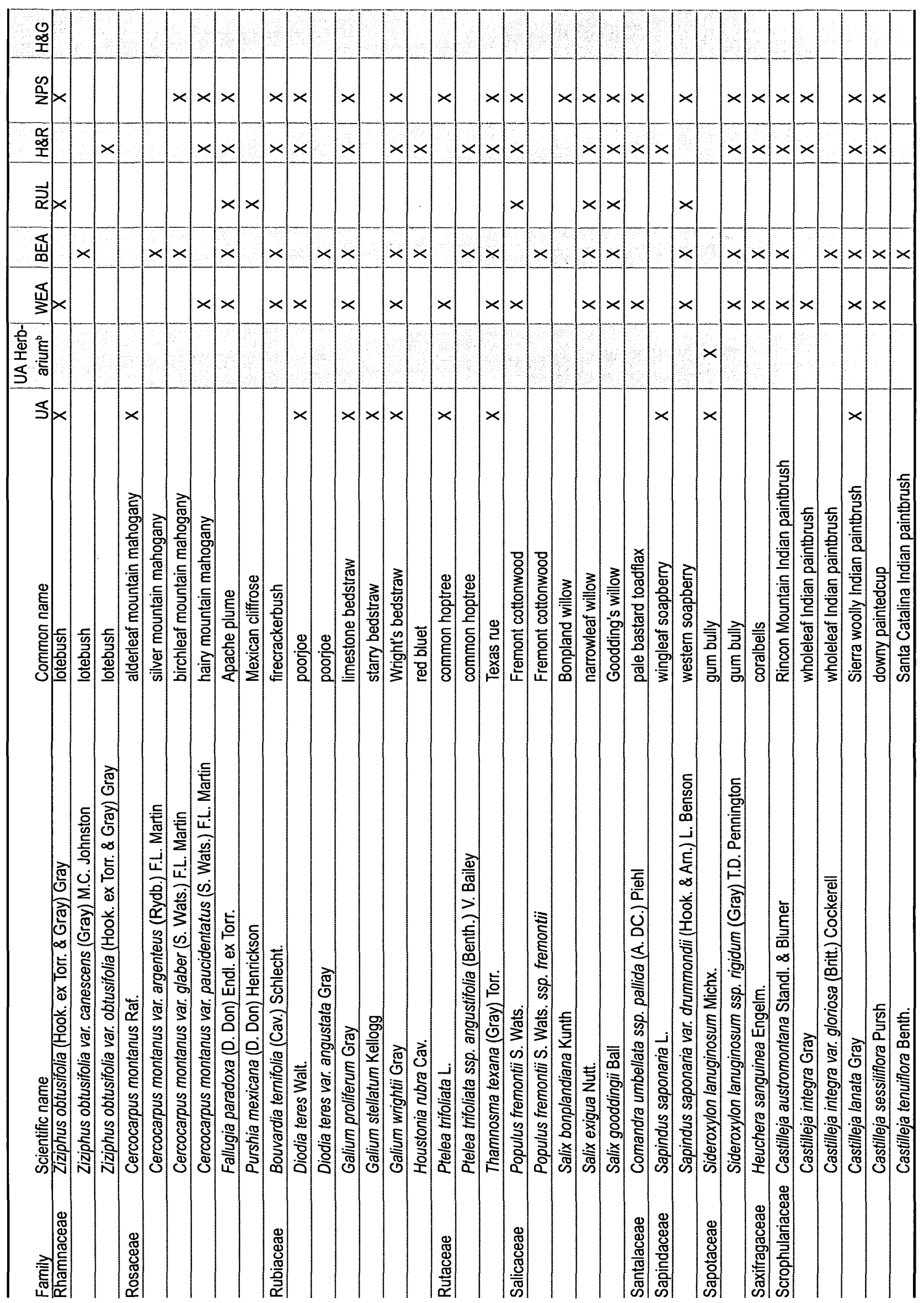




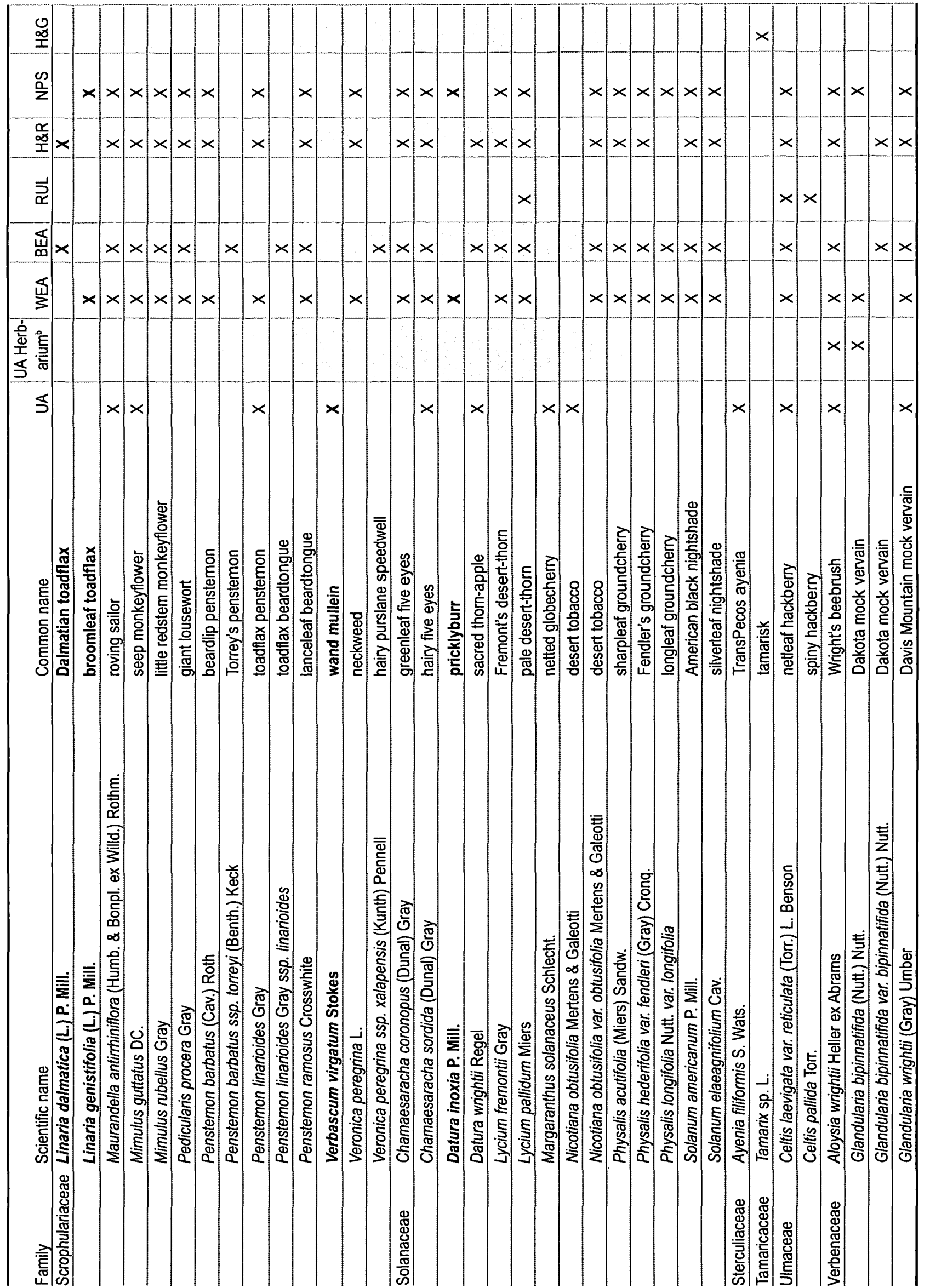




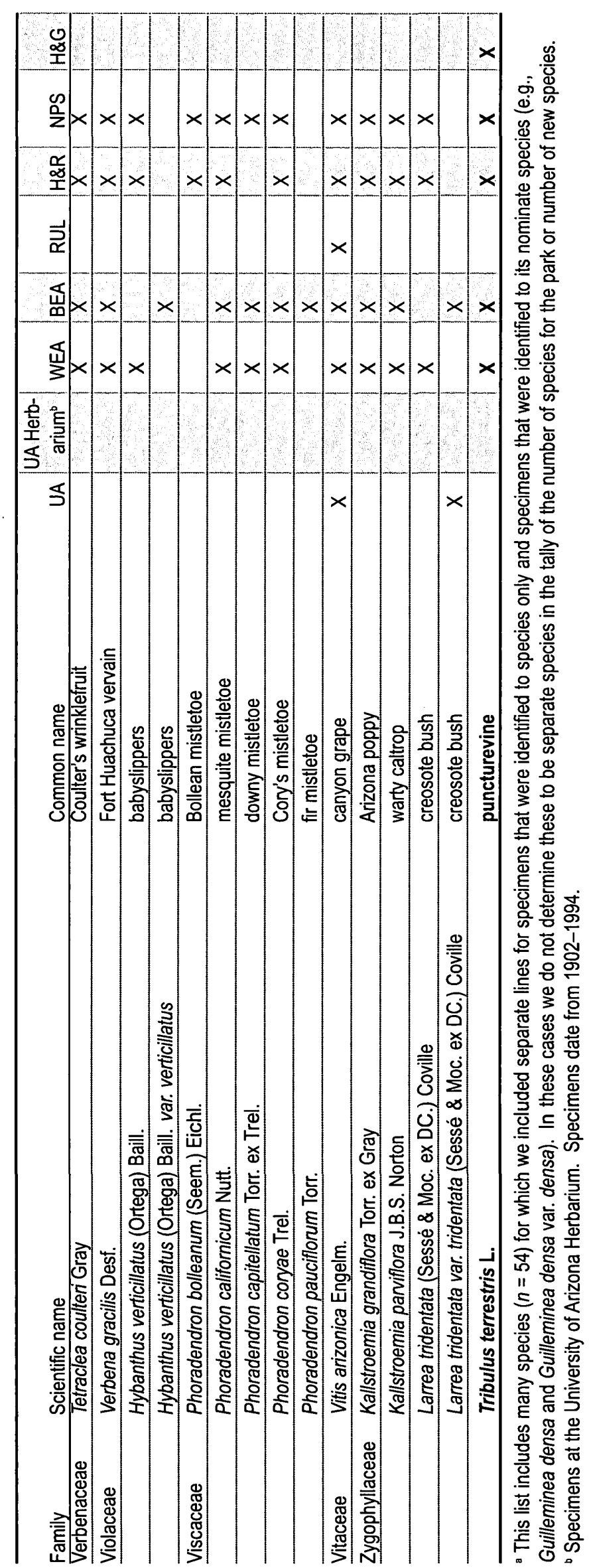


Appendix B. Amphibians and reptiles observed or documented at Fort Bowie NHS by University of Arizona (UA) personnel, Swann et al. (2001; Swann), Lowe and Johnson (1976; L\&J), and from voucher specimens reported in Appendix E (AE). "Possible" species have not been observed or documented in the park, but may occur based on habitat and range (reported in Swann et al. [2001]).

\begin{tabular}{|c|c|c|c|c|c|c|c|c|}
\hline \multirow[b]{2}{*}{ Order } & \multirow[b]{2}{*}{ Family } & \multirow[b]{2}{*}{ Scientific name } & \multirow[b]{2}{*}{ Common name } & \multicolumn{4}{|c|}{ Observed or documented } & \multirow[b]{2}{*}{ Possible } \\
\hline & & & & UA & Swann & L\&J & $\mathrm{AE}$ & \\
\hline Caudata & Ambystomatidae & Ambystoma tigrinum mavortium & barred tiger salamander & & & & & $\mathrm{X}$ \\
\hline \multirow[t]{12}{*}{ Anura } & Pelobatidae & Scaphiopus couchii & Couch's spadefoot & & $x$ & $x$ & & \\
\hline & & Spea bombifrons & plains spadefoot & & & $x$ & & $x$ \\
\hline & & Spea multiplicata & Mexican spadefoot & & $x$ & $x$ & & \\
\hline & Bufonidae & Bufo punctatus & red-spotted toad & & $x$ & $x$ & & \\
\hline & & Bufo cognatus & Great Plains toad & & $x$ & $x$ & & \\
\hline & & Bufo alvarius & Sonoran desert toad & & & & & $x$ \\
\hline & & Bufo woodhousii & Woodhouse's toad & & & & & $x$ \\
\hline & & Bufo debilis & Green toad & & & $x$ & & \\
\hline & Hylidae & Hyla arenicolor & canyon treefrog & & $\mathrm{x}$ & $x$ & & \\
\hline & Ranidae & Rana catesbeiana & American bullfrog & & & & & $x$ \\
\hline & & Rana chiricahuensis ${ }^{a}$ & Chiricahua leopard frog & & $x$ & $x$ & & \\
\hline & & Rana blairi & plains leopard frog & & & & & $x$ \\
\hline \multirow[t]{4}{*}{ Testudines } & Kinosternidae & Kinosternon flavescens & yellow mud turtle & & & & & $x$ \\
\hline & & Kinosternon sonoriense & Sonoran mud turtle & & & & & $x$ \\
\hline & Emydidae & Terrapene ornata & western box turtle & & & $x$ & & $x$ \\
\hline & Testudinidae & Gopherus agassizii sonoran & Sonoran desert tortoise & & & & & $x$ \\
\hline \multirow[t]{24}{*}{ Squamata } & Eublepharidae & Coleonyx variegatus & western banded gecko & & $x$ & $x$ & & \\
\hline & Crotaphytidae & Crotaphytus collaris & eastern collared lizard & & $x$ & $x$ & $x$ & \\
\hline & & Gambelia wislizenii & long-nosed leopard lizard & & & & & $x$ \\
\hline & Phrynosomatidae & Holbrookia maculata & lesser earless lizard & $x$ & & & & \\
\hline & & Cophosaurus texanus & greater earless lizard & $x$ & $x$ & $x$ & & \\
\hline & & Callisaurus draconoides & zebra-tailed lizard & & & & & $x$ \\
\hline & & Sceloporus clarkii & Clark's spiny lizard & & $x$ & & $x$ & \\
\hline & & Sceloporus virgatus & striped plateau lizard & $x$ & & & & \\
\hline & & Sceloporus slevini & Slevin's bunchgrass lizard & & & & & $x$ \\
\hline & & Sceloporus jarrovii & mountain spiny lizard & & & & & $\mathrm{x}$ \\
\hline & & Sceloporus magister & desert spiny lizard & & & & & $x$ \\
\hline & & Sceloporus undulatus & eastern fence lizard & & & & & $x$ \\
\hline & & Urosaurus ornatus & ornate tree lizard & $x$ & $x$ & $x$ & $x$ & \\
\hline & & Uta stansburiana & common side-blotched lizard & & & & & $x$ \\
\hline & & Phrynosoma cornutum & Texas horned lizard & & $x$ & $x$ & & \\
\hline & & Phrynosoma douglasii & pygmy short-horned lizard & & $x$ & $x$ & & \\
\hline & & Phrynosoma modestum & round-tailed horned lizard & & $x$ & $x$ & & \\
\hline & & Phrynosoma solare & regal horned lizard & & & & & $x$ \\
\hline & Scincidae & Eumeces obsoletus & Great Plains skink & & $x$ & $x$ & & \\
\hline & Teiidae & Cnemidophorus uniparens & desert grassland whiptail & & $x$ & $x$ & & \\
\hline & & Cnemidophorus exsanguis & Chihuahuan spotted whiptail & & $x$ & & $x$ & \\
\hline & & Cnemidophorus sonorae & Sonoran spotted whiptail & & $x$ & $x$ & & \\
\hline & & Cnemidophorus tigris & western whiptail (tiger whiptail) & & $x$ & $x$ & & \\
\hline & & Cnemidophorus burti & canyon spotted whiptail & & & & & $\mathrm{x}$ \\
\hline
\end{tabular}




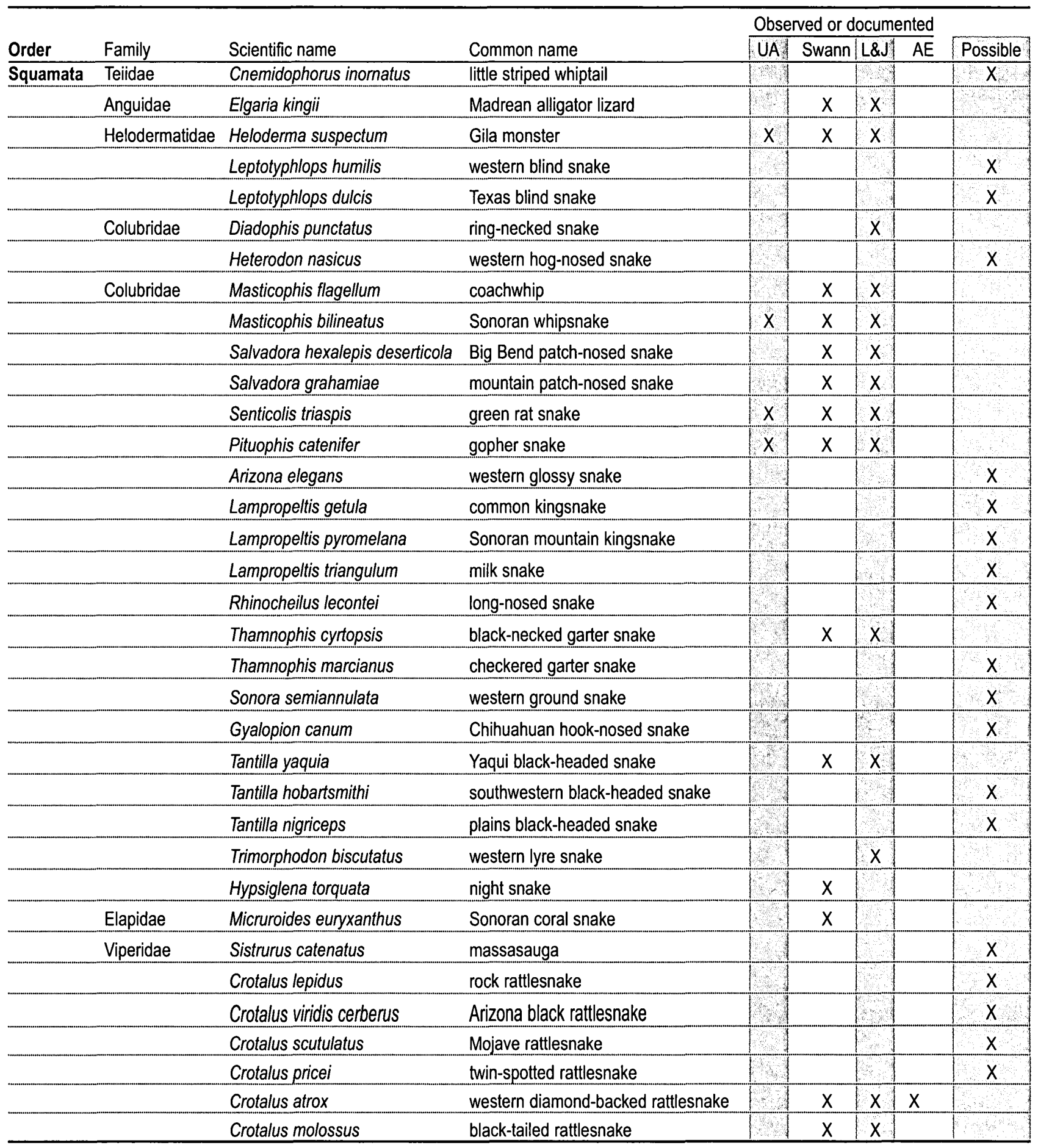

"Now extirpated from the park. Listed as "Threatened" under the Endangered Species Act, "Sensitive" by the U.S.D.A. Forest Service, and "Wildlife of Special Concern" by the Arizona Game and Fish Department (HDMS 2004).

" "Species of Concern" by U.S. Fish and Wildlife Service, and "Wildlife of Special Concern" by the Arizona Game and Fish Department (HDMS 2004). 


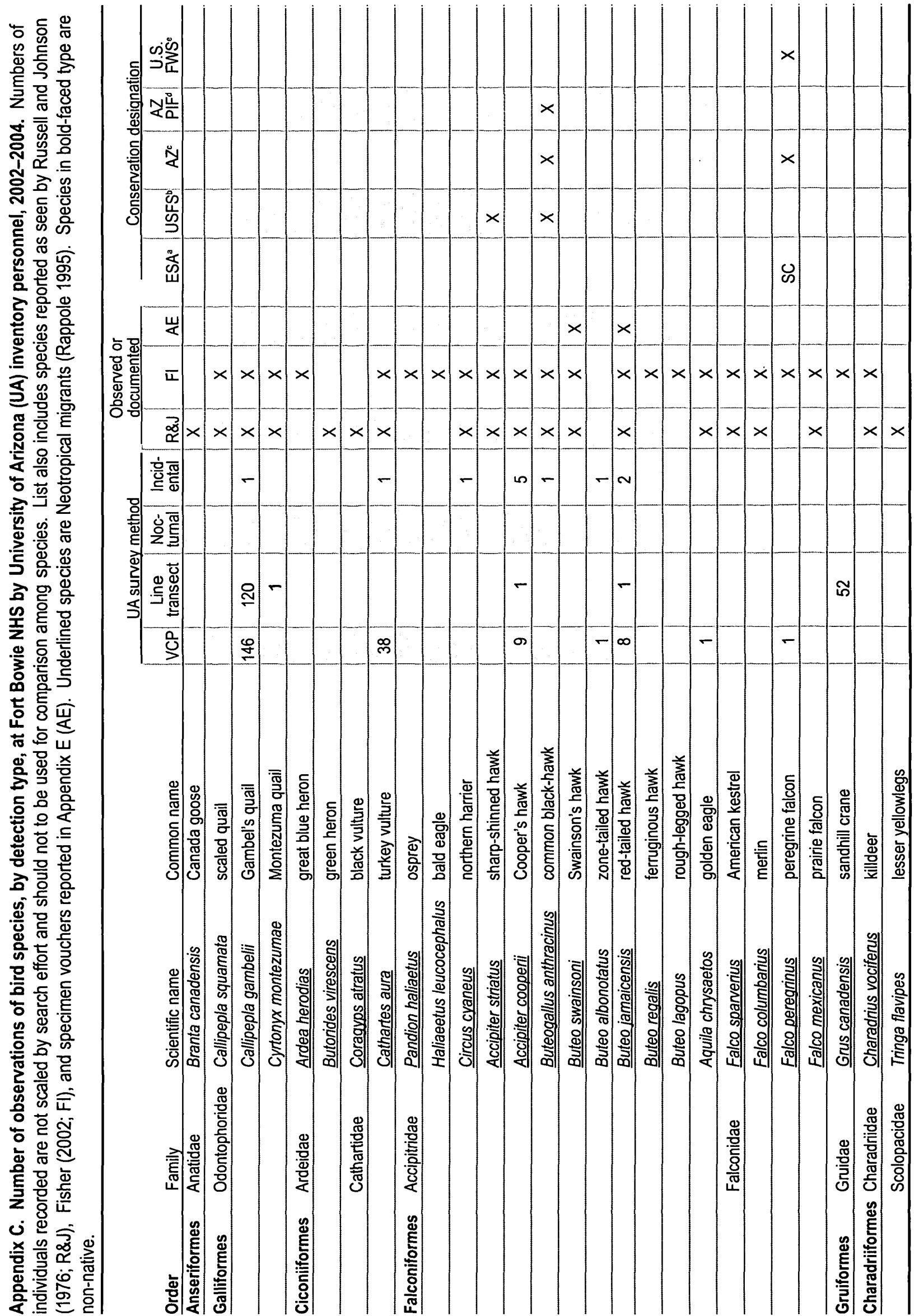




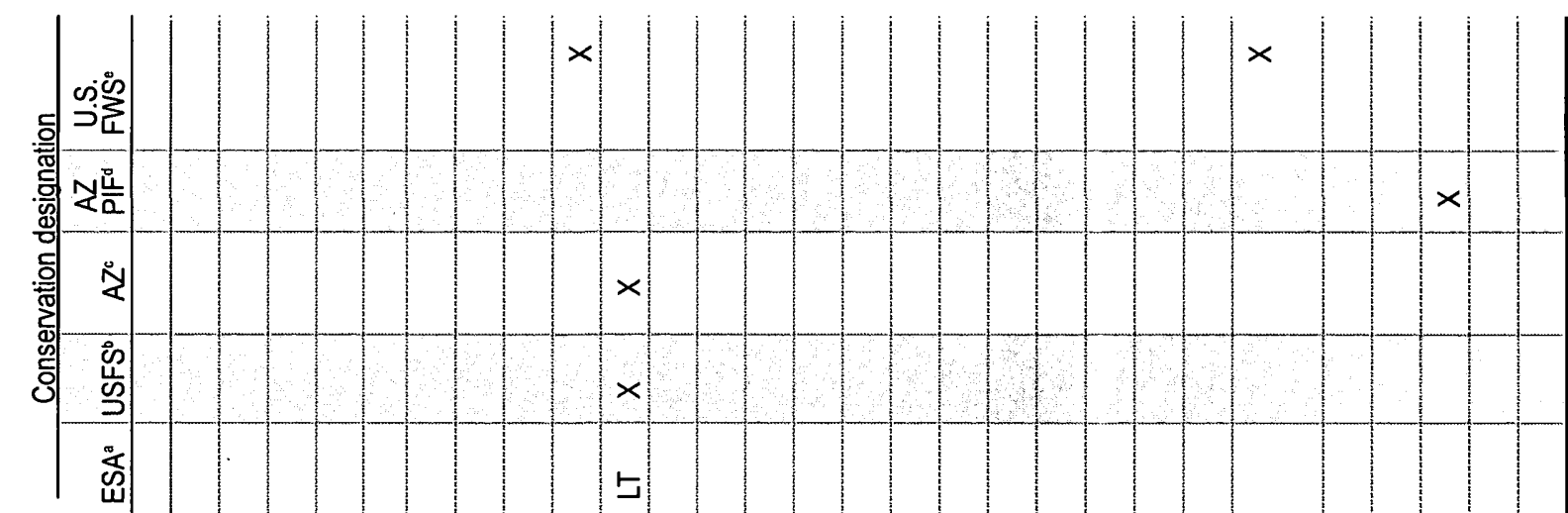

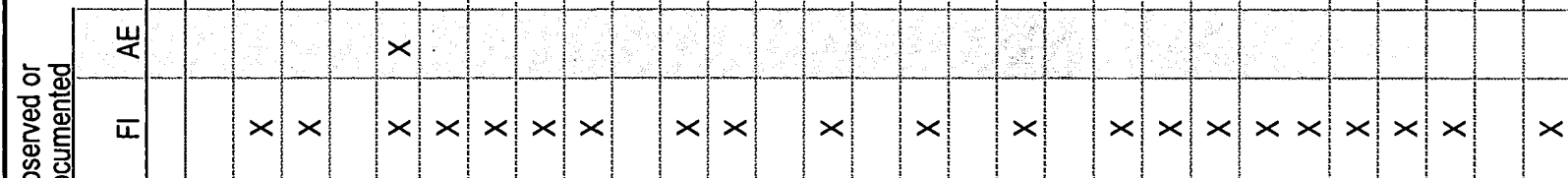

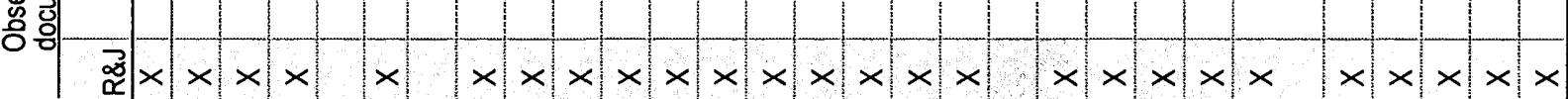

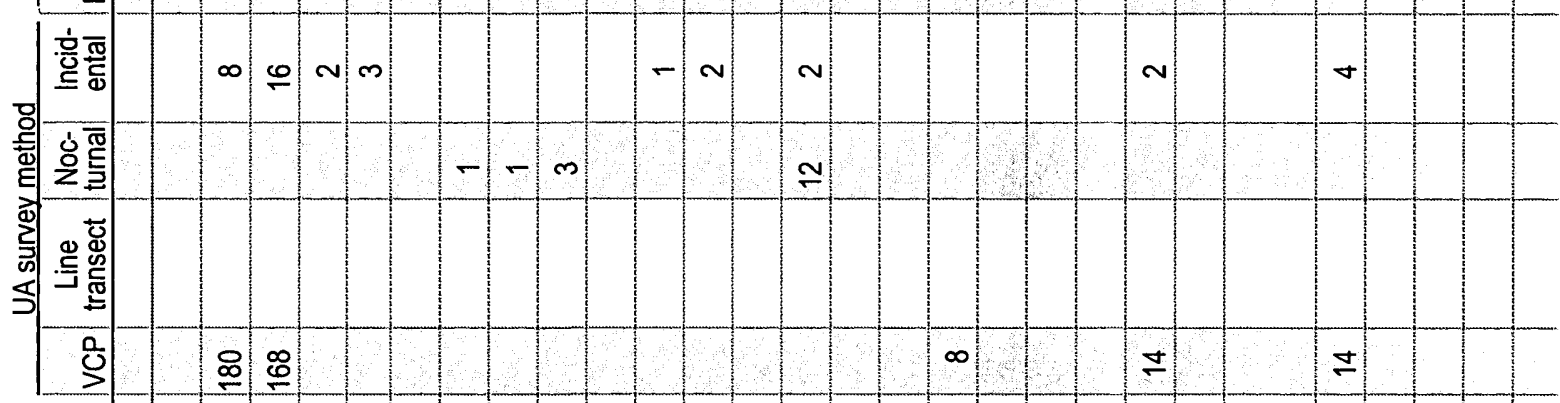

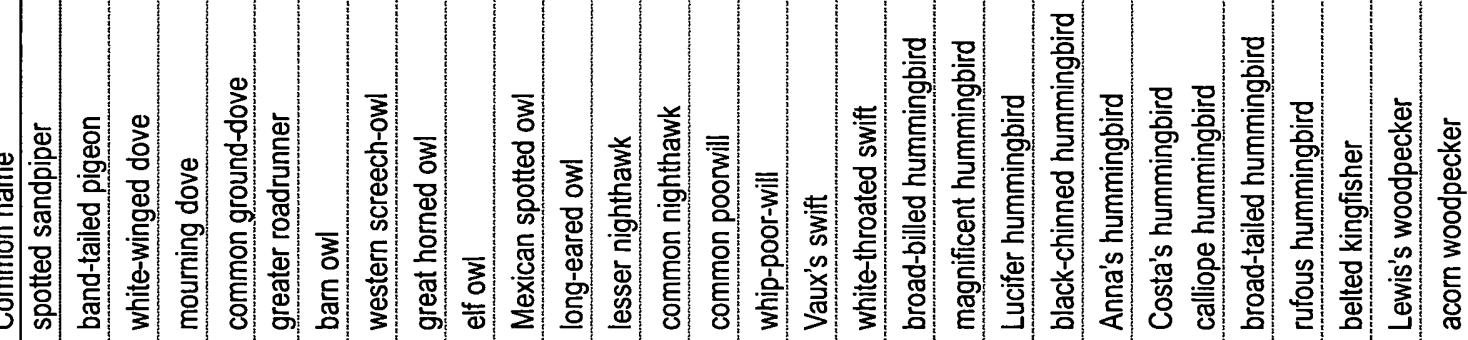

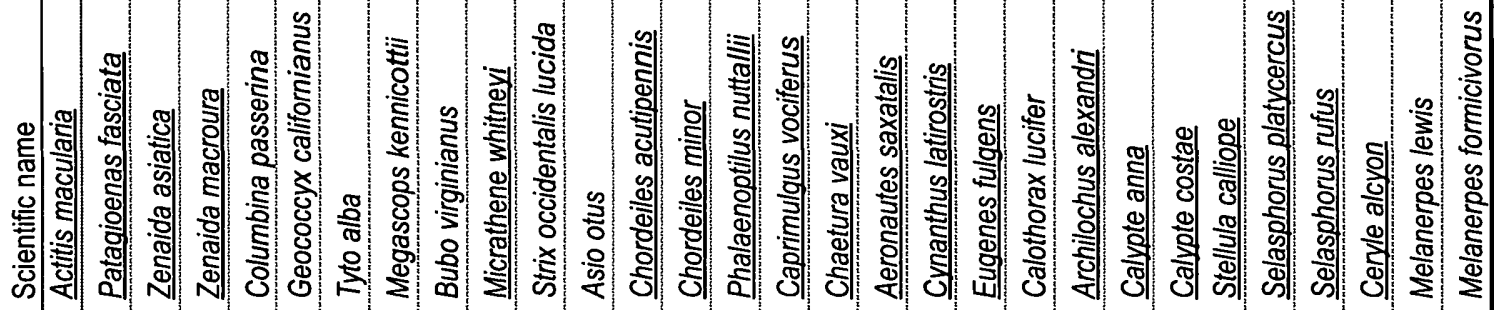

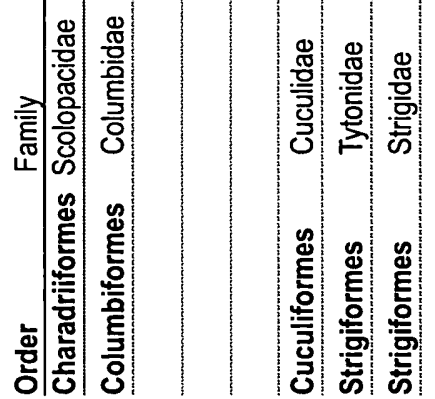

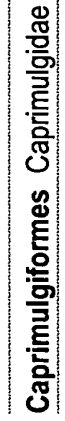
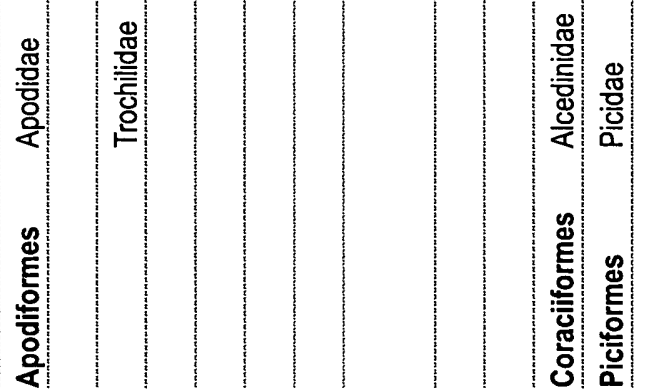


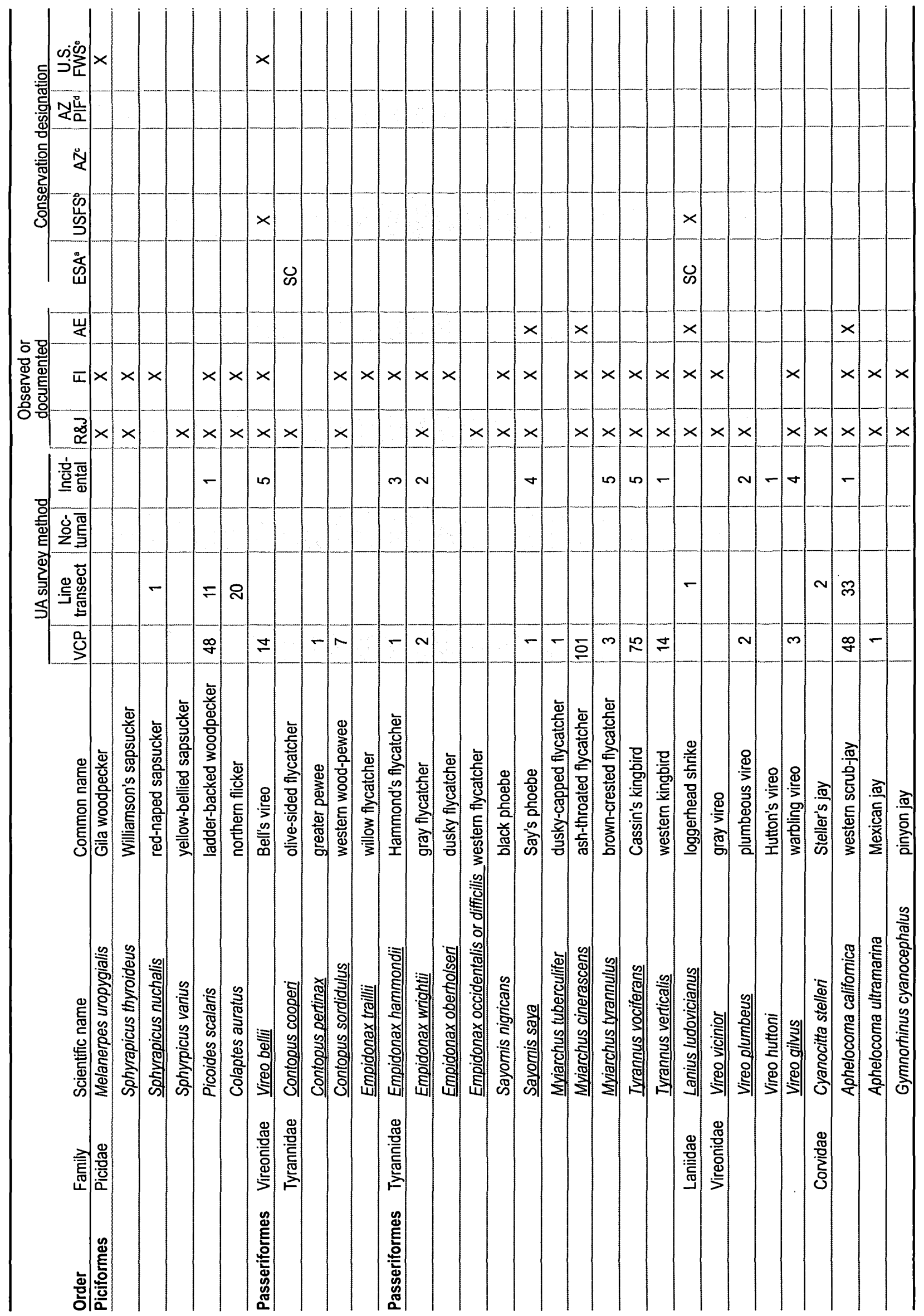




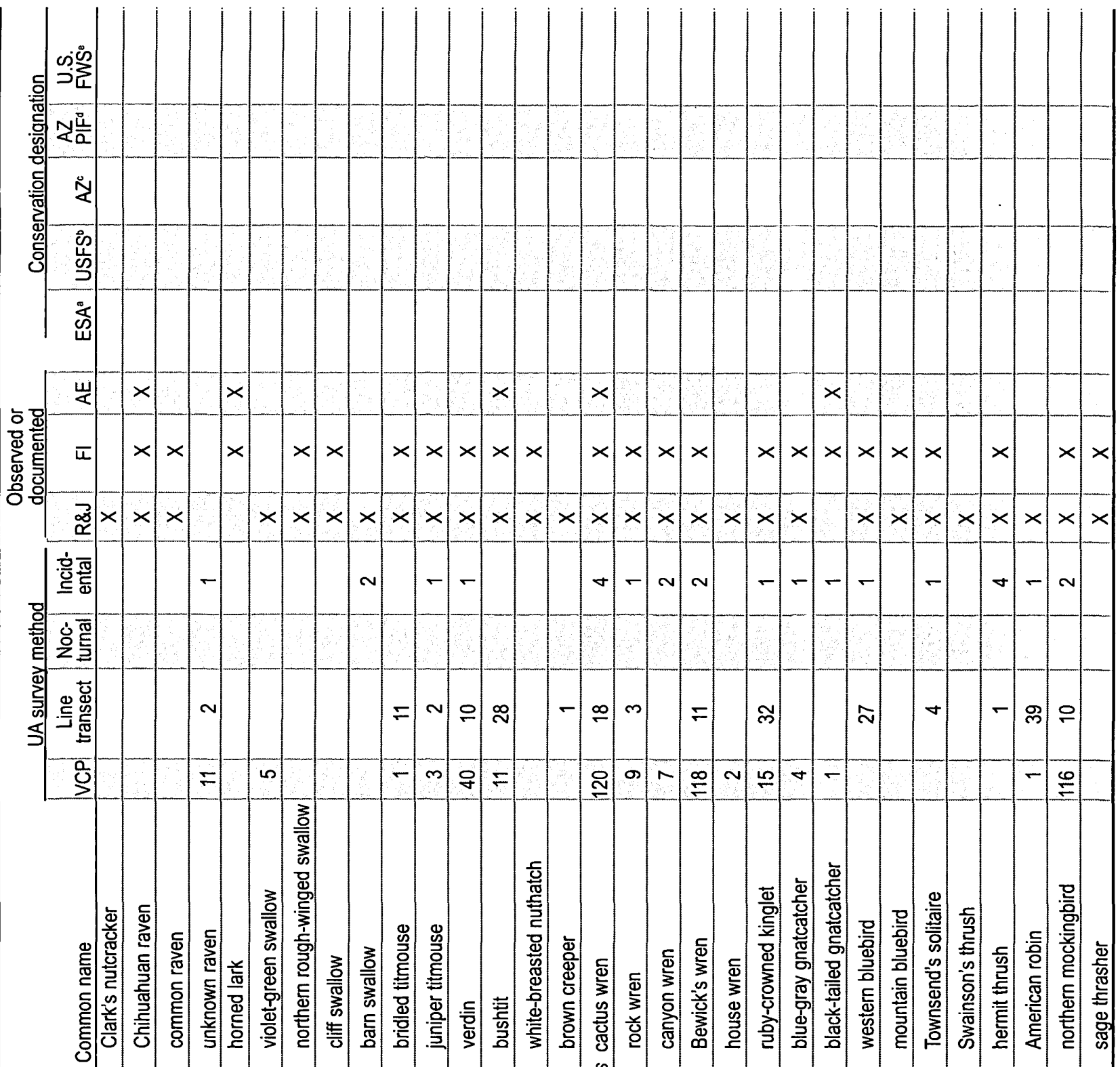

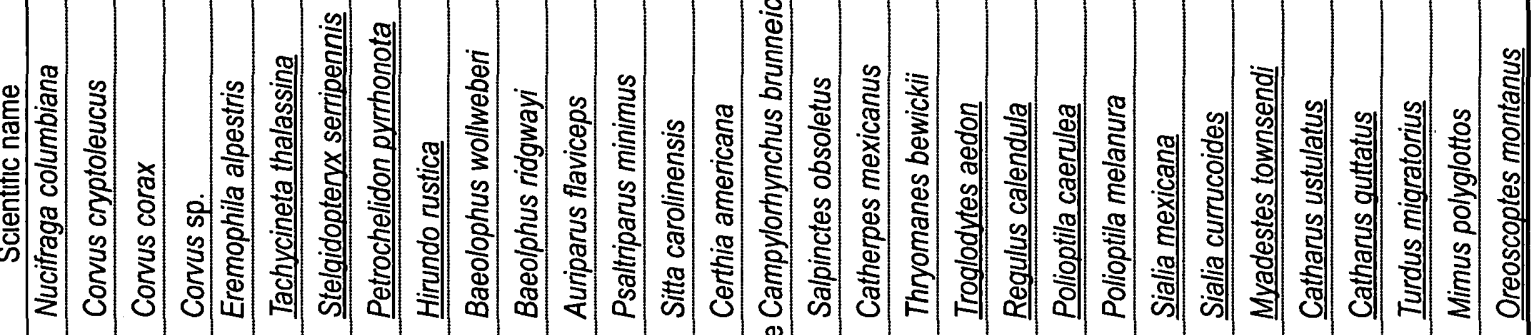

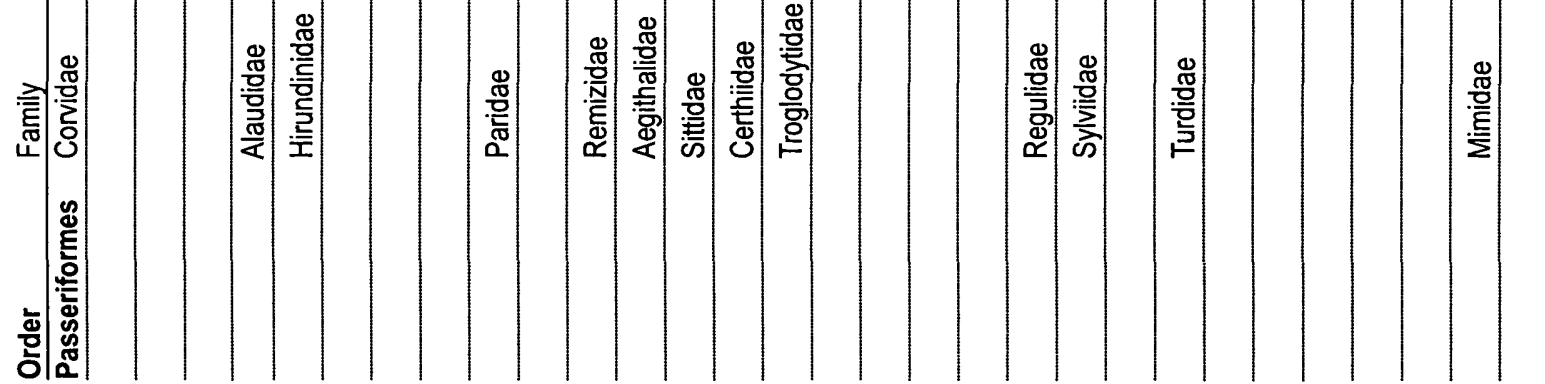




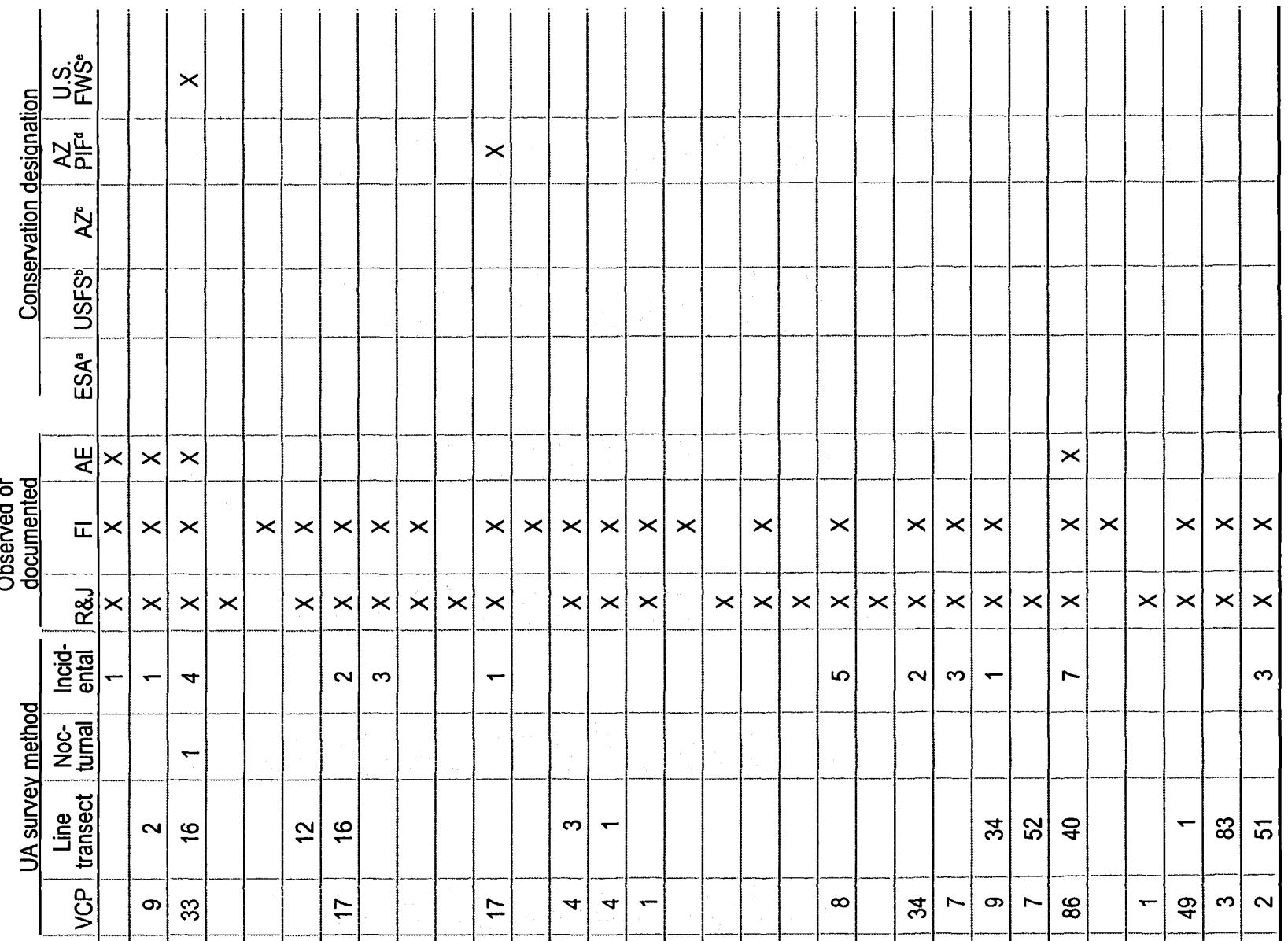

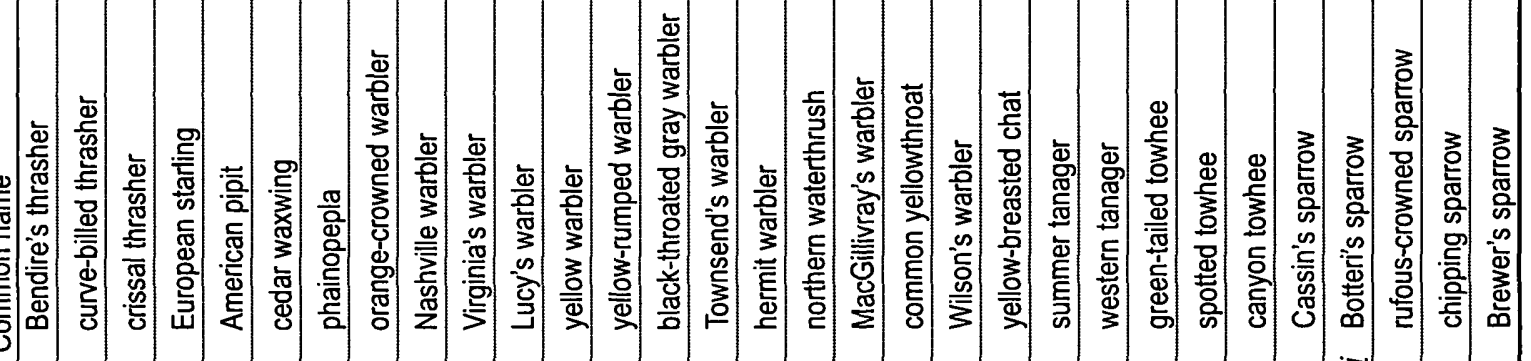

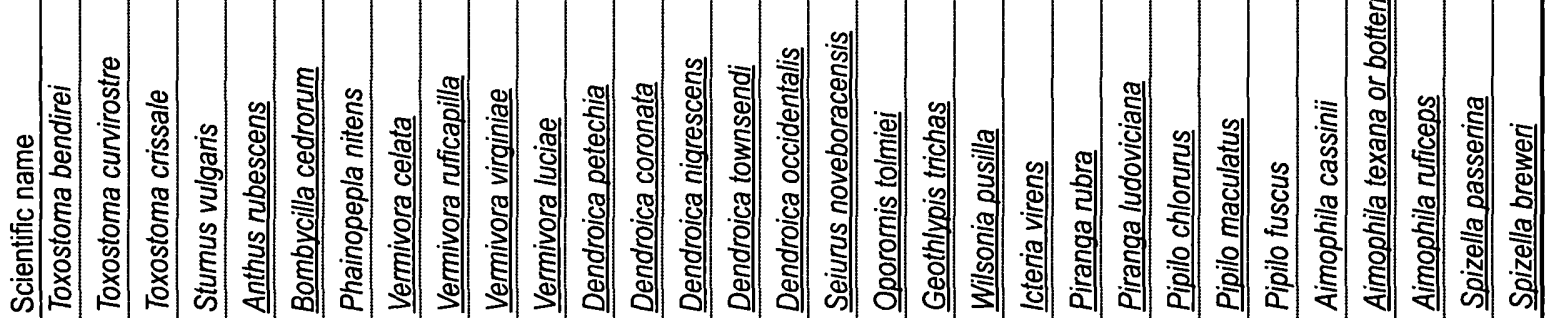

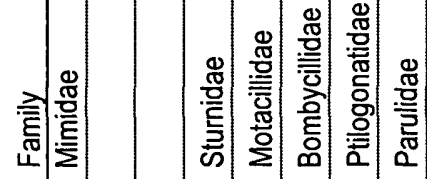

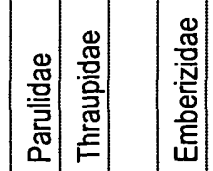

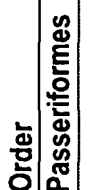




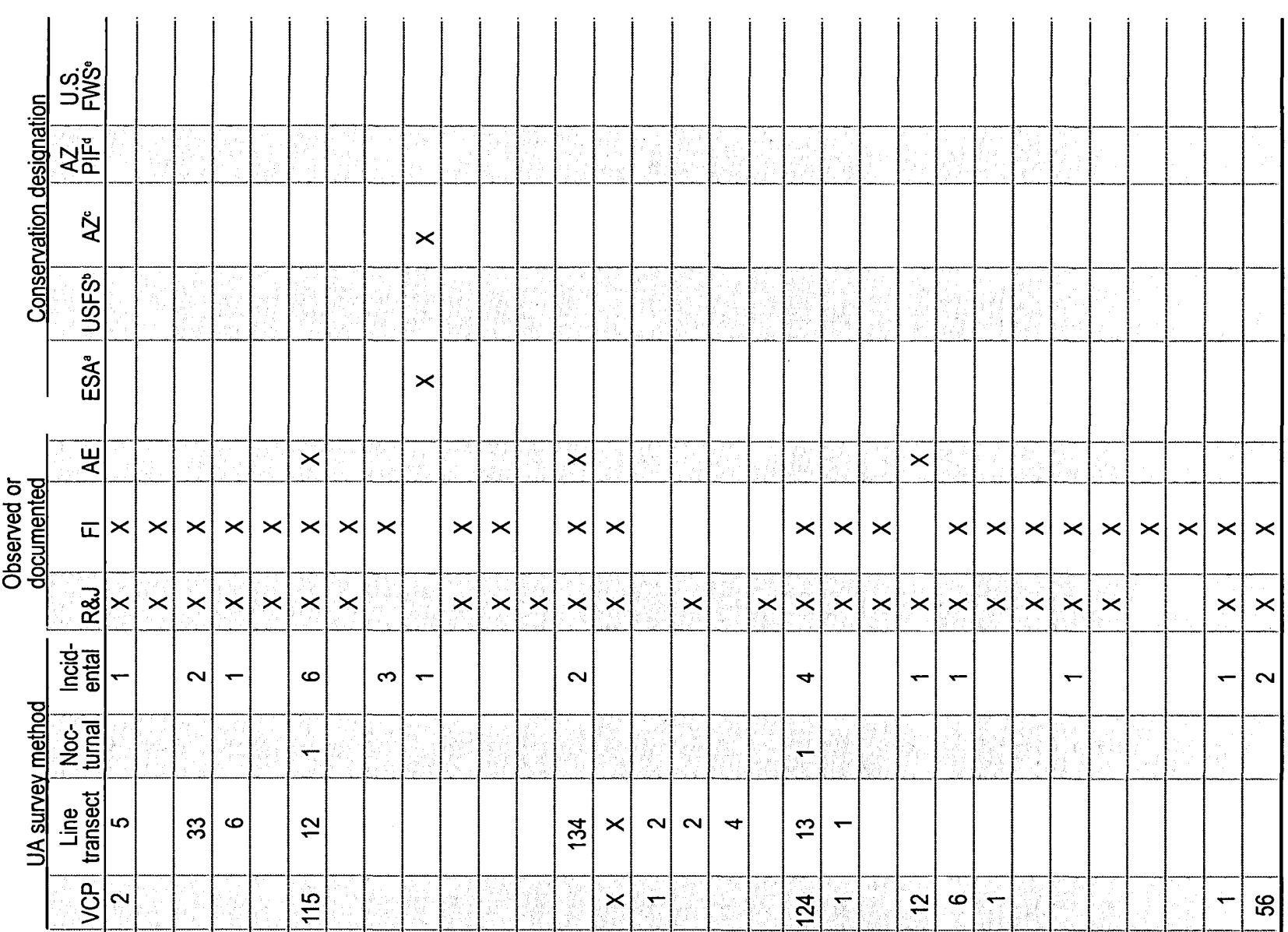

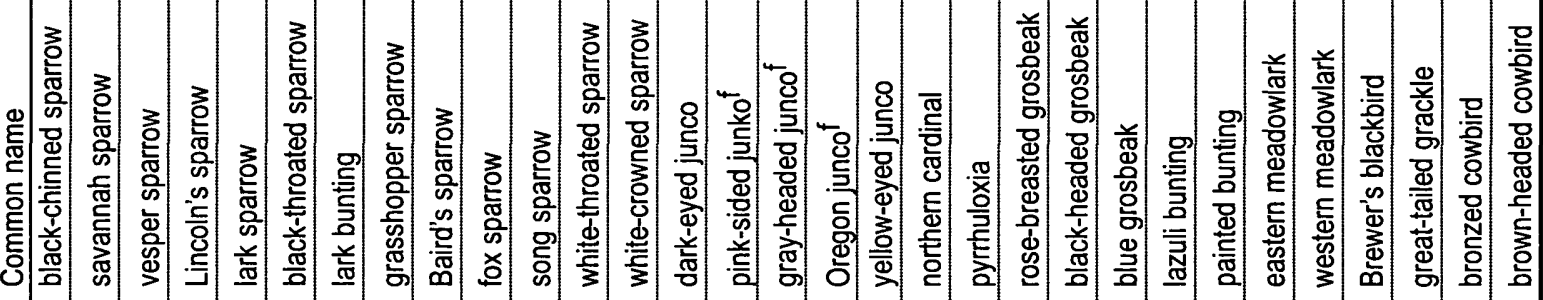

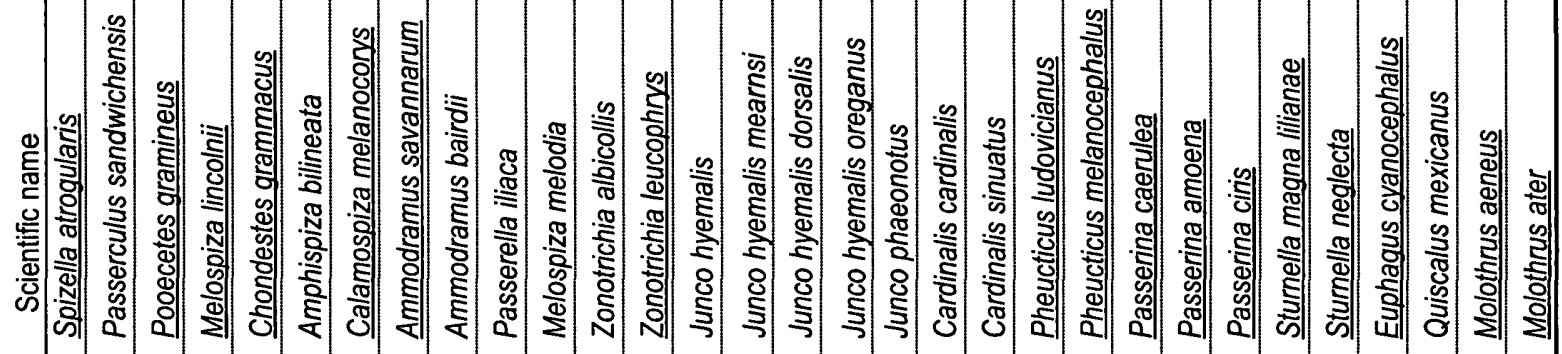

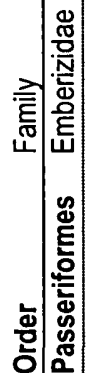

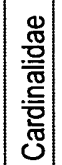




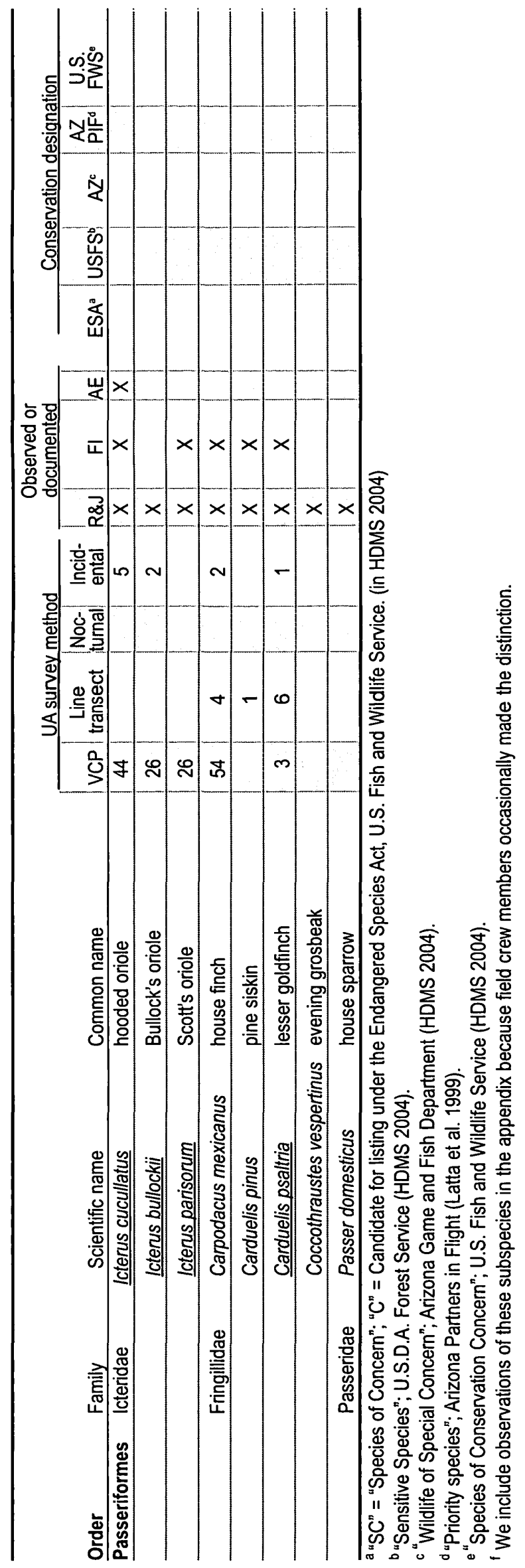


Appendix D. Mammals recorded at Fort Bowie NHS by University of Arizona inventory personnel (UA) and/or documented/observed by other researchers: Roth (1976; ROH), Petryszyn (1999; PZN), Herman-Reese (unpublished data; HR), Swann et al. (2001; SEA), Krebbs (2005; KRB), or specimens located in the UA mammal collection (UAMC). Species in bold-faced type is non-native.

\begin{tabular}{|c|c|c|c|c|c|c|c|c|c|}
\hline $\begin{array}{l}\text { Order } \\
\text { Family } \\
\end{array}$ & Scientific name & Common name & UA & UAMC & $\mathrm{ROH}$ & PZN & $\mathrm{HR}$ & SEA & KRB \\
\hline \multicolumn{10}{|l|}{ Insectivora } \\
\hline Soricidae & Notiosorex crawfordi & Crawford's desert shrew & & 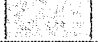 & $x$ & & & & \\
\hline \multicolumn{10}{|l|}{ Chiroptera } \\
\hline \multirow[t]{2}{*}{ Phyllostomidae } & Choeronycteris mexicana & Mexican long-tongued bat & & $x$ & $x$ & & & & \\
\hline & Leptonycteris curasoae yerbabuenae & lesser long-nosed bat & & $x$ & $x$ & & & & \\
\hline \multirow[t]{10}{*}{ Vespertilionidae } & Myotis occultus & Arizona myotis & & 8 & & & & & $x$ \\
\hline & Myotis auriculus & southwestern myotis & & & & & & & $x$ \\
\hline & Myotis velifer & cave myotis & & $x$ & $x$ & 1 & & & $x$ \\
\hline & Myotis thysanodes & fringed myotis & & $\mathrm{X}$ & $x$ & & & & $x$ \\
\hline & Myotis californicus & California myotis & & 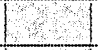 & & & & & $x$ \\
\hline & Myotis volans & long-legged myotis & & $x^{2}$ & & & & & $x$ \\
\hline & Myotis ciliolabrum & western small-footed myotis & & 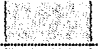 & & & & & $x$ \\
\hline & Pipistrellus hesperus & western pipistrelle & & $x$ & $\mathrm{x}$ & & & & \\
\hline & Eptesicus fuscus & big brown bat & & $x$ & & & & & \\
\hline & Antrozous pallidus & pallid bat & & $\mathrm{X}$ & $x$ & $E$ & & & \\
\hline \multicolumn{4}{|l|}{ Carnivora } & + & & 13 & & & \\
\hline Ursidae & Ursus americanus & American black bear & $x$ & $\sqrt{3}$ & & & $x$ & & \\
\hline \multirow[t]{3}{*}{ Procyonidae } & Procyon lotor & northern raccoon & & +3 & $x$ & 0 & & & \\
\hline & Nasua narica & white-nosed coati & $x$ & 2 & $x$ & & $x$ & & \\
\hline & Bassariscus astutus & ringtail & & $\underline{3}$ & $x$ & 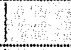 & $x$ & & \\
\hline \multirow[t]{5}{*}{ Mustelidae } & Taxidea taxus & American badger & & 8 & $x$ & & & $\mathrm{X}$ & \\
\hline & Mephitis macroura & hooded skunk & $x$ & $\sqrt{32}$ & & 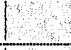 & & 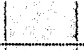 & \\
\hline & Spilogale gracilis & western spotted skunk & & 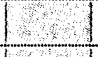 & $x$ & 1 & & & \\
\hline & Mephitis mephitis & striped skunk & $x$ & 5 & $x$ & 15 & $x$ & & \\
\hline & Conepatus mesoleucus & white-backed hog-nosed skunk & $x$ & 3 & $x$ & & & & \\
\hline \multirow[t]{3}{*}{ Canidae } & Canis familiaris & feral dog & $x$ & 4 & & 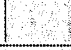 & & $=$ & \\
\hline & Canis latrans & coyote & $x$ & 8 & $x$ & & $x$ & $\mathrm{X}$ & \\
\hline & Urocyon cinereoargenteus & common gray fox & $x$ & 8 & $\mathrm{x}$ & & $x$ & $\mathrm{X}$ & \\
\hline \multirow[t]{2}{*}{ Felidae } & Lynx rufus & bobcat & $\mathrm{x}$ & 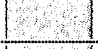 & $\mathrm{x}$ & & $x$ & $x$ & \\
\hline & Puma concolor & mountain lion & $x$ & +1 & & 4 & $x$ & $x$ & \\
\hline \multicolumn{10}{|l|}{ Rodentia } \\
\hline \multirow[t]{4}{*}{ Sciuridae } & Spermophilus variegatus & rock squirrel & $x$ & 1 & $x$ & & $x$ & $x$ & \\
\hline & Spermophilus tereticaudus & round-tailed ground squirrel & & $x$ & & & & & \\
\hline & Ammospermophilus harrisii & Harris' antelope squirrel & & $x$ & $x$ & & & $x$ & \\
\hline & Neotamias dorsalis & cliff chipmunk & & $x$ & $x$ & & & $x$ & \\
\hline Geomyidae & Thomomys bottae & Botta's pocket gopher & & $x$ & $x$ & & & & \\
\hline \multirow[t]{9}{*}{ Heteromyidae } & Perognathus flavus flavus & silky pocket mouse & & $x$ & $x$ & & $x$ & & \\
\hline & Perognathus amplus & Arizona pocket mouse & & 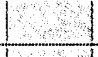 & & & $x$ & & \\
\hline & Chaetodipus penicillatus & Sonoran Desert pocket mouse & & $x$ & $x$ & $x$ & $x$ & & \\
\hline & Chaetodipus intermedius & rock pocket mouse & & $x$ & $x$ & & $x$ & & \\
\hline & Chaetodipus baileyi & Bailey's pocket mouse & & $x$ & $x$ & 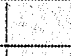 & $x$ & 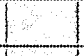 & \\
\hline & Chaetodipus hispidus & hispid pocket mouse & & $x$ & $x$ & & $x$ & & \\
\hline & Dipodomys spectabilis & banner-tailed kangaroo rat & & $x$ & $x$ & & & 1 & \\
\hline & Dipodomys ordii & Ord's kangaroo rat & & $x$ & $x$ & 8 & $x$ & & \\
\hline & Dipodomys merriami & Merriam's kangaroo rat & & 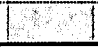 & $\mathrm{X}$ & $x$ & $x$ & & \\
\hline
\end{tabular}




\begin{tabular}{|c|c|c|c|c|c|c|c|c|c|}
\hline $\begin{array}{l}\text { Order } \\
\quad \text { Family } \\
\end{array}$ & Scientific name & Common name & UA & UAMC & $\mathrm{ROH}$ & PZN & $\mathrm{HR}$ & SEA & KRB \\
\hline \multicolumn{10}{|l|}{ Rodentia } \\
\hline \multirow[t]{3}{*}{ Heteromyidae } & Reithrodontomys megalotis megalotis & western harvest mouse & & & & & $x$ & & \\
\hline & Reithrodontomys fulvescens & fulvous harvest mouse & & $x$ & $\mathrm{x}$ & & & & \\
\hline & Peromyscus eremicus & cactus mouse & & $x$ & $\mathrm{x}$ & & $\mathrm{x}$ & & \\
\hline \multirow{8}{*}{ Muridae } & Peromyscus maniculatus & deer mouse & & $\mathrm{x}$ & $x$ & & $x$ & & \\
\hline & Peromyscus leucopus & white-footed mouse & & $x$ & & & & & \\
\hline & Peromyscus boylii & brush mouse & & $x$ & $x$ & & $x$ & & \\
\hline & Baiomys taylori & northern pygmy mouse & & & & & $x$ & & \\
\hline & Onychomys leucogaster & northern grasshopper mouse & & $x$ & $x$ & & $x$ & & \\
\hline & Onychomys torridus & southern grasshopper mouse & & $x$ & $x$ & $x$ & $x$ & & \\
\hline & Neotoma albigula & western white-throated woodrat & & $x$ & $\mathrm{x}$ & $\mathrm{x}$ & $\mathrm{x}$ & $x$ & \\
\hline & Sigmodon hispidus & hispid cotton rat & & $x$ & $x$ & & $x$ & & \\
\hline Erethizontidae & Erethizon dorsatum & North American porcupine & & 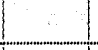 & & & & $x$ & \\
\hline \multicolumn{10}{|l|}{ Lagomorpha } \\
\hline \multirow[t]{3}{*}{ Leporidae } & Lepus alleni & antelope jackrabbit & & $x$ & $x$ & & & & \\
\hline & Lepus californicus & black-tailed jackrabbit & $\mathrm{x}$ & $\mathrm{x}$ & $\mathrm{x}$ & & & $x$ & \\
\hline & Sylvilagus audubonii & desert cottontail & & & $x$ & & & $\mathrm{X}$ & \\
\hline \multicolumn{10}{|l|}{ Artiodactyla } \\
\hline Tayassuidae & Pecari tajacu & collared peccary & $x$ & & $x$ & & $x$ & $x$ & \\
\hline \multirow[t]{2}{*}{ Cervidae } & Odocoileus hemionus & mule deer & $\mathrm{x}$ & & $\mathrm{x}$ & & $\mathrm{x}$ & $x$ & \\
\hline & Odocoileus virginianus & white-tailed deer & & & $x$ & & & $X$ & \\
\hline
\end{tabular}


Appendix E. List of voucher specimens collected from Fort Bowie NHS. See Table 1.1 for list of collections that were queried for specimens.

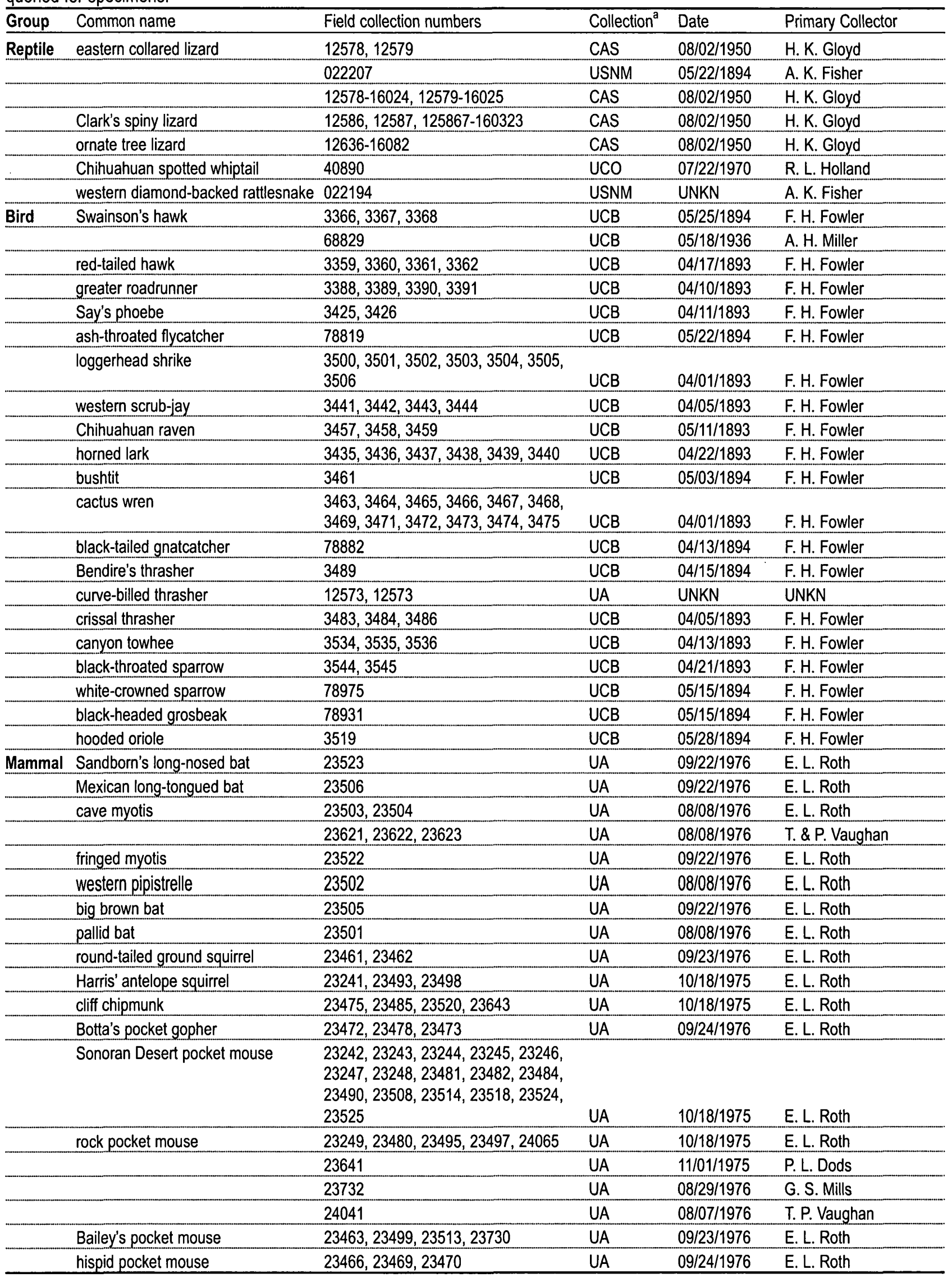




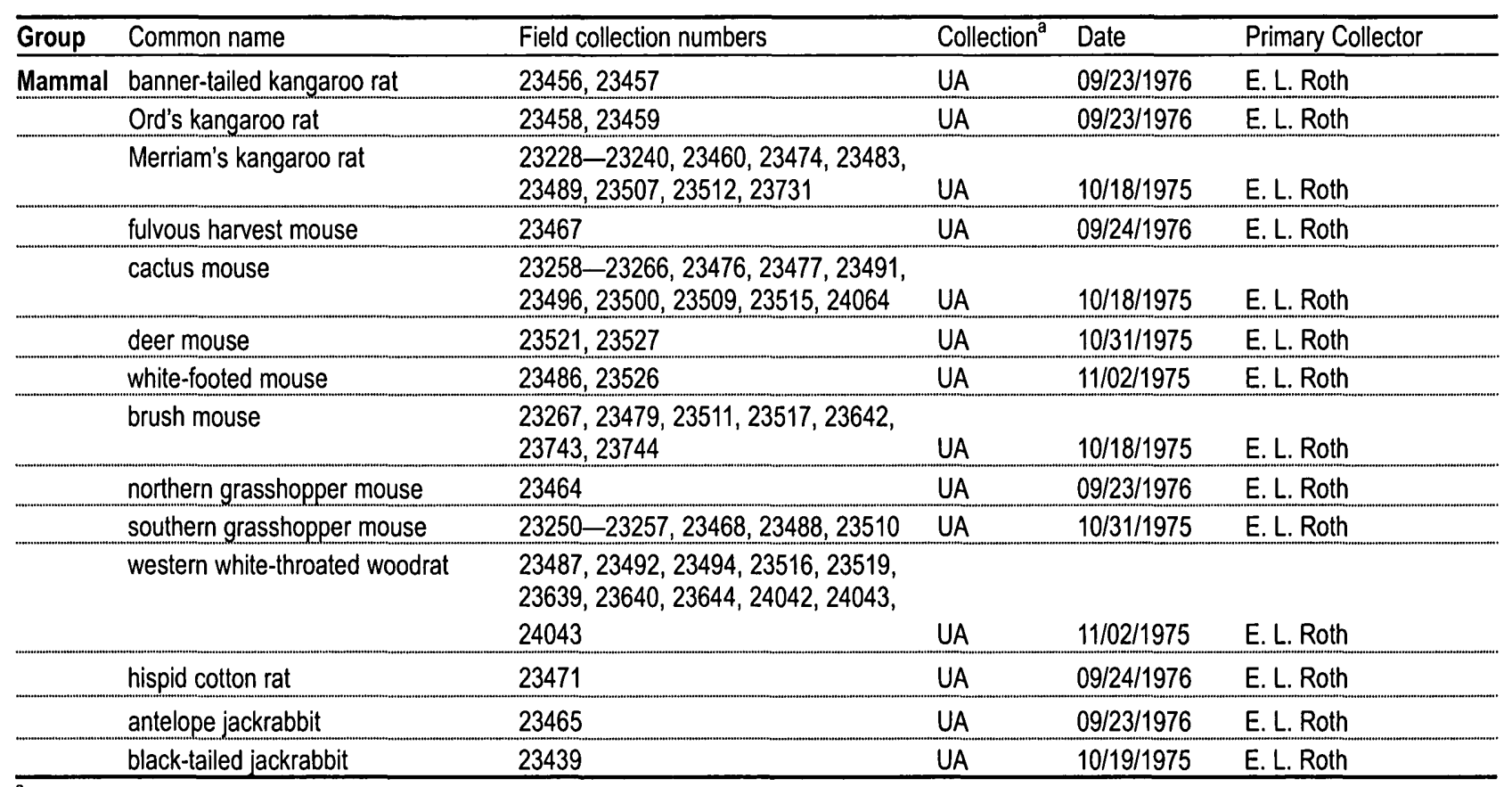

${ }^{\mathrm{a}}$ CAS = Chicago Academy of Sciences; USNM = U.S. National Museum; UCO = University of Colorado;

$U C B=$ University of California, Berkeley; UA = University of Arizona 
Appendix F. Summary of vegetation characteristics measured at bird survey stations, Fort Bowie NHS, 2004. See Appendix A for list of common names of plants.

\begin{tabular}{|c|c|c|c|}
\hline $\begin{array}{l}\text { Transect } \\
\text { Station }\end{array}$ & Category & Species & Mean density \\
\hline \multirow[t]{19}{*}{$\begin{array}{l}\text { Butter- } \\
\text { field } 1\end{array}$} & Subshrub & Gutierrezia sarothrae & 33.69 \\
\hline & & Haplopappus laricifolius & 67.39 \\
\hline & & Isocoma tenuisecta & 89.85 \\
\hline & & Prosopis velutina & 11.23 \\
\hline & & Sideroxylon lanuginosum & 22.46 \\
\hline & Shrub & Rhus microphylla & 5.19 \\
\hline & & Haplopappus laricifolius & 5.19 \\
\hline & & Opuntia spinosior & 5.19 \\
\hline & & Prosopis velutina & 23.36 \\
\hline & & Dasylirion wheeleri & 2.60 \\
\hline & & Nolina microcarpa & 2.60 \\
\hline & & Sideroxylon lanuginosum & 7.79 \\
\hline & Tree & Rhus microphylla & 2.69 \\
\hline & & Juniperus monosperma & 0.67 \\
\hline & & Juniperus osteosperma & 0.67 \\
\hline & & Prosopis velutina & 8.75 \\
\hline & & Celtis reticulata & 0.67 \\
\hline & Cavity & Juglans major & 2.38 \\
\hline & & Celtis reticulata & 0.79 \\
\hline \multirow[t]{25}{*}{2} & Subshrub & Yucca baccata & 121.36 \\
\hline & & Gutierrezia sarothrae & 40.45 \\
\hline & & Haplopappus laricifolius & 121.36 \\
\hline & & Isocoma tenuisecta & 161.82 \\
\hline & & Opuntia spinosior & 80.91 \\
\hline & & Arctostaphylos pungens & 121.36 \\
\hline & & Mimosa biuncifera & 80.91 \\
\hline & & Nolina microcarpa & 40.45 \\
\hline & Shrub & Yucca baccata & 22.40 \\
\hline & & Haplopappus laricifolius & 22.40 \\
\hline & & Juniperus monosperma & 22.40 \\
\hline & & Arctostaphylos pungens & 89.60 \\
\hline & & Mimosa biuncifera & 22.40 \\
\hline & & Prosopis velutina & 201.60 \\
\hline & & Quercus emoryi & 44.80 \\
\hline & & Dasylirion wheeleri & 22.40 \\
\hline & Tree & Juniperus deppeana & 3.46 \\
\hline & & Juniperus osteosperma & 6.93 \\
\hline & & Prosopis velutina & 20.78 \\
\hline & & Quercus emoryi & 24.24 \\
\hline & & Pinus edulis & 6.93 \\
\hline & & Celtis reticulata & 6.93 \\
\hline & Cavity & Juniperus deppeana & 1.96 \\
\hline & & Quercus emoryi & 4.58 \\
\hline & & Pinus edulis & 3.27 \\
\hline \multirow[t]{5}{*}{3} & Subshrub & Agave palmeri & 39.66 \\
\hline & & Yucca baccata & 39.66 \\
\hline & & Haplopappus laricifolius & 79.32 \\
\hline & & Isocoma tenuisecta & 19.83 \\
\hline & & Opuntia engelmannii & 19.83 \\
\hline
\end{tabular}

\begin{tabular}{|c|c|c|c|}
\hline $\begin{array}{l}\text { Transect } \\
\text { Station }\end{array}$ & Category & Species & Mean density \\
\hline \multirow[t]{21}{*}{3} & Subshrub & Opuntia spinosior & 19.83 \\
\hline & & Arctostaphylos pungens & 118.98 \\
\hline & & Dasylirion wheeleri & 19.83 \\
\hline & & Nolina microcarpa & 39.66 \\
\hline & Shrub & Arctostaphylos pungens & 153.35 \\
\hline & & Mimosa biuncifera & 19.17 \\
\hline & & Prosopis velutina & 57.51 \\
\hline & & Quercus arizonica & 19.17 \\
\hline & & Quercus emoryi & 57.51 \\
\hline & & Quercus sp. & 19.17 \\
\hline & & Nolina microcarpa & 57.51 \\
\hline & Tree & Juniperus osteosperma & 1.85 \\
\hline & & Arctostaphylos pungens & 1.85 \\
\hline & & Prosopis velutina & 1.85 \\
\hline & & Quercus arizonica & 1.85 \\
\hline & & Quercus emoryi & 27.67 \\
\hline & & Pinus edulis & 1.85 \\
\hline & Cavity & Juniperus osteosperma & 2.01 \\
\hline & & Quercus arizonica & 2.01 \\
\hline & & Quercus emoryi & 24.13 \\
\hline & & Quercus sp. & 2.01 \\
\hline \multirow[t]{17}{*}{4} & Subshrub & Agave palmeri & 31.66 \\
\hline & & Yucca baccata & 63.33 \\
\hline & & Haplopappus laricifolius & 348.31 \\
\hline & & Arctostaphylos pungens & 63.33 \\
\hline & & Prosopis velutina & 94.99 \\
\hline & & Dasylirion wheeleri & 31.66 \\
\hline & Shrub & Yucca baccata & 9.91 \\
\hline & & Arctostaphylos pungens & 39.63 \\
\hline & & Prosopis velutina & 59.44 \\
\hline & & Quercus emoryi & 19.81 \\
\hline & & Dasylirion wheeleri & 9.91 \\
\hline & & Nolina microcarpa & 59.44 \\
\hline & Tree & Juniperus monosperma & 4.05 \\
\hline & & Prosopis velutina & 10.13 \\
\hline & & Quercus emoryi & 26.34 \\
\hline & Cavity & Quercus arizonica & 1.66 \\
\hline & & Quercus emoryi & 19.90 \\
\hline \multirow[t]{12}{*}{5} & Subshrub & Gutierrezia sarothrae & 88.61 \\
\hline & & Haplopappus laricifolius & 443.07 \\
\hline & & Arctostaphylos pungens & 88.61 \\
\hline & & Dasylirion wheeleri & 132.92 \\
\hline & & Nolina microcarpa & 132.92 \\
\hline & Shrub & Yucca baccata & 16.80 \\
\hline & & Juniperus deppeana & 16.80 \\
\hline & & Juniperus monosperma & 16.80 \\
\hline & & Arctostaphylos pungens & 100.80 \\
\hline & & Prosopis velutina & 16.80 \\
\hline & & Quercus arizonica & 16.80 \\
\hline & & Quercus emoryi & 16.80 \\
\hline
\end{tabular}




\begin{tabular}{|c|c|c|c|}
\hline $\begin{array}{l}\text { Transect } \\
\text { Station }\end{array}$ & Category & Species & Mean density \\
\hline \multirow[t]{10}{*}{5} & Shrub & Dasylirion wheeleri & 117.60 \\
\hline & & Nolina microcarpa & 16.80 \\
\hline & Tree & Juniperus monosperma & 4.92 \\
\hline & & Quercus arizonica & 4.92 \\
\hline & & Quercus emoryi & 7.87 \\
\hline & & Garrya flavescens & 1.97 \\
\hline & Cavity & Juniperus monosperma & 0.63 \\
\hline & & Quercus arizonica & 1.90 \\
\hline & & Quercus emoryi & 6.96 \\
\hline & & Quercus sp. & 1.90 \\
\hline \multirow[t]{18}{*}{6} & Subshrub & Yucca baccata & 2.85 \\
\hline & & Haplopappus laricifolius & 14.23 \\
\hline & & Opuntia spinosior & 1.42 \\
\hline & & Arctostaphylos pungens & 1.42 \\
\hline & & Mimosa biuncifera & 1.42 \\
\hline & & Quercus emoryi & 4.27 \\
\hline & & Nolina microcarpa & 2.85 \\
\hline & Shrub & Agave palmeri & 14.56 \\
\hline & & Arctostaphylos pungens & 58.22 \\
\hline & & Mimosa biuncifera & 29.11 \\
\hline & & Prosopis velutina & 72.78 \\
\hline & & Quercus emoryi & 14.56 \\
\hline & & Nolina microcarpa & 101.89 \\
\hline & Tree & Juniperus monosperma & 11.25 \\
\hline & & Prosopis velutina & 3.75 \\
\hline & & Quercus emoryi & 22.50 \\
\hline & Cavity & Quercus emoryi & 5.54 \\
\hline & & Quercus sp. & 0.40 \\
\hline \multirow[t]{20}{*}{7} & Subshrub & Yucca baccata & 139.84 \\
\hline & & Baccharis sarothroides & 69.92 \\
\hline & & Haplopappus laricifolius & 559.34 \\
\hline & & Opuntia spinosior & 139.84 \\
\hline & & Arctostaphylos pungens & 209.75 \\
\hline & & Mimosa biuncifera & 69.92 \\
\hline & & Nolina microcarpa & 209.75 \\
\hline & Shrub & Yucca baccata & 14.99 \\
\hline & & Juniperus monosperma & 14.99 \\
\hline & & Arctostaphylos pungens & 44.97 \\
\hline & & Mimosa biuncifera & 14.99 \\
\hline & & Prosopis velutina & 29.98 \\
\hline & & Nolina microcarpa & 179.86 \\
\hline & Tree & Juniperus monosperma & 6.49 \\
\hline & & Prosopis velutina & 2.60 \\
\hline & & Quercus emoryi & 16.87 \\
\hline & Cavity & Juniperus monosperma & 0.61 \\
\hline & & Quercus arizonica & 1.82 \\
\hline & & Quercus emoryi & 6.06 \\
\hline & & Quercus sp. & 0.61 \\
\hline \multirow[t]{6}{*}{8} & Subshrub & Agave palmeri & 123.43 \\
\hline & & Haplopappus laricifolius & 617.13 \\
\hline & & Mimosa biuncifera & 431.99 \\
\hline & & Dasylirion wheeleri & 61.71 \\
\hline & Shrub & Agave palmeri & 1.46 \\
\hline & & Juniperus monosperma & 2.91 \\
\hline
\end{tabular}

\begin{tabular}{|c|c|c|c|}
\hline $\begin{array}{l}\text { Transect } \\
\text { Station } \\
\end{array}$ & Category & Species & Mean density \\
\hline \multirow[t]{12}{*}{8} & Shrub & Mimosa biuncifera & 10.19 \\
\hline & & Prosopis velutina & 4.37 \\
\hline & & Dasylirion wheeleri & 2.91 \\
\hline & & Nolina microcarpa & 7.28 \\
\hline & Tree & Juniperus monosperma & 6.00 \\
\hline & & Prosopis velutina & 1.50 \\
\hline & & Quercus arizonica & 2.25 \\
\hline & & Quercus emoryi & 4.50 \\
\hline & & Garrya flavescens & 0.75 \\
\hline & Cavity & Juniperus deppeana & 0.24 \\
\hline & & Quercus arizonica & 0.94 \\
\hline & & Quercus emoryi & 2.83 \\
\hline \multicolumn{4}{|c|}{ Siphon Canyon } \\
\hline \multirow[t]{39}{*}{1} & Subshrub & Agave palmeri & 172.80 \\
\hline & & Yucca baccata & 691.19 \\
\hline & & Chrysothamnus nauseosus & 172.80 \\
\hline & & Gutierrezia sarothrae & 345.59 \\
\hline & & Haplopappus laricifolius & 518.39 \\
\hline & & Parthenium incanum & 518.39 \\
\hline & & Juniperus osteosperma & 172.80 \\
\hline & & Mimosa biuncifera & 172.80 \\
\hline & & Garrya flavescens & 172.80 \\
\hline & & Nolina microcarpa & 172.80 \\
\hline & & Sideroxylon lanuginosum & 345.59 \\
\hline & Shrub & Rhus microphylla & 170.36 \\
\hline & & Haplopappus laricifolius & 56.79 \\
\hline & & Juniperus osteosperma & 56.79 \\
\hline & & Mimosa biuncifera & 113.58 \\
\hline & & Prosopis velutina & 56.79 \\
\hline & & Quercus arizonica & 113.58 \\
\hline & & Quercus turbinella & 170.36 \\
\hline & & Garrya flavescens & 113.58 \\
\hline & & Sapindus saponaria & 56.79 \\
\hline & & Sideroxylon lanuginosum & 170.36 \\
\hline & & Celtis reticulata & 56.79 \\
\hline & Tree & Juniperus monosperma & 8.13 \\
\hline & & Juniperus osteosperma & 8.13 \\
\hline & & Prosopis velutina & 8.13 \\
\hline & & Quercus arizonica & 4.07 \\
\hline & & Quercus turbinella & 8.13 \\
\hline & & Fouquieria splendens & 8.13 \\
\hline & & Garrya flavescens & 12.20 \\
\hline & & Sapindus saponaria & 4.07 \\
\hline & & Sideroxylon lanuginosum & 12.20 \\
\hline & & Celtis reticulata & 8.13 \\
\hline & Cavity & Juniperus monosperma & 2.15 \\
\hline & & Juniperus osteosperma & 4.31 \\
\hline & & Quercus arizonica & 8.62 \\
\hline & & Quercus sp. & 2.15 \\
\hline & & Juglans major & 2.15 \\
\hline & & Fraxinus velutina & 10.77 \\
\hline & & Celtis reticulata & 2.15 \\
\hline \multirow[t]{2}{*}{2} & Subshrub & Unknown species & 81.73 \\
\hline & & Gutierrezia sarothrae & 81.73 \\
\hline
\end{tabular}




\begin{tabular}{|c|c|c|c|}
\hline $\begin{array}{l}\text { Transect } \\
\text { Station }\end{array}$ & Category & Species & Mean density \\
\hline \multirow[t]{24}{*}{2} & Subshrub & Haplopappus laricifolius & 163.46 \\
\hline & & Isocoma tenuisecta & 245.19 \\
\hline & & Opuntia engelmannii & 81.73 \\
\hline & & Opuntia spinosior & 163.46 \\
\hline & & Prosopis velutina & 81.73 \\
\hline & & Sideroxylon lanuginosum & 572.10 \\
\hline & & Celtis reticulata & 163.46 \\
\hline & Shrub & Rhus microphylla & 237.17 \\
\hline & & Baccharis sarothroides & 79.06 \\
\hline & & Opuntia engelmannii & 158.12 \\
\hline & & Prosopis velutina & 474.34 \\
\hline & & Sideroxylon lanuginosum & 474.34 \\
\hline & & Celtis reticulata & 158.12 \\
\hline & Tree & Rhus microphylla & 4.19 \\
\hline & & Juniperus monosperma & 8.39 \\
\hline & & Prosopis velutina & 29.36 \\
\hline & & Fouquieria splendens & 8.39 \\
\hline & & Sideroxylon lanuginosum & 20.97 \\
\hline & & Celtis reticulata & 12.58 \\
\hline & Cavity & Juniperus monosperma & 4.66 \\
\hline & & Prosopis velutina & 1.55 \\
\hline & & Quercus arizonica & 2.33 \\
\hline & & Juglans major & 0.78 \\
\hline & & Celtis reticulata & 4.66 \\
\hline \multirow[t]{27}{*}{3} & Subshrub & Rhus microphylla & 29.36 \\
\hline & & Brickellia sp. & 88.08 \\
\hline & & Gutierrezia sarothrae & 117.44 \\
\hline & & Haplopappus laricifolius & 29.36 \\
\hline & & Isocoma tenuisecta & 117.44 \\
\hline & & Opuntia engelmannii & 58.72 \\
\hline & & Opuntia spinosior & 58.72 \\
\hline & & Datura meteloides & 58.72 \\
\hline & & Celtis reticulata & 29.36 \\
\hline & Shrub & Unknown species & 6.01 \\
\hline & & Rhus microphylla & 6.01 \\
\hline & & Haplopappus laricifolius & 18.02 \\
\hline & & Chilopsis linearis & 24.02 \\
\hline & & Opuntia spinosior & 12.01 \\
\hline & & Prosopis velutina & 18.02 \\
\hline & & Sideroxylon lanuginosum & 6.01 \\
\hline & & Lycium pallidum & 6.01 \\
\hline & & Celtis reticulata & 24.02 \\
\hline & Tree & Rhus microphylla & 16.68 \\
\hline & & Chilopsis linearis & 16.68 \\
\hline & & Prosopis velutina & 20.02 \\
\hline & & Juglans major & 3.34 \\
\hline & & Celtis reticulata & 10.01 \\
\hline & Cavity & Chilopsis linearis & 5.38 \\
\hline & & Prosopis velutina & 2.69 \\
\hline & & Quercus emoryi & 1.35 \\
\hline & & Juglans major & 5.38 \\
\hline 3 & Cavity & Celtis reticulata & 4.04 \\
\hline \multirow[t]{2}{*}{4} & Subshrub & Brickellia sp. & 41.67 \\
\hline & & Gutierrezia sarothrae & 20.84 \\
\hline
\end{tabular}

\begin{tabular}{|c|c|c|c|}
\hline $\begin{array}{l}\text { Transect } \\
\text { Station }\end{array}$ & Category & Species & Mean density \\
\hline \multirow[t]{18}{*}{4} & Subshrub & Haplopappus laricifolius & 31.26 \\
\hline & & Opuntia spinosior & 20.84 \\
\hline & & Ephedra sp. & 10.42 \\
\hline & & Sideroxylon lanuginosum & 83.35 \\
\hline & Shrub & Rhus microphylla & 105.49 \\
\hline & & Brickellia sp. & 70.32 \\
\hline & & Prosopis velutina & 35.16 \\
\hline & & Sideroxylon lanuginosum & 140.65 \\
\hline & Tree & Rhus microphylla & 20.93 \\
\hline & & Prosopis velutina & 34.88 \\
\hline & & Juglans major & 6.98 \\
\hline & & Sideroxylon lanuginosum & 27.90 \\
\hline & & Celtis reticulata & 48.83 \\
\hline & Cavity & Chilopsis linearis & 11.21 \\
\hline & & Prosopis velutina & 3.74 \\
\hline & & Juglans major & 3.74 \\
\hline & & Sideroxylon lanuginosum & 3.74 \\
\hline & & Celtis reticulata & 44.86 \\
\hline \multirow[t]{28}{*}{5} & Subshrub & Anisacanthus thurberi & 15.71 \\
\hline & & Rhus microphylla & 31.42 \\
\hline & & Brickellia sp. & 47.13 \\
\hline & & Chrysothamnus nauseosus & 15.71 \\
\hline & & Gutierrezia sarothrae & 15.71 \\
\hline & & Isocoma tenuisecta & 47.13 \\
\hline & & Parthenium incanum & 31.42 \\
\hline & & Prosopis velutina & 47.13 \\
\hline & & Garrya flavescens & 15.71 \\
\hline & & Sideroxylon lanuginosum & 31.42 \\
\hline & & Lycium pallidum & 15.71 \\
\hline & Shrub & Rhus microphylla & 4.43 \\
\hline & & Brickellia sp. & 2.22 \\
\hline & & Chilopsis linearis & 2.22 \\
\hline & & Prosopis velutina & 13.30 \\
\hline & & Sideroxylon lanuginosum & 15.52 \\
\hline & & Celtis reticulata & 4.43 \\
\hline & & Larrea tridentata & 2.22 \\
\hline & Tree & Chilopsis linearis & 3.07 \\
\hline & & Juniperus monosperma & 1.54 \\
\hline & & Prosopis velutina & 10.75 \\
\hline & & Fouquieria splendens & 3.07 \\
\hline & & Sideroxylon lanuginosum & 9.22 \\
\hline & & Celtis reticulata & 3.07 \\
\hline & Cavity & Chilopsis linearis & 3.08 \\
\hline & & Prosopis velutina & 3.08 \\
\hline & & Juglans major & 6.16 \\
\hline & & Celtis reticulata & 10.78 \\
\hline \multirow[t]{8}{*}{6} & Subshrub & Brickellia sp. & 34.33 \\
\hline & & Chrysothamnus nauseosus & 45.77 \\
\hline & & Parthenium incanum & 22.89 \\
\hline & & Opuntia engelmannii & 34.33 \\
\hline & & Opuntia spinosior & 22.89 \\
\hline & & Juglans major & 11.44 \\
\hline & & Sideroxylon lanuginosum & 45.77 \\
\hline & & Lycium pallidum & 11.44 \\
\hline
\end{tabular}




\begin{tabular}{|c|c|c|c|}
\hline $\begin{array}{l}\text { Transect } \\
\text { Station } \\
\end{array}$ & Category & Species & Mean density \\
\hline \multirow[t]{22}{*}{6} & Shrub & Rhus microphylla & 15.12 \\
\hline & & Chrysothamnus nauseosus & 90.72 \\
\hline & & Chilopsis linearis & 30.24 \\
\hline & & Atriplex canescens & 45.36 \\
\hline & & Prosopis velutina & 15.12 \\
\hline & & Nolina microcarpa & 15.12 \\
\hline & & Sideroxylon lanuginosum & 75.60 \\
\hline & & Lycium pallidum & 15.12 \\
\hline & Tree & Rhus microphylla & 9.33 \\
\hline & & Chilopsis linearis & 32.65 \\
\hline & & Juniperus monosperma & 4.67 \\
\hline & & Prosopis velutina & 13.99 \\
\hline & & Fouquieria splendens & 9.33 \\
\hline & & Juglans major & 4.67 \\
\hline & & Condalia warnockii & 4.67 \\
\hline & & Celtis reticulata & 13.99 \\
\hline & Cavity & Chilopsis linearis & 1.39 \\
\hline & & Juniperus monosperma & 0.35 \\
\hline & & Juglans major & 1.39 \\
\hline & & Pinus edulis & 0.35 \\
\hline & & Sideroxylon lanuginosum & 0.35 \\
\hline & & Celtis reticulata & 2.44 \\
\hline \multirow[t]{25}{*}{7} & Subshrub & Rhus microphylla & 41.00 \\
\hline & & Baccharis sarothroides & 20.50 \\
\hline & & Brickellia sp. & 20.50 \\
\hline & & Haplopappus laricifolius & 20.50 \\
\hline & & Opuntia engelmannii & 20.50 \\
\hline & & Juniperus osteosperma & 20.50 \\
\hline & & Acacia greggii & 61.50 \\
\hline & & Morus microphylla & 41.00 \\
\hline & & Ziziphus obtusifolia & 20.50 \\
\hline & & Ptelea trifoliata & 20.50 \\
\hline & & Sideroxylon lanuginosum & 41.00 \\
\hline & & Lycium pallidum & 20.50 \\
\hline & & Celtis reticulata & 61.50 \\
\hline & Shrub & Rhus microphylla & 88.51 \\
\hline & & Baccharis sarothroides & 59.00 \\
\hline & & Acacia greggii & 118.01 \\
\hline & & Ziziphus obtusifolia & 88.51 \\
\hline & & Sideroxylon lanuginosum & 118.01 \\
\hline & & Celtis reticulata & 118.01 \\
\hline & Tree & Rhus microphylla & 15.73 \\
\hline & & Juniperus monosperma & 3.15 \\
\hline & & Fouquieria splendens & 3.15 \\
\hline & & Morus microphylla & 3.15 \\
\hline & & Sideroxylon lanuginosum & 3.15 \\
\hline & & Celtis reticulata & 25.17 \\
\hline \multirow[t]{5}{*}{7} & Tree & Juniperus osteosperma & 0.60 \\
\hline & & Juglans major & 2.97 \\
\hline & & Fraxinus velutina & 1.19 \\
\hline & & Populus fremontii & 1.19 \\
\hline & & Celtis reticulata & 3.57 \\
\hline
\end{tabular}

\begin{tabular}{|c|c|c|c|}
\hline $\begin{array}{l}\text { Transect } \\
\text { Station }\end{array}$ & Category & Species & Mean density \\
\hline \multirow[t]{31}{*}{8} & Subshrub & Brickellia sp. & 20.16 \\
\hline & & Gutierrezia sarothrae & 20.16 \\
\hline & & Haplopappus laricifolius & 120.96 \\
\hline & & Opuntia engelmannii & 120.96 \\
\hline & & Acacia greggii & 20.16 \\
\hline & & Mimosa biuncifera & 20.16 \\
\hline & & Prosopis velutina & 20.16 \\
\hline & & Fouquieria splendens & 20.16 \\
\hline & & Sideroxylon lanuginosum & 40.32 \\
\hline & Shrub & Unknown species & 12.77 \\
\hline & & Agave palmeri & 12.77 \\
\hline & & Brickellia sp. & 12.77 \\
\hline & & Opuntia engelmannii & 25.55 \\
\hline & & Acacia greggii & 51.09 \\
\hline & & Mimosa biuncifera & 25.55 \\
\hline & & Prosopis velutina & 12.77 \\
\hline & & Quercus arizonica & 12.77 \\
\hline & & Fouquieria splendens & 12.77 \\
\hline & & Nolina microcarpa & 12.77 \\
\hline & & Sideroxylon lanuginosum & 63.86 \\
\hline & Tree & Acacia greggii & 3.17 \\
\hline & & Prosopis velutina & 6.34 \\
\hline & & Quercus arizonica & 6.34 \\
\hline & & Quercus turbinella & 3.17 \\
\hline & & Fouquieria splendens & 25.34 \\
\hline & & Sideroxylon lanuginosum & 15.84 \\
\hline & & Celtis reticulata & 3.17 \\
\hline & Cavity & Quercus arizonica & 5.27 \\
\hline & & Juglans major & 1.76 \\
\hline & & Fraxinus velutina & 8.79 \\
\hline & & Celtis reticulata & 5.27 \\
\hline
\end{tabular}

\section{Appendix F, part 2}

\begin{tabular}{|c|c|c|c|c|c|c|}
\hline \multirow[b]{2}{*}{ Transect } & \multicolumn{2}{|c|}{ Litter } & \multicolumn{2}{|c|}{ Bare Ground } & \multicolumn{2}{|c|}{ Rock } \\
\hline & Mean & $\overline{S D}$ & Mean & $\mathrm{SD}$ & Mean & $\mathrm{SD}$ \\
\hline \multirow[t]{8}{*}{ Butterfield } & 30 & 18.4 & 68 & 18.2 & 1 & 3.1 \\
\hline & 50 & 29.0 & 51 & 30.1 & 4 & 5.0 \\
\hline & 36 & 23.5 & 55 & 22.4 & 11 & 15.0 \\
\hline & 35 & 15.7 & 61 & 16.5 & 7 & 9.2 \\
\hline & 29 & 22.0 & 43 & 18.7 & 27 & 14.9 \\
\hline & 29 & 12.1 & 64 & 18.5 & 6 & 9.4 \\
\hline & 52 & 23.3 & 47 & 22.7 & 3 & 4.7 \\
\hline & 22 & 16.4 & 76 & 16.0 & 6 & 7.6 \\
\hline \multirow[t]{8}{*}{ Siphon Canyon } & 55 & 24.2 & 33 & 19.2 & 9 & 8.8 \\
\hline & 52 & 27.5 & 41 & 24.6 & 7 & 12.3 \\
\hline & 59 & 27.4 & 38 & 20.9 & 4 & 7.5 \\
\hline & 40 & 32.6 & 60 & 32.1 & 1 & 3.1 \\
\hline & 60 & 34.3 & 37 & 31.2 & 5 & 11.0 \\
\hline & 28 & 22.7 & 62 & 24.6 & 8 & 10.7 \\
\hline & 58 & 32.1 & 25 & 24.8 & 16 & 25.0 \\
\hline & 29 & 26.2 & 49 & 33.4 & 22 & 18.2 \\
\hline
\end{tabular}


Appendix G. Most abundant bird species at each transect and season based on data published in Russell and Johnson (1976) and the UA inventory. Relative abundance (RA) estimates from Russell and Johnson are number of individuals per transect kilometer whereas RA estimates for the UA effort are the mean number of individuals per transect station or section, including flyovers and birds seen $>75 \mathrm{~m}$ or $>100 \mathrm{~m}$ from stations or sections, respectively. See methods section for community descriptions. Species in bold-faced type are species that are not found on the corresponding list of the most common species by season. Relative abundance estimates are for showing abundance ranks and cannot be compared between studies because of different methods of data collection.

\begin{tabular}{|c|c|c|c|c|c|}
\hline \multirow[b]{3}{*}{ Community } & \multirow[b]{3}{*}{ Season } & \multicolumn{4}{|c|}{ Study } \\
\hline & & \multicolumn{2}{|l|}{ Russell and Johnson } & \multicolumn{2}{|l|}{ UA } \\
\hline & & Species & $\mathrm{RA}$ & Species & RA \\
\hline \multirow[t]{20}{*}{ Mesquite-grasslands } & Breeding & Gambel's quail & 4.3 & mourning dove & 1.9 \\
\hline & & black-throated sparrow & 2.7 & black-throated sparrow & 1.8 \\
\hline & & canyon towhee & 1.7 & turkey vulture & 1.7 \\
\hline & & cactus wren & 1.3 & canyon towhee & 1.3 \\
\hline & & mourning dove & 0.8 & Gambel's quail & 1.1 \\
\hline & & Mexican jay & 0.6 & white-winged dove & 1.1 \\
\hline & & violet-green swallow & 0.6 & ash-throated flycatcher & 1.1 \\
\hline & & verdin & 0.5 & cactus wren & 1.1 \\
\hline & & Wilson's warbler & 0.5 & Bewick's wren & 1.0 \\
\hline & & western tanager & 0.4 & northern mockingbird & 0.6 \\
\hline & & ash-throated flycatcher. & 0.4 & rufous-crowned sparrow & 0.6 \\
\hline & Non-breeding & chipping sparrow & 11.0 & bushtit & 1.2 \\
\hline & & Brewer's sparrow & 9.9 & chipping sparrow & 1.0 \\
\hline & & black-throated sparrow & 6.0 & western bluebird & 0.8 \\
\hline & & white-crowned sparrow & 3.7 & white-crowned sparrow & 0.7 \\
\hline & & Gambel's quail & 2.6 & bridled titmouse & 0.4 \\
\hline & & canyon towhee & 2.4 & canyon towhee & 0.4 \\
\hline & & dark-eyed junco & 2.4 & phainopepla & 0.3 \\
\hline & & cactus wren & 0.7 & western scrub-jay & 0.3 \\
\hline & & ladder-backed woodpecker & 0.7 & ruby-crowned kinglet & 0.3 \\
\hline \multirow[t]{23}{*}{ Oak-juniper woodland } & Breeding & Gambel's quail & 5.1 & mourning dove & 2.4 \\
\hline & & Mexican jay & 1.7 & black-throated sparrow & 1.5 \\
\hline & & western scrub-jay & 1.5 & Bewick's wren & 1.2 \\
\hline & & mourning dove & 1.5 & ash-throated flycatcher & 0.8 \\
\hline & & cactus wren & 0.7 & canyon towhee & 0.7 \\
\hline & & rufous-crowned sparrow. & 0.7 & Gambel's quail & 0.7 \\
\hline & & Bewick's wren & 0.6 & brown-headed cowbird & 0.6 \\
\hline & & violet-green swallow & 0.6 & northern mockingbird & 0.6 \\
\hline & & northern cardinal & 0.5 & rufous-crowned sparrow & 0.6 \\
\hline & & black-chinned hummingbird & 0.5 & cactus wren & 0.5 \\
\hline & & ash-throated flycatcher & 0.4 & white-winged dove & 0.5 \\
\hline & Non-breeding & Gambel's quail & 5.4 & Gambel's quail & 3.3 \\
\hline & & chipping sparrow & 4.2 & white-crowned sparrow & 2.6 \\
\hline & & white-crowned sparrow & 4.2 & chipping sparrow & 1.2 \\
\hline & & dark-eyed junco & 4.2 & Brewer's sparrow & 0.7 \\
\hline & & Brewer's sparrow & 1.5 & spotted towhee & 0.4 \\
\hline & & western scrub-jay & 1.5 & black-throated sparrow & 0.2 \\
\hline & & mourning dove & 1.0 & ruby-crowned kinglet & 0.2 \\
\hline & & canyon towhee & 0.8 & western scrub-jay & 0.2 \\
\hline & & cactus wren & 0.8 & cactus wren & 0.2 \\
\hline & & ruby-crowned kinglet & 0.8 & canyon towhee & 0.2 \\
\hline & & spotted towhee & 0.6 & crissal thrasher & 0.2 \\
\hline & & Bewick's wren & 0.6 & northern flicker & 0.2 \\
\hline \multirow[t]{2}{*}{ Wash-riparian } & Breeding & black-chinned hummingbird & 5.8 & Gambel's quail & 1.9 \\
\hline & & northern cardinal & 4.6 & white-winged dove & 1.4 \\
\hline
\end{tabular}




\begin{tabular}{|c|c|c|c|c|c|}
\hline \multirow[b]{3}{*}{ Community } & \multirow[b]{3}{*}{ Season } & \multicolumn{4}{|c|}{ Study } \\
\hline & & \multicolumn{2}{|c|}{ Russell and Johnson } & \multicolumn{2}{|l|}{ UA } \\
\hline & & Species & RA & Species & $\mathrm{RA}$ \\
\hline \multirow[t]{7}{*}{ Wash-riparian } & Breeding & mourning dove & 3.6 & northern cardinal & 1.2 \\
\hline & & white-winged dove & 2.8 & mourning dove & 1.1 \\
\hline & & cactus wren & 2.7 & Cassin's kingbird & 0.9 \\
\hline & & Gambel's quail & 2.1 & cactus wren & 0.9 \\
\hline & & canyon towhee & 2.0 & Bewick's wren & 0.8 \\
\hline & & verdin & 1.8 & northern mockingbird & 0.8 \\
\hline & & hooded oriole & 1.8 & canyon towhee & 0.8 \\
\hline \multirow[t]{10}{*}{ Non-breeding } & & northern cardinal & 6.6 & white-crowned sparrow & 3.0 \\
\hline & & chipping sparrow & 6.0 & American robin & 1.8 \\
\hline & & white-crowned sparrow & 5.8 & vesper sparrow & 1.8 \\
\hline & & dark-eyed junco & 5.3 & spotted towhee & 1.8 \\
\hline & & canyon towhee & 3.9 & Brewer's sparrow & 1.7 \\
\hline & & spotted towhee & 3.7 & chipping sparrow & 1.3 \\
\hline & & Brewer's sparrow & 3.5 & canyon towhee & 1.1 \\
\hline & & Gambel's quail & 3.1 & Gambel's quail & 1.1 \\
\hline & & cactus wren & 2.9 & green-tailed towhee & 1.1 \\
\hline & & curved-bill thrasher & 2.0 & western scrub-jay & 1.1 \\
\hline
\end{tabular}


Appendix H. Number of Trailmaster photos and total number of individuals of each species. Data from Herman-Reese (unpublished data), Fort Bowie NHS, 2000-2001.

\begin{tabular}{llcc}
\hline Group & Common name & Number of photographs & Total number of individuals photographed \\
\hline Reptile & western diamond-backed rattlesnake & 1 & 2 \\
\hline Bird & white-winged dove & 1 & 2 \\
\hline & mourning dove & 3 & 3 \\
\hline & greater roadrunner & 1 & 3 \\
\hline & Mexican jay & 1 & 1 \\
\hline & northern mockingbird & 1 & 1 \\
\hline & lark sparrow & 28 & $>55$ \\
\hline & northern cardinal & 1 & 1 \\
\hline & pyrrhuloxia & 3 & 3 \\
\hline & Bullock's oriole & 2 & 4 \\
\hline Mammal & American black bear & 36 & 37 \\
\hline & white-nosed coati & 8 & 9 \\
\hline & ringtail & 2 & 3 \\
\hline striped skunk & & 2 \\
\hline & coyote & 41 & 3 \\
\hline common gray fox & 1 & 43 \\
\hline & mountain lion & 1 & 3 \\
\hline & bobcat & & 2 \\
\hline & rock squirrel & 1 & 2 \\
\hline & mule deer & 17 \\
\hline
\end{tabular}

\begin{tabular}{ll}
$\begin{array}{l}\text { Appendix I. Photographic vouchers } \\
\text { taken by University of Arizona inventory } \\
\text { personnel, Fort Bowie NHS, 2002-2004. }\end{array}$ \\
\hline Group & Common name \\
\hline Reptile & greater earless lizard \\
\hline & Gila monster \\
\hline & green rat snake \\
\hline Bird & common black-hawk \\
\hline & mourning dove \\
\hline & Bell's vireo \\
\hline canyon towhee \\
\hline Ammal & American black bear \\
\hline & white-nosed coati \\
\hline & striped skunk \\
\hline & hooded skunk \\
\hline & feral dog \\
\hline common gray fox \\
\hline mountain lion \\
\hline & bobcat \\
\hline & collared peccary \\
\hline & mule deer \\
\hline
\end{tabular}




\section{2ध 0 जo \\ science for a changing world}

U.S. Geological Survey

Southwest Biological Science Center

2255 N. Gemini Drive

Flagstaff, AZ 86001 